http://kitaibelia.unideb.hu/

ISSN 2064-4507 (Online) • ISSN 1219-9672 (Print)

(C) Department of Botany, University of Debrecen, Hungary

24(1): 16-65.; 2019

DOI: $10.17542 /$ kit.24.16

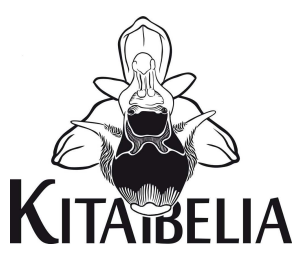

\title{
Adatok a Heves-Borsodi-sík flórájához I. Erdei, erdőssztyepp- és sztyeppfajok elterjedése
}

\author{
SCHMOTZER András \\ Bükki Nemzeti Park Igazgatóság, \\ H-3304, Eger, Sánc u. 6.; schmotzera@bnpi.hu

\section{Data to the flora of Heves-Borsod Plain I.} \\ Distribution of forest, forest steppe and steppe elements
}

\begin{abstract}
This paper reports new floristic data of 159 taxa (158 species and one hybrid) from the Heves-Borsod Plain (5 micro-regions between the Mátra and Bükk Mountains and the Tisza River valley). The data were collected between 1999 and 2018 and supplemented with collected specimen (altogether 93 herbarium sheets). This study is the first part of a thematic series that analyzes the distribution patterns of forest, forest steppe and dry grassland 'steppe' species, beyond reporting floristic data. The data were derived from 51 flora-mapping quadrats (CEU), based on 5.395 field collected data records. Some indicator species of the three species groups have been assessed in detail (with the addition of distribution maps of 25 species). I have also tested two East-West direction 'lines' (the 100-meter isoline and the Csörsz Ditch) for the possible existence of North-South chorological gradients in the area. True forest species (mostly Querco-Fagetea elements) show a dispersed pattern, their representatives can be linked to forest blocks appearing in the landscape. Streams from the adjacented hilly areas (even if they are strongly modified) are very important in the dispersal of the forest species. Their significance and role are decreasing towards the South. For some steppe and forest steppe species (e.g. Brachypodium pinnatum, Campanula bononiensis, Clematis recta, Elymus hispidus, Lychnis viscaria, Ranunculus illyricus, Sanguisorba minor, Stipa spp., Teucrium chamaedrys, Trifolium alpestre, Vinca herbacea) the examined lines indicate a regional area boundary, while for other species (e.g. Phlomis tuberosa, Thalictrum minus) gradient-like distribution differences were not observed. In the distribution of many species an additional southern gradient running along the northern boundary of the former Heves Floodplain was detected. Southwards to this line, the representatives of the selected species are already very sporadic, occurring only in synantropic habitats (e.g. Vincetoxicum hirundinaria).
\end{abstract}

Keywords: chorological gradient, distribution, flora mapping, forest-steppe, Great Plain, habitat fragmentation, vascular flora

Összefoglalás - A cikkben a Heves-Borsodi-sík 5 kistájának területéről 159 taxon (158 faj és egy hibrid) 1999 és 2018 között feltérképezett elterjedési adatait közlöm. A tanulmány egy tematikus sorozat első része, mely az erdei, erdőssztyepp- és száraz gyepekhez köthető sztyeppfajok elterjedési mintázatát elemzi, a florisztikai adatközlésen túl. A kiválasztott, magas indikációs tulajdonsággal bíró, növényföldrajzi szempontból is jelentős fajok esetében lehetséges észak-déli flóragradiensek értékelését is elvégeztem, kiemelten a Csörsz-árok és a 100 méteres izohipsza vonal tekintetében.

Kulcsszavak: Alföld, edényes flóra, elterjedés, erdőssztyepp, élőhely-fragmentáció, flóragrádiens flóratérképezés 


\section{Bevezetés}

A tágabban értelmezett Hevesi-sík területéről 2014-ben egy kisebb flóramonográfiát állítottam össze, amelyben az addigi flóratérképezés eredményeit foglaltam össze, kitérve a terület kutatástörténetére, a növényzet általános leírására és a flóra kvantitatív kiértékelésére is (SCHMOTZER 2014). A kötetben - részben terjedelmi korlátokból is - csak taxonlista került ismertetésre, részletes enumerációt nem adtam. Az ún. primer (nem hálóegység szinten gyűjtött) adatok publikálását jelen cikk-sorozattal kívánom pótolni, melynek első része az 1998 és 2018 közötti időszakból származó erdei, erdőssztyepp- és sztyeppfajokra vonatkozó florisztikai adatokat tartalmazza. A fajok élőhely-preferencia alapján történő elkülönítése mesterséges, de ezt mindig regionális szinten értelmeztem. Így például jelen adatközlés kiterjed olyan domb- és hegyvidékeken gyakori, társulásközömbösként nyilvántartott (BoRHIDI 1995) elemekre (pl. Alliaria petiolata, Geranium robertianum, Lapsana communis stb.), melyek a vizsgált terület jelentős részén „erdőlakónak” tekinthetők. Az erdei fajok többsége Querco-Fagetea faj, amely fajcsoport alföldi regionális elterjedésének értékelését több munka is taglalta más síkvidéki tájakban (lásd például Észak-Alföldön: SIMON 1950, 1951, 1952; Dráva-síkon: KEVEY 2001; Kis-Alföldön: KIRÁLY \& KIRÁLY 2008). Az erdőssztyepp elemek lehatárolása a csoport komplexitása miatt eleve problematikusabb. A kérdéskör újabb feldolgozását KUN \& BöLÖNI (2016) adja. Munkájukban, a klasszikus erdőssztyepp („Waldsteppe”, „Ws”) faj értelmezésen részben túllépve (lásd elsősorban JAKUCS 1961 munkáját), listázták azokat a szárazgyepi fajokat („fénynövényeket”) is, melyek felnyíló koronaszintű erdőssztyepp erdőkben, főleg azok tisztásain is megjelennek. Dolgozatomban az erdőssztyepp fajok lehatárolásakor a szűkebb értelmezést követve, Jakucs már idézett munkáját vettem alapul, azonban a kategórizálást a fajok regionális élőhelypreferenciája és növényföldrajzi jelentősége szerint indokoltnak tartottam módosítani. Ez alapján soroltam az erdőssztyepp-fajok közé az alábbiakat: Campanula bononiensis, Chamaecytisus virescens, Cerasus fruticosa, Polygonatum latifolium, Rosa gallica, Tanacetum corymbosum, Thalictrum minus, Vicia tenuifolia. A dolgozatban elemzett sztyeppfajokat mint szárazgyepi fajokat értelmeztem, többségében ezek Festucetalia valesiacae illetve tágabb élőhelypreferenciájú Festuco-Bromtea fajok (BoRHIDI 1995). KUN \& BöLÖNI (2016) szélesebb erdőssztyepp faj értelmezése alapján, számos képviselőjük besorolható a felnyíló erdők „fénynövényei” közé, azonban itt szárazgyepi fajként értékeltem képviselőiket (pl. Artemisia pontica, Inula germanica, Peucedanum alsaticum, Thlaspi jankae).

A florisztikai adatok jelen közleményben való publikálását több szempontból is fontosnak tartottam:

(1) Egyrészt a Crisicum flórajárásra vonatkozóan számos új florisztikai dolgozat került publikálására az elmúlt években (lásd MoLNÁR 2005, JAKAB 2005, TAKÁCS \& ZSÓLYOMI 2010, TAKÁCS et al. 2013, TAKÁCS et al. 2014b, KoRDA et al. 2017, LUKÁCS et al. 2017). Ezek jó alapot adhatnak a flórajárás szintjén, a fajok elterjedési mintázatának értékelésében. A jelen közleményben értékelt terület Matricum-i kapcsolatai a lehetséges flóragrádiensek elemzését is képezhetik (lásd ScHмотzER 2015). Ezen elemzéseket csak a konkrét lokalitásokon alapuló, ún. primer adatok - azok sűrűsége - alapján készült elterjedési térképek alapján lehet megvalósítani (lásd Schмотzer 2014). Nem szabad figyelmen kívül hagynunk azt a tényezőt sem, hogy az Alföld potenciális vegetáció-rekonstrukciójának alapját alapvetően a megmaradt erdei és erdőssztyepp-fajok feltérképezése segítette (ZólYOMI 1957, 1969, ZólYOMI \& FEKETE 1984, MolnÁR \& Kun 2000, MoLnÁR 2008, FEKETE et al. 2011).

(2) Másrészt, országos lefedettségben, a flóraatlasz (BARTHA et al. 2015) publikálását követően számos florisztikai adatközlő cikk jelent meg, melyek egy „új típusú” adatközlési metódusra alapoznak (lásd például MolNÁR et al. 2016, 2017). Ezek referenciapontként egyedül az atlaszban megjelent hálótérképeket vették alapul, így a korábbi archív irodalmi és herbáriumi 
adatokat figyelmen kívül hagyták. A Közép-Európában és nálunk is nagy hagyományokra visszanyúló florisztikai kutatások ezzel jelentősen leegyszerűsödtek, a publikációk összeállításánál a „novum” megállapításán túl, elmaradtak azon közlések, amelyek az adott faj elterjedésének növényföldrajzi vonatkozásaira, élőhelypreferenciájára vagy akár terjedési tendenciájára vonatkoznának (lásd KIRÁLY \& KIRÁlY (2018) észrevételeit is). Nyilván ezek megadása jóval egyszerűbb egy regionálisan lehatárolt terület florisztikai értékelése esetében, ugyanakkor kiemelt növényföldrajzi jelentőséggel bíró vagy adventív (terjedő) faj esetében ezen információk megadása jogos igényként jelentkezhet. A nagymennyiségű adatközlés mellett csak elszórtan jelennek meg olyan tanulmányok, amelyek a törlendő, helyesbítendő és kétes adatokra vonatkozóan tesznek észrevételeket (lásd például KEVEY 2017, 2018).

(3) Harmadrészt, a 2014. évi összefoglalást követően is folytattam a felméréseket, kiemelt figyelmet szentelve a hegyvidékekről lefutó patakok, illetve az erdőterületek tematikus vizsgálatára. Ezen felmérések az elmúlt 4 évben számos új, értékes adatot szolgáltattak a terület flórájához (pl. Doronicum hungaricum, Listera ovata, Ranunculus illyricus stb.).

Fekete Gábor a florisztikai feltárómunkák és azok dokumentálásának lehetőségeit ekképpen foglalta össze: „El kell fogadni, hogy a puszta adatközlés nem feltétlenül végcél, ugyanakkor alkalmas adathalmaz izgalmas kutatások alapja lehet. A flóra térbeli mintázata kezdettól vizsgálat tárgya, ma is az: új perspektívát nyújtó elméletek, módszerek, újszerú hipotézisek jelentkeznek, amelyek az »új« biotikának új utakat kínálnak bejárásra" (FEKETE 2011). Az egyik ilyen példaként a flóragrádiensek vizsgálatát tekintette. A Duna-Tisza köze esetében is a nagyszámú florisztikai adat tette lehetővé az erdei, erdőssztyepp- és sztyepp-fajok mintázatának értékelését (lásd FEKETE et al. 1999, 2001). Dolgozatomban a primer adatközlésen túl, a lehatárolt fajcsoportok mintázatára alapszintű kiértékelést is tettem a hegylábperem és a Tisza-völgy közötti területen.

\section{Anyag és módszer}

Az enumerációban a sorszámozás és a nevezéktan KIRÁLY (2009) munkáját követi. Az adatok listázása a kistáj, majd a település- és dűlőnév sorrendjében történik, az érintett flóratérképezési negyed-kvadrátok kódjai a lista végén találhatók (lásd NIKLFELD 1971, KIRÁLY 2003). Az online frissülő flóraatlaszra „MFA online” rövidítéssel utalok.

Az adatközlésnél a földrajzi kistáj-lehatárolást vettem alapul (DövÉNYI 2010), melyet a dúlők szintjén finomítottam. Az új kistáj-kataszterben önálló tájként fel nem tüntetett - a Tarna folyó törmelékkúpjaként azonban markánsan elkülönülő - Hevesi-homokhát önálló kistájként történő feltüntetését indokoltnak tartottam. A dűlőnevek megnevezése a Bükki Nemzeti Park Igazgatóság által használt egységes dűlőkatasztert és annak térinformatikai fedvényét követi. A dűlőnevek alapját az M 1:10.000-es méretarányú topográfiai térképek, a külterületi kataszteri térképek, a katonai felmérések térképei és a megyei helységnévtár névanyaga képezte (lásd PELLE 1975, 1980 munkáit).

A terület természetföldrajzi és flórakutatástörténeti bemutatásától itt eltekintek, ezeket a témákat a hivatkozott monográfia részletesen tárgyalja (SCHMOTZER 2014).

A korábbi kiértékelésben szereplő vizsgált területet kibővítettem, annak érdekében, hogy a mintázatok értékeléséhez a Bükkből lefutó patakok teljes szelvényei bekerülhessenek (a vizsgált terület keleti határát így az Eger-patakon keresztül a Tisza-tóba ömlő Kánya-patak képezi). Ez már a Borsodi-Mezőség kistáj keleti részéhez tartozik. Kisebb bővítés történt még a vizsgált terület északi részén, ott a vizsgálati terület határának a 3-as főutat vettem. Néhány, ritka faj esetében a főút északi mezsgyéjén észlelt faj is bekerült az enumerációba. A vizsgált öt kistájjal, illetve kistájrésszel lehatárolt terület (Hevesi-sík, Gyöngyösi-sík, Hevesi-homokhát, Hevesi-ártér, Borsodi-Mezőség) így 1.362 km²-es területet fed le (ez 14\%-os területbővü- 
lést a korábbi vizsgálati területhez képest) (1. ábra). Természetesen a dűlők szintjén történt lehatárolás mesterséges, a kistájak közötti határok átmenetiek, inkább sávként értékelhetők.

Az egyes kiválasztott fajok elterjedésének értékelésekor egyrészt a 100 m tengerszint feletti magasságot jelző szintvonalat (izohipsza) vettem alapul, másrészt vizsgáltam a Csörszárok fő vonalához képest viszonyított elterjedésüket is. Utóbbi esetben GARAM et al. (2003) térképeit vettem figyelembe, annak digitalizált fedvényeit használtam fel. Bár a sáncárok nem minden szakasza ismerhető már fel a terepen, folytonos vonalként digitalizáltam a Csörszárok vonalát. A vizsgálatba olyan fajokat vontam be, melyek legalább tíz lokalitásban előfordulnak a vizsgált területen. Lokalitás alatt minden esetben a dűlőt, mint lekérdezési egységre vonatkozó területegységet értettem.

A közel két évtizedes adatgyűjtés során kézi GPS készülékeket (Garmin eTrex Legend H és HCx, Garmin Geko 201) és terepi adatgyűjtőket (Mio DigiWalker P560, Trimble Juno 3B, Spectra Mobilemapper) használtam, a fajok térinformatikai adatbázisba kerültek tárolásra, rendszerezésre (ArcGIS szoftver környezetben). Az enumerációba bekerült fajok esetén az adat első rögzítésének évét is megadtam. Amennyiben a növényről herbáriumi példánnyal rendelkezem, ezt szintén jeleztem („HB”). Ha a gyüjtés éve nem egyezik meg az első észlelés évszámával, akkor az első évszám után a gyűjtés évét is feltüntettem zárójelben. A lapok magángyüjteményemben találhatók meg (Noszvaj - Eger).

$\mathrm{Az}$ adatok esetében adatközlőt csak azokban az esetekben adtam meg, amelyek nem a szerzőhöz köthetők. Amennyiben a szerző az adott fajt, a megadott lokalitásban ellenőrizte, akkor ezt a tényt az évszám mögött felkiáltójellel [!] jelöltem. A további adatközlők neveit az alábbiakban rövidítettem: Barina Zoltán (BZ), Borbáth Péter (BP), Ferenc Attila (FA), Magos Gábor (MG), Pozsonyi András (PA), Szitta Tamás (SziT), Széles Tamás (SzéT), Táborská Jana (TJ), Tóth László (TL), Urbán László (UL).

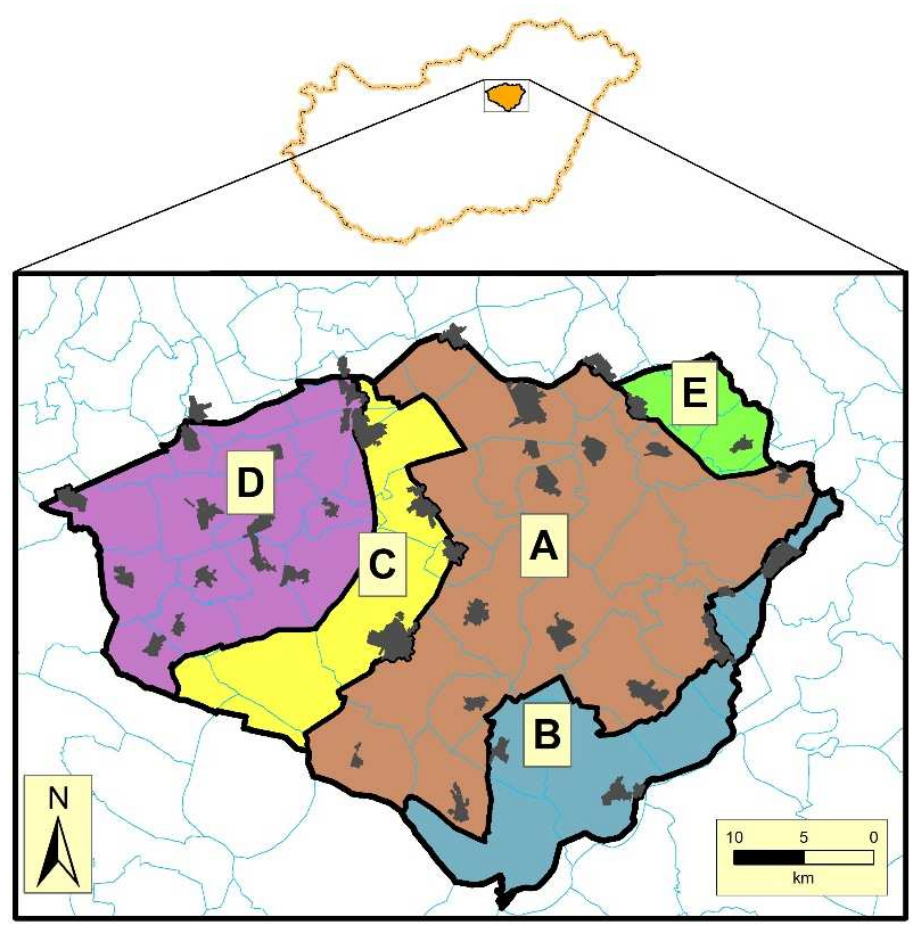

1. ábra A vizsgált területtel érintett kistájak elhelyezkedése A - Hevesi-sík B - Hevesi-ártér C - Hevesi-homokhát D - Gyöngyösi-sík E - Borsodi Mezőség

Fig. 1 The surveyed area with the borders of the microregions A - Heves Plain B - Heves Floodplain C - Heves Sand Region D - Gyöngyös Plain E - Borsodi Mezőség 


\section{Enumeráció}

42. Athyrium filix-femina (L.) Roth: Hevesi-sík - Poroszló: Nagy-állás (2005) [8389.2]. - Majornál, betonkútban egyetlen tő (2005). A határozást egy leszáradt levél alapján Sulyok József erősítette meg. A kút karbantartása miatt a betelepülő állomány megsemmisült. Legközelebbi ismert állománya a Kerecsendi-erdőben (kvadrátazonosító: 8287.2) található a kistáj északi peremén. A Crisicum Tisza-balparti területéről 2 új adat került publikálásra, Tiszaderzsről és Újszentmargitáról (MoLNÁR 2005, LUKÁcs et al. 2017)

55. Dryopteris filix-mas (L.) Schott: Gyöngyösi-sík - Boconád: Kavicsbányák (2018), Tó-nyilas (2003); Hevesi-sík - Mezőtárkány: Tárkányi-erdő (2004); Pély: Makkos-erdő (2002); Újlőrincfalva: Disznókúti-erdő (2017); Hevesi-homok-hát - Tarnaörs: Bíbic-part (2008), Kút-lapos (2004); Borsodi-Mezőség - Egerlövő: Hármas-határ (2017), Lövői-erdő (2017); Mezőszemere: Prónay-erdő (2017) [8289.1], [8289.4], [8387.2], [8387.3], [8388.2], [8389.4], [8486.2], [8487.4] - Kocsányos tölgyes erdőtelepítésekben, olykor telepített erdei fenyvesekben (Tarnaörs, Boconád). A Tiszai-Alföld területén igen szórványos (MFA online), legjelentősebb állományai feltehetőleg a Taktaközben találhatók (TAKÁcS \& ZSÓLYOMI 2010). (3.G. ábra)

56. Dryopteris carthusiana (Vill.) H.P. Fuchs: Hevesi-sík - Pély: Makkos-erdő (2010); Borsodi-Mezőség - Egerlövő: Lövői-erdő (2017) [8289.4], [8487.4]. - Igen sporadikus a vizsgált területen. Telepített kocsányos tölgyesekből került elő (mindkét esetben 1-2 tő). Legközelebbi ismert állománya a Kerecsendi-erdőben található a kistáj északi peremén.

99. Rumex sanguineus L.: Hevesi-sík - Mezőtárkány: Tárkányi-erdő (2017) [8388.2]. - Telepített tölgyesben. A Tiszai-Alföld északi részén igen szórványos előfordulású (pl. Ohat, LUKÁcs et al. 2017). Ismert állománya él a Kerecsendi-erdőben (MFA online).

102. Salix caprea L.: Hevesi-ártér - Tarnaszentmiklós: Kállai-dűlő (1999); Hevesi-sík - Füzesabony: Csurgó-ér-dűlő (2017); Heves: Hevesi-dűlő (2002); Kerecsend: Lógó-part (2004) [8287.2], [8288.4], [8387.4], [8488.1]. - Sporadikus előfordulású, elsősorban anyagnyerőhelyek, kubikgödrök szegélyében fordul elő. A vizsgált területről publikált adata a füzesabonyi Denár-dűlőből ismert (MARSCHALL \& VoJTKó 1989). A Crisicum-i állományok spontaneitása vitatott (lásd MoLNÁR 2005).

116. Alnus glutinosa (L.) Gartn.: Gyöngyösi-sík - Kál: Fabók-ér (2002); Nagyút: Tarnóca (2005); Hevesi-ártér - Kisköre: Tisza-tó-töltése (2009); Sarud: Falualja (2009), Laskó-gát (2009), Tisza-tó-töltése (2009); Tiszanána: Tisza-tó-töltése (2009); Hevesi-sík - Besenyőtelek: Laskó (2017); Erdőtelek: Tarna (2008); Füzesabony: Eger-patak (2003), Laskó - dél (2002), Laskó - észak; Poroszló: Laskó (2017); Tarnaörs: Bíbic-part (FA) (2008); BorsodiMezőség - Borsodivánka: Rima (2017); Szihalom: Rima (2016) [8285.4], [8287.3], [8288.1], [8288.2], [8288.4], [8290.3], [8387.1], [8387.2], [8389.1], [8389.3], [8389.4], [8486.2], [8489.2], [8489.3], [8489.4] - Vízfolyások mellett szórványosan. A Tisza-tó környékén és a vizsgált terület északi részén gyakoribb. Megtelepedő fiatal egyedei többször a „mederrendezési" munkák áldozatává válnak. A puszta belső részéből teljesen hiányzik. BARTHA \& MÁTYÁs (1985) térképe is csak Erdőtelekről jelzi (Erdőtelki égerláp). A faj elterjedési térképét a vizsgált területen - a 2014-ig feltárt lelőhelyekkel - SCHMOTZER (2014) közli.

118. Carpinus betulus L.: Hevesi-sík - Átány: Puky-tag (2003); Hevesi-homok-hát - Kál: Kilencszázas-dűlő (2006); Borsodi-Mezőség - Egerlövő: Eger-csatorna (2017) [8287.4], [8289.4], [8388.1]. - Fasorokban szórványosan telepítve fordul elő, csak nem őshonos előfordulásai ismertek. A Puky-tagnál (Átány) egykori tanyasi iskolaépület helyén felverődött erősen elakácosodó kultúrerdő-foltban fordul elő, más kollin fajok (pl. Arum orientale, Mercurialis perennis) társaságában.

125. Quercus cerris L.: Gyöngyösi-sík - Nagyút: Kis-erdő (2006); Visznek: Határ-fertő (2017); Hevesi-ártér - Sarud: Tisza-tó-töltése (2003); Hevesi-sík - Kömlő: Bogárzói-tábla (2018), 
Dúl-fenék (2017); Mezőtárkány: Nagy-fenék (2018) [8286.4], [8386.1], [8388.4], [8389.1], [8489.2] - Jobbára telepített állományai ismertek a területről. A nagyúti állomány őshonossága - a társuló lágyszárúfajok megléte miatt - feltételezhető. Számos fiatal erdőtelepítés került kivitelezésre a puszta belső részein (pl. Kömlő településhatárban) az elmúlt évtizedben.

151. Thesium ramosum Hayne: Gyöngyösi-sík - Kompolt: Kis-rét (2012); Nagyút: Kis-erdő (2006), Pásztor-szög, Sár-rét (2005), Tarnóca (2006), Válykos (2002); Tarnaméra: Nagyszék (2018); Tarnaörs: Horgas (2017); Tarnazsadány: Tarnóca (2004); Hevesi-ártér - Tarnaszentmiklós: Hanyi-ér (1999); Hevesi-sík - Átány: Hanyi-ér („HB”) (1999), Külső-Szárazbű (2005), Szikes-gyep-dűlő (2002), Telekalja (2007), Tető-halmi-dűlő (2002); Dormánd: Kishíd-mező (2002), Nagy-Hanyi-dűlő (2007), Nagy-Hanyi-puszta (2003); Erdôtelek: Falu-rét (2007), Parlag (2004), Szakállas (2002); Füzesabony: Birinyi-kút (2002), Csörsz-árok (2002), Denár-dúlő („HB”) (2017), Nagy-legelő (2002), Szőlő-hát (2002); Heves: Bika-Nyilas (2018), Császi-mellékcsatorna (2002), Fácános („HB”) (1999), Gazdák-legelője (2002), Radics-tagi-legelő (2002); Hevesvezekény: Hanyi-ér (2008), Hosszú-dűlő (2005); Jászivány: Horváth-dűlő (2004), Papp-dűlő (2009); Kömlő: Csincsa (2002), Peres-alji-erdő (2002); Poroszló: Két út köze (2002), Kis-Fehér-akla (2002); Szihalom: Nagy-réti-dúlő (2002); Hevesihomok-hát - Heves: Bazsó-major (2007); Kál: Első-nyomás (2002); Tarnaörs: Bíbic-lapos (2004); Borsodi-Mezőség - Borsodivánka: Rima (2017); Egerfarmos: Barta-állás (2017); Egerlövô: Eger-csatorna (2017); Mezőszemere: Ostoros-patak (2002); Szihalom: Rima („HB”) (2016) [8190.3], [8286.4], [8287.3], [8287.4], [8288.2], [8288.3], [8288.4], [8289.2], [8289.3], [8289.4], [8290.4], [8386.2], [8386.4], [8387.2], [8387.4], [8388.1], [8388.2], [8388.3], [8388.4], [8389.1], [8486.1], [8486.2], [8487.2], [8487.3], [8487.4], [8488.1], [8488.3]. - Löszgyepekben, regenerálódó parlagokon, csatorna- és töltésoldalakban fordul elő. A vizsgált területen szórványos előfordulású, de közel az összes flóratérképezési kvadrátban előfordul. Az érintkező bükkaljai területrészeken sem ritka (SCHMOTZER 2015, MFA online) Publikált adata a Csörsz-árokról ismert (ZóLYOMI 1969).

153. Thesium linophyllon L.: Hevesi-sík - Erdôttelek: Csörsz-árok (2008); Kerecsend: Lógópart (2007) [8287.2], [8287.4], [8288.1]. - Lelőhelyein félszáraz gyepekben, azok cserjésedő változataiban fordul elö. A nagytájhatárt csak a peremen lépi át a faj.

178. Fallopia dumetorum (L.) Holub: Hevesi-sík - Átány: Egri-út-dűlő (2005); Borsodivánka: Marha-járás (2017); Füzesabony: Belterület /Laskó/ (2002), Laskó - dél (2002); Kerecsend: Lógó-part (2016); Újlőrincfalva: Disznókúti-erdő (2000); Hevesi-homok-hát - Heves: Bírótelep (2015); Kál: Homoki-földek (2002) [8287.2], [8287.4], [8288.4], [8289.4], [8388.3], [8389.4], [8487.1]. - Sövényekben, töltésoldalakban, illetve szórványosan erdőszármazékokban fordul elő. Országosan adathiányos faj (MFA online), a Tiszai-Alföld északi részén különösen szórványos adatokkal rendelkezik. Az érintkező dombvidéki tájakban már gyakorinak tekinthető.

280. Arenaria procera Spreng.: Gyöngyösi-sík - Nagyút: Kis-erdő, Sár-rét (2006); Hevesi-sík - Kerecsend: Lógó-part („HB”) (2016) [8286.4], [8287.2], [8288.1]. - A Laskó és a Bene-patakok teraszain, reliktumjellegú gyepekben fordul elő. Publikált adata ismert a Lógó-partról (SCHMOTZER in VojtKó 2001) és Csörsz-árokról is (ZóLYomi 1969; [8288.3]). Utóbbi helyről nem sikerült előfordulását megerősíteni az elmúlt évtizedekben. A Crisicum területén előfordulása unikális.

283. Moehringia trinervia (L.) Clairv.: Hevesi-sík - Erdőtelek: Arborétum (2004); BorsodiMezőség - Mezőszemere: Prónay-erd”̋ („HB”) (2017) [8289.1], [8387.2]. - Arborétum zárt erdei aljnövényzetében illetve telepített tölgyesben fordul elő. A faj ritkán ereszkedik le a hegységek területéről, a Tiszai-Alföld északi részéről csak a Sajó-völgyből ismert előfordulása (MFA online). 
295. Stellaria holostea L.: Gyöngyösi-sík - Tófalu: Templom-föld (MG) (2016); Borsodi-Mezőség - Mezőszemere: Prónay-erdő („HB”) (2017) [8287.1], [8289.1]. - A vizsgált terület északi részén; Tófalunál községhatárt képező műút cserjés mezsgyéjében, míg a Prónay-erdőben kocsányos tölgyesben, illetve annak nyiladékában fordul elő. A Tiszai-Alföld északi részéről csak a Sajó-völgyből ismert előfordulása (MFA online).

335. Lychnis coronaria (L.) Desr.: Hevesi-homok-hát - Kál: M3-autópálya (2017) [8287.4]. Adventív állománya került elő autópálya felüljáró meredek rézsűjéről. A faj legerősebb állományai az Északi-középhegységben találhatók (Mátra, Tarna-vidék, Bükk), a faj déli terjedése sem elképzelhetetlen. Mint gyakori kerti növény is kivadulhatott (kerti hulladék, komposzt révén). Számos Crisicum-beli előfordul spontaineitása megkérdőjelezhető (lásd pl. Karcagnál MOLNÁR 2005).

336. Lychnis viscaria L.: Hevesi-sík - Erdőtelek: Csörsz-árok (2002); Kerecsend: Lógó-part (2004) [8287.2], [8288.1], [8288.3]. - Sztyeppréten illetve reliktumőrző löszgyepekben. Egykor a Hevesi-erdőben is élt (Kitaibel ap. GomBocz 1945, MolNÁR 2008). A Mezőcsáti-erdőből, homoki erdőmaradványból közölt, Budai Józseftől származó adat is csak a közelmúltban került megerősítésre (TAKÁcs et al. 2013).

339. Silene otites (L.) Wibel: Gyöngyösi-sík - Kál: Csörsz-árok (2002); Hevesi-homok-hát Erdőtelek: Bagoly-lapos („HB”) (2008), Belterület /Vörösmarty M. u./ (2003), Homok-dülő (2008), Rejner-tábla (2008); Kál: Akasztó-part (2002) [8287.4], [8387.2]. - Zavart homoki gyepekben, vasúti mezsgyékben. A vizsgált területen csak a Kál - Erdőtelek közötti homoki területeken fordul elő, ahonnan archív adattal is rendelkezik (Kál mellől - Kitaibel 1813 ap. GoмBоCZ 1945; Hevesi-erdő - Kitaibel ap. MoLNÁR 2008). A Nagy-Alföld homok alapkőzetű területein kívül igen szórványos előfordulású (MFA online). (5.K. ábra).

348. Silene bupleuroides L.: Gyöngyösi-sík - Kál: Csörsz-árok (2003) [8387.1]. - Reliktumjellegű sáncárkon, igen szórványosan (20 tő). A kistájból Kömlőnél jelzi Kitaibel („Infra Kömlő in Hevesiensis Com" Kitaibel ap. KANITZ 1862; kvadrátazonosító: 8488.2). Utóbbi adat nem került megerősítésre, kipusztulása feltételezhető. A Crisicum területén igen szórványos, recens előfordulásait újabban a Nagy-Sárrétről jelezték (Schmotzer in LUKÁcs et al. 2017).

353. Silene nutans L.: Hevesi-sík - Erdőtelek: Csörsz-árok (2008); Kerecsend: Fácános-berek, Lógó-part (2004) [8288.1], [8288.3]. - Akácosodó sánc növényzetében (Erdőtelek) illetve cserjésedő löszgyepben (Kerecsend). Utóbbi állomány szerves összeköttetésben van a Kerecsendi-erdő állományaival (ahol a faj gyakori előfordulású). A Nagy-Alföld középső - jobbára kötött talajú - kistájaiból teljesen hiányzik (MFA online).

355. Cucubalus baccifer L.: Gyöngyösi-sík - Boconád: Köles-föld (2015), Temető-dűlő (2017), Tó-nyilas (2001); Kál: Árnyék-alja-dűlő (2003), Árok-alja (2018), Csörsz-árok (2008), Fabók-ér (2003); Nagyút: Kis-erdő (2006); Hevesi-ártér - Jászkisér: Alsó-sárgakút-dűlő (2017); Kisköre: Homok (2018), Szőlő-part (2018); Pély: Picinges-dűlő (BZ) (2018); Sarud: Tisza-tótöltése (2009); Tarnaszentmiklós: Babócsa (2009), Bólya-erdő (2002), Bukta-gyep (2002); Tiszanána: Vése (2017), Vése-fok környéke (2017); Újlórincfalva: Kis-Domján (2002), Laskógát (2009), Székes-hát (2000); Hevesi-sík - Átány: Kis-kút-dűlő (1999); Besenyőtelek: Gancsos (2005), Laskó-föld (2005), Rátkai-erdő (2000); Dormánd: Csincsa (2018), Két-tanyaközi-tábla (2003); Egerfarmos: Csete-árok (2017), Szentháromság-tábla (2017); Füzesabony: Bozsi-dűlő (2003), Buda-dűlő (2017), Csárda-tető-dűlő (2018), Kis-erdő (2009), Nagy-alsó-dúlő (2005); Heves: Káka (2007); Jászivány: Iványi-erdő (2004), Templom-dűlő (2018); Kömlő: Bíbic-járás (1999), Kis-tanyasi-dúlő (2002), Kocsmáros-fenék (2017); Mezőtárkány: Nagy-fenék (2018), Tárkányi-erdő (2004); Pély: Karámos (2003), Makkos-erdő (1999); Sarud: Kos-legelő (2002); Tenk: Halomi-tábla (2005), Tenki-legelő (2005); Újlőrincfalva: Disznókúti-erdő (2000); Hevesi-homok-hát - Heves: Herceg-dúlő (2018), Kál: Zeleierdeje (2017); Tarnaörs: Bíbic-lapos (2017), Bíbic-part (2017), Kút-lapos (2004); BorsodiMezőség - Borsodivánka: Proletár-dúlő (2017); Egerfarmos: Barta-állás (2002), Farmosi- 
útra-járó-dűlő (2001), Ganéj-szög (2017); Egerlövő: Lövői-erdő (2001); Mezőszemere: Prónay-erdő (2017) [8286.4], [8288.1], [8288.3], [8288.4], [8289.1], [8289.3], [8289.4], [8387.1], [8387.2], [8387.3], [8387.4], [8388.1], [8388.2], [8388.4], [8389.1], [8389.3], [8389.4], [8486.2], [8487.2], [8487.3], [8487.4], [8488.1], [8488.2], [8488.3], [8488.4], [8489.4], [8588.1], [8588.2], [8589.1]. - Változatos élőhelyeken fordul elő: erdőtelepítésekben, üde cserjésekben (ezüstfásokban), árokpartokon, kubikgödrökben szórványos előfordulású a vizsgált területen. Előfordulása legtöbbször kötődik félárnyékos és árnyékos helyekhez, sok esetben erdőlakó faj. Kitaibel feljegyezte a tarnaörsi fácánoskertből (LőKös 2001). A Tiszai-Alföldön is szórványos előfordulású (MFA online), jelen adatsor számos új hálótérképezési szintű adatbővülést jelent. (3.F. ábra).

373. Dianthus pontederae A. Kerner: Hevesi-sík - Átány: Nagy-fertő („HB”) (1999), Viskifertő (1999); Dormánd: Ér-hát („HB”) (2009); Erdốtelek: Csörsz-árok (2002); Jászivány: Horváth-dúlő (2004), Telki-dúlő (2000); Kerecsend: Lógó-part (2004); Pély: Ludas-dűlő (1999), Ludasi-legelő (1999) [8287.2], [8287.4], [8288.1], [8288.3], [8388.1], [8487.3], [8487.4], [8488.1], [8488.3], [8587.3]. - Szikesekből kiemelkedő löszhátakon illetve a terület északi részén (Csörsz-árok, Lógó-part) félszáraz gyepekben szórványosan fordul elő. A Kitaibel által a Hevesi-erdőből jelzett $D$. carthusianorum faj feltehetőleg a $D$. pontederae-val azonosítható (GomBocz 1945, MolNÁR 2008). A Crisicum területén eltérő gyakoriságú a faj, amíg például a Hortobágy vidékén gyakori (MFA online), addig a jelen adatközléssel érintett területen kifejezetten ritkának tekinthető.

376. Dianthus collinus Waldst. et Kit.: Gyöngyösi-sík - Detk: Kis-Tarnóca (2003); Kápolna: Felső-rét (2003), Nagyút: Kis-erdő (2006), Pásztor-szög (SJ, 1997), Sár-rét (2006), Tarnóca (SJ, 1997):; Tarnazsadány: Tarnóca (2004); Hevesi-sík - Füzesabony: Mogyorós (2016); Kerecsend: Lógó-part („HB”) (2004, 2016) [8286.4], [8287.1], [8287.2], [8287.3], [8288.1], [8386.2]. - Sztyeppréteken, töltésoldalakban fordul elő. Erős állománya ismert a Laskó teraszát kísérve (Kerecsend, Füzesabony). A Gyöngyösi-síkon a Tarnóca és a Bene-patakokat kísérő teraszokon, illetve töltésoldalakban hatol dél felé. Jászdózsáról, vasúti mezsgyéből már ALMÁDI (1985) közli. A Tiszai-Alföld belső részeiről teljesen hiányzik a faj (MFA online). (5.E. ábra).

422. Clematis vitalba L.: Gyöngyösi-sík - Boconád: Csárda-lapos (2017), Temető-dűlő (2017), Tó-nyilas (2003); Kál: Borjú-járás (2002); Tarnaméra: Nagy-szék (2018); Tarnaörs: Békástó (2008); Visznek: Gyöngyös-patak (2006); Hevesi-ártér - Poroszló: Belterület /alvégesi- és felvégesi temető/ (2012); Tarnaszentmiklós: Vadász-tanya (2002); Hevesi-sík - Besenyőtelek: Hamarka-csatorna (2017), Laskó (2017), Laskó-föld (2013), Rókalyuk-dủlő (2006), Zsombékos (2009); Erdôtelek: Arborétum (2017), Pásztorok-fertője (2017), Szakállas (2002); Füzesabony: Belterület /Bethlen G. u./ (2002), Csárda-tető-dűlő (2005), Csurgó-érdűlő (2017), Denár-dűlő (2017), Eger-patak (2003), Kis-erdő (2009), Laskó - dél (2002), Laskó - észak (2002); Jászivány: Bútelki-erdő (2017), Iványi-erdő (2017); Kerecsend: Laskó (2004), Nagy-majorsági-dűlő (2005); Mezőtárkány: Darudéllés (2006), Kis-kőkúti-dűlő (2017), Laskó (2017), Nyárjas (2017), Subik (2017), Tárkányi-erdő (2004); Pély: Makkoserdő (2002); Poroszló: Koppó-hát (2017); Szihalom: Kocsordos (2017), Nagy-réti-dúlő (2017), Nyilas (2017), Remisz-erdő (2017), Varjas-erdő (2002); Újlőrincfalva: Belterület /Fő u./ (2017), Rátka-tag (2017); Hevesi-homok-hát - Erk: Nyárfás (2009); Heves: Bíró-telep (2015), Herceg-erdő (2018); Kál: Második-nyomás (2006), Zelei-erdeje (2017); Tarnaörs: Bíbic-lapos (2017), Bíbic-part (2008), Kút-lapos (2004); Tenk: Bercsényi-tag (2002); Borsodi-Mezőség - Borsodivánka: Proletár-dúlő (2017); Egerfarmos: Barta-állás (2017), Rima (2002); Egerlövő: Lövői-erdő (2017), Szentistváni és kövesdi út-köze (2017); Mezőszemere: Nagy-gyep (2002), Ostoros-patak (2002), Parlag (2017), Prónay-erdő (2003)[8287.4], [8288.1], [8288.2], [8288.3], [8288.4], [8289.1], [8289.3], [8289.4], [8386.3], [8386.4], [8387.2], [8387.3], [8387.4], [8388.2], [8389.1], [8389.2], [8389.3], [8389.4], [8486.1], 
[8486.2], [8487.1], [8487.2], [8487.3], [8487.4], [8488.3]. - A faj elsősorban az üde, félárnyékos élőhelyeket preferálja, így regionálisan inkább „erdőlakónak” tekinthető. Változatos élőhelyeket képes benépesíteni: üde erdőket, cserjéseket, mezsgyéket, töltésoldalakat. A lehatárolt területen sporadikus elterjedésű, legjelentősebb terjedési útja a Laskó-patak. A faj hazánkban domb- és hegyvidékeinken általánosan elterjedt, azonban a Nagy-Alföld középső fátlan részein igen sporadikus (BARTHA \& MÁTYÁs 1995, MFA online). Jelen adatközlés hálóegység szintjén is jelentős új adatközlésnek tekinthető a faj szempontjából. (3.E. ábra).

423. Clematis recta L.: Gyöngyösi-sík - Erk: Holt-Tarna (2017); Kál: Árok-alja (2002), Csörszárok (2003); Nagyfüged: Belső-Tarcsa (2009), Tarnóca (2009); Nagyút: Tarnóca (2005), Temetői-táblák (2002); Tarnaörs: Tarna (2018); Tarnazsadány: Tarnóca (2009); Visznek: HoltTarna (2017); Hevesi-sík - Füzesabony: Laskó - dél (2002), Laskó - észak (2009); Kerecsend: Lógó-part (2016) [8286.4], [8287.2], [8287.3], [8288.1], [8288.4], [8386.2], [8386.3], [8387.1], [8486.1]. - Félárnyékos helyeken, reliktumjellegú gyepekben és cserjésekben. A Csörsz-árok rendszerének jellegzetes fajának tekinthető, illetve a kapcsolt vízfolyások mentén is előfordul a területen (Laskó, Tarna, Holt-Tarna, Tarnóca). A Tarna mellől (Tarnaörs) és a Hevesi-erdőből már Kitaibel Pál is jelzi a fajt (Kitaibel ap. LőKÖs 2001, MolNÁR 2008), míg a jászdózsai Pap-erdőből ALmÁDi (1985) közli a faj előfordulását. A Tiszai-Alföld területén unikális jelentőségű, Szolnok környéki két hálóegységből (Jászalsószentgyörgy és Újszász mellől) Molnár Csaba jelzi (MFA online). A Sajó-Hernád-síkon két erdőrefúgiumból ismertek recens előfordulásai (TAKÁcs et al. 2013). A flóratlaszban publikált 8389.1 kvadrátra eső adatom törlendő (C. vitalba-ra vonatkozik). (4.B. ábra).

424. Adonis vernalis L.: Hevesi-sík - Jászivány: Horváth-dűlő (2004), Kerecsend: Lógó-part (1998) [8287.2], [8288.1], [8487.3]. - Unikális előfordulása vált ismertté Jásziványban, ahol szikesekből és mocsárrétekből kiemelkedő löszháton fordul elő kis állománya. Publikált erős állománya ismert a Lógó-partról (Schmotzer in VoJTKó 2001). A faj erősen visszaszorulóban van az alföldi élőhelyein, a Hevesi-homokhátról (Hevesi-erdő) is kipusztult (Kitaibel ap. MOLNÁR 2008, MFA online).

437. Ranunculus illyricus L.: Gyöngyösi-sík - Kápolna: Belterület /temető/ (2012), Epres (2012); Tófalu: Fekete-dűlő (MG) (2016) [8287.1]. - A kápolnai temetőkertben tömegesen fordul elő; a felső (jelenleg is használt) temetőben erős, közel 5.000 töves, míg az alsó (beerdősült) temetőben kisebb, 100 töves állománya él. A temető melletti rontott akácosokban, kökénycserjésekben is előfordul. Tófalu határában műút-mezsgyén fordul elő, további sztyepp- és erdőssztyepp-fajok társaságában. A vizsgált területről, a Hevesi-erdőből, feltehetőleg annak tisztásairól Kitaibel is jelezte (MOLNÁR 2008). Ez az állomány feltehetőleg kipusztult. A Nagy-Alföld területén igen szórványos (MFA online), az állományok jelentős része erősen veszélyeztetett.

450. Ranunculus auricomus L.: Hevesi-sík - Füzesabony: Denár-dűlő (2017); Kerecsend: Lógó-part (2016); Szihalom: Eger-csatorna [8288.1], [8288.4]. - Eger-patak és mellékcsatornái mentén üde mocsárréten, árokparton fordul elő. A Lógó-parton előforduló állomány szerves kapcsolatban van a Kerecsendi-erdőben élő populációval. Ez a jobbára üde lomberdei faj az Alföld középső pusztai részéről szinte teljesen hiányzik (MFA online). Az egykor, a Hevesi-erdőben élő állománya is felszámolódott, innen Kitaibel még gyüjtötte a fajt (JÁvoRKA 1935, Kitaibel in GomBoCz 1945, MoLNÁR 2008).

462. Thalictrum minus L.: Gyöngyösi-sík - Erk: Gulya-járás (2001); Kál: Árnyék-alja-dűlő (2002), Csörsz-árok („HB”) (2003, 2018); Tarnabod: Káli-külső (2003); Tarnaméra: Iskoladúlő (2003), Pusztafogacs (1999); Tarnazsadány: Tarcsai-legelő; Hevesi-sík - Átány: Hanyiér (1999); Dormánd: Ér-hát (1999), Kis-híd-dűlő (2002), Kis-híd-mező (2002), Nagy-Hanyipuszta (2003); Erdôtelek: Bencsik (2007), Csörsz-árok (2002), Kőkert-kispusztai-dúlő (2007), Parlag (2005), Hanyi-ér (2008); Füzesabony: Csörsz-árok (2002); Heves: Apáti és Kiséri út közt (2015), Bika-Nyilas (1999), Fácános (1999), Gazdák-legelője (2002); Hevesve- 
zekény: Hosszú-fertő (1999), Nagy-halom-dúlő (1999), Nyári-járás (2002), Rakottyás (2005); Jászivány: Csukás (BZ) (2008); Horváth-dűlő (2004), Iványi-erdő (2004), Papp-dúlő (1999), Telki-dűlő (2000), Templom-dűlő (1999), Vágó-járás (2004); Kerecsend: Lógó-part (2016), Nagy-majorsági-dűlő (2016); Kömló: Nagy-járás (2002); Mezôtárkány: Laskó (2017), Tepély (2005); Sarud: Fekete-rész (2006); Hevesi-homok-hát - Heves: Bazsó-major (2007), Bercsényi-telep (2007), Sári-tag (2007), Semlyén-dúlő (2014), Szabó-tag (2002), Vesszős (2007); Kál: Akasztó-part (2002), Proletár (2002); Borsodi-Mezőség - Mezőkövesd: Kányapatak (2003) [8287.2], [8287.4], [8288.1], [8288.3], [8288.4], [8289.2 [8386.2], [8386.4], [8387.1], [8387.2], [8387.3], [8387.4], [8388.1], [8388.4], [8389.1], [8389.3], [8487.1], [8487.2], [8487.3], [8487.4], [8488.1], [8488.3]. - Reliktumjellegű löszpusztai gyepekben, határ-mezsgyéken és cserjésekben fordul elő. A számos adat ellenére szórványos előfordulásának értékeljük, mivel elszigetelt állományaik többnyire alacsony példányszámúak és erősen veszélyeztetett határélőhelyekhez (lásd mezsgyék) köthetők. Előfordulási térképe egyben jól kijelöli a területen futó sánc-árok rendszereket (Csörsz-árok, Felső- és Alsó-Kisárok). Állományai erősen pusztulóban. Publikált adata a Hevesi-erdőből (Kitaibel ap. MoLNÁr 2008) és a Csörsz-árok erdőtelki szakaszáról ismert (ZóLYOMI 1969). A Tiszai-Alföldön szórványos előfordulású, számos új adat került publikálásra a Tiszától keletre eső Crisicumi részből (LuKács et al. 2017). (4.H. ábra).

470. Berberis vulgaris L.: Gyöngyösi-sík - Adács: Cinéregyháza (MG) (2016), Csizmaszár (2018); Nagyút: Kis-erdő (2007); Hevesi-sík - Erdőtelek: Szécsényi-lapos (2006); Mezőtárkány: Tárkányi-erdő (2004); Hevesi-homok-hát - Heves: Rózsa-hegy (2006); Borsodi-Mezőség - Egerfarmos: Barta-állás (2006) [8286.4], [8288.3], [8289.3], [8386.1], [8387.2], [8388.2]. - Erdőtelepítések szegélyében, utak mentén igen szórványosan a vizsgált területen (általában 1-2 egyed lokalitásonként). Az Alföldön a Kis-Alföld és a Duna-Tisza köze kivételével igen szórványos, legtöbbször hiányzik (BARTHA \& MÁTYÁs 1995, MFA online).

485. Corydalis cava L.: Hevesi-sík - Besenyőtelek: Vágott-marhajáró-dűlő; Kerecsend: Alsókis-erdő (2016); Mezôtárkány: Legelő [8288.1], [8388.2], [8486.1]. - Kerecsendnél a Lógópart melletti kis akácos erdőfoltban él, míg a puszta középső részén egy - a Rátkai-erdőre kifutó - községhatár-mezsgye két oldalán fordul elő, származékerdők (akácos, illetve amerikai kőrises) alatt. A második lokalitás ősiségét is feltételezzük, itt a megtalálás óta kisebb terjedése is megfigyelhető. A Kerecsendi-erdőből erős állománya ismert (ZóLYOMI 1957, SzUJKó-LACZA 1984). A vizsgált terület közvetlen szomszédságában, a jászdózsai Pap-erdőből ALMÁdi $(1984,1985)$ közölte.

488. Corydalis solida L.: Gyöngyösi-sík - Detk: Tarnóca (2003) [8286.4]. - A Tarnóca-patakot kísérő mezofil cserjés alatt, tápanyaggazdag talajon fordul elő. A vizsgált terület más részein nem észleltük. A Crisicum területéről csak a Sajó-Hernád-síkról Girincsi-erdő; TAKÁCs et al. 2013) és a Fekete-Kőrös ligeterdeiből ismert, utóbbi helyen az előző fajjal kevert állományai élnek (KAPOCSI et al. 1998).

502. Alliaria petiolata (M. Bieb.) Cavara et Grande: Gyöngyösi-sík - Nagyút: Kis-erdő (2006); Tarnaméra: Belterület /temető/ (2015); Hevesi-ártér - Tarnaszentmiklós: Vadász-tanya (2003); Hevesi-sík - Átány: Kázsmán-lapos (2004); Erdôtelek: Csörsz-árki-dúlő (2006); Füzesabony: Csárda-tető-dúlő (2017), Görbe-fertő (2017), Kis-erdő (2017), Laskó - dél (2002), Laskó - észak (2009), Szikszói-telep (2009); Jászivány: Templom-dúlő (2018); Kápolna: Bokros-haraszt (2017); Hevesi-homok-hát - Heves: Herceg-erdő (2007), Herceg-tag (2006); Kál: Kertészház (2017); Borsodi-Mezőség - Mezốkövesd: Kánya-patak (2017); Mezőszemere: Prónay-erdő (2017) [8286.4], [8287.2], [8287.4], [8288.1], [8288.4], [8289.1], [8289.2], [8386.4], [8387.2], [8387.4], [8388.3], [8487.4], [8488.3]. - Erdőtelepítésekben, töltésoldali zavart gyepekben, cserjésekben fordul elő. Elsősorban „erdőlakó fajnak” tekinthető. A kapcsolódó domb- és hegyvidéki területeken és az Alföld jelentős részén (elsősorban a csapadé- 
kosabb északi felében) is gyakori elem, a vizsgált területen azonban igen sporadikus (MFA online). (3.A. ábra).

516. Hesperis tristis L.: Hevesi-sík - Erdôtelek: Csörsz-árok - Bencsik (2002), Szakállas (2007); Kerecsend: Lógó-part („HB”) (2016) [8287.2], [8288.1], [8288.3], [8388.1]. - Reliktumjellegű löszpusztaréteken, pusztai cserjésben fordul elő. A Csörsz-ároknál az érintkező véghasznált nemesnyáras vágásterében is megtelepedett. A Lógó-parton előforduló stabil állomány korábban publikálásra került (Schmotzer in VojTKó 2001). A Hevesi-erdőből már Kitaibel is jelezte (MolNÁR 2008). A Nagy-Alföldön igen ritka előfordulású a faj (MFA online).

547. Arabis glabra (L.) Bernh.: Hevesi-sík - Kerecsend: Lógó-part (2016); Hevesi-homok-hát - Heves: Balázs-tag (2002), Kis-Herceg-tag (2005) [8288.1], [8387.4]. - Másodlagos homoki gyepekben, vasúti mezsgyén fordul elő. A Lógó-parton erdőssztyepp elemekben gazdag cserjésedő löszgyepen fordul elő, szerves kapcsolatot ápolva a Kerecsendi-erdő stabil állományával. Egykor a Hevesi-erdőben is előfordult (Kitaibel in MolnáR 2008). A Mezőcsáti-erdőből ismert recens előfordulása (TAKÁCS et al. 2013). A Nagy-Alföldön igen szórványos, a középső területekről gyakorlatilag hiányzik (MFA online).

569. Draba nemorosa L.: Gyöngyösi-sík - Kál: Borjú-járás (2004); Kápolna: Avas-alja („HB”) (2007), Lövész-gödör (2016), Ugrató-domb (2012); Visznek: Gyöngyös-patak (2004); Hevesi-sík - Heves: Hanyi-ér (1999); Hevesi-homok-hát - Kál: Akasztó-part (2002); Tarnaörs: Szent Anna-kápolna („HB”) (2015) [8287.1], [8287.4], [8386.3], [8486.1], [8488.1]. - Löszpusztaréteken, másodlagos gyepekben, töltésoldalakban és kivételesen kiöregedő lucernásokban fordul elő. Kitaibel ezt a fajt is jelezte a Hevesi-erdőből (Gombocz 1945). A vizsgált kistájak területén szórványos, de ez összefügg a faj relatíve rövid időszakra kiterjedő megfigyelhetőségével is. Az országos sporadikus elterjedése is ezzel függhet össze, feltehetőleg ennél jóval gyakoribb a faj. Az intenzív florisztikai felmérések számos kistájban (lásd: SajóHernád-sík (TAKÁcs et al. 2013) és Bükkalja (SCHмотZER 2015)) eredményeztek jelentős adatbővülést.

589. Thlaspi jankae Kern.: Gyöngyösi-sík - Adács: Belterület /temető/ (2015), Külső-Mérgespatak; Kál: Árok-alja (2002); Kápolna: Agyagos (2007), Alsó-rét (2004), Avas-alja (2007), Avas-oldal (2007), Belterület /temeto, kápolnai csata emlékparkja/ („HB”) $(2012,2015)$, Lövész-gödör („HB”) (2007), Ugrató-domb (2003); Kompolt: Belterület /Deák F. u., Fleischmann u., temető/ (2012), Kis-rét (2012), Majorsági-erdő-dűlő (2012), Tarna (2012), Temető-dűlő (2012); Nagyút: Göböl-major (2012), Gyepi-tábla (2007), Kis-erdő („HB”) (2007), Sár-rét (2007), Sár-rét-lapos (2007); Tarnaörs: Gulya-kút („HB”) (2008, 2013), Radics-halom (2013); Tarnazsadány: Tarcsai-legelő (2018), Tarnóca (2009); Tófalu: Csinált-útra-járó (2016), Fekete-dűlő (2016); Hevesi-sík - Dormánd: Bánom-kert (2006), Ér-hát (2003), Nagy-Hanyi-puszta (2005); Erdôtelek: Bencsik (2003), Falu-rét (2003), Parlag (2003); Füzesabony: Csörsz-árok (1999), Kis-kúti-legelő („HB”) (2009); Kerecsend: Lógó-part („HB”) (1999, 2016); Hevesi-homok-hát - Kápolna: Páskom (2015) [8286.4], [8287.1], [8287.2], [8287.3], [8288.1], [8288.3], [8385.2], [8386.2], [8387.1], [8388.1], [8486.1]. - Löszpusztagyepekben, félszáraz gyepekben, cserjésekben és mezsgyéken fordul elő. Nem ritkák a nagy egyedszámú állományok, különösen Kápolna és Kompolt térségében. A kistájak északi részének több temetőkertjéből is kimutatásra került (Kápolna, Kompolt, Nagyút). Jászdózsa és Tarnaörs térségében régóta ismertek állományaik (BusCHMANN 2013, ALMÁDI 1984, 1985) , melyek részben megerősítésre is kerültek (saját felmérések, illetve Juhász Tibor ex verb.). A kerecsendi Lógó-partról már VoJKTó (1994) is jelezte. A Kál környéki lelőhelyek herbáriumi adatokkal (BP) is dokumentáltak (Lengyel Géza 1928, Bánó Lehel 1948 gyüjtései révén). Sajnos ezek cédulái pontosabb lokalizációt nem tesznek lehetővé, de feltehetőleg a valamelyik jelenleg is meglévő nagy egyedszámú állományban kerültek gyüjtésre. Az Alföldön csak a hegylábperemi területeken fordul elő (SCHмOTZER \& TAKÁCS 2014, MFA online), a korábbi 
Duna-Tisza közi adatok (Fülöpháza) félrehatározás eredményei (vö. SoMLYAY 2009). (5.L. ábra).

635. Hylotelephinum telephinum (L.) H. Ohba subsp. maximum (L.) H. Ohba: Gyöngyösi-sík - Kápolna: Avas-oldal (2007); Hevesi-ártér - Poroszló: Belterület (felvégesi temető) (2012); Hevesi-sík - Erdőtelek: Csörsz-árok (2002), Hevesi-homok-hát - Erdőtelek: Fövény-gödridűlő (2004); Heves: Kapitány-hegy (2003), Kis-Herceg-tag (2005), Semlyén-dűlő (2014) [8287.1], [8287.4], [8288.3], [8387.2], [8387.3], [8387.4], [8389.2]. - Zavart homoki gyepekben, akácligetek szegélyében, illetve erdőssztyepp növényzetben (Csörsz-árok). A poroszlói (felvégesi) ótemetőben szubspontán állománya vált ismertté. A Hevesi-erdőből Kitaibel is már jelezte (GomBocz 1945, MoLNÁR 2006), a hevesi mezsgyéken túlélt állományok ennek maradványának tekinthetők. A Nagy-Alföld nem homok alapkőzetű kistájaiból szinte teljesen hiányzik a faj (MFA online). (4.C. ábra).

654. Ribes uva-crispa L.: Gyöngyösi-sík - Boconád: Tó-nyilas (2001); Hevesi-sík - Kömlö: Kistanyasi-dűlő (2002); Mezôtárkány: Tárkányi-erdő (2000); Hevesi-homok-hát - Heves: Szabó-tag (2002); Borsodi-Mezőség - Mezőszemere: Prónay-erdő (2003) [8289.1], [8387.3], [8387.4], [8388.2], [8488.1]. - Telepített tölgyesekben, ültetvényekben, útszegélyekben. Kollin erdei fajként a vizsgált területen adventív előfordulásúnak tekinthetjük, annak ellenére, hogy a flóraatlasz honos előfordulásúként jelzi az Alföld vizsgált részéről (MFA online). A két nagyobb erdőtömbben (Tárkányi-erdő, Prónay-erdő) több erdei fajjal együtt fordul elő.

685. Rosa gallica L.: Gyöngyösi-sík - Kompolt: Majorsági-rész (2006), Száraz-völgy (2012); Hevesi-ártér - Poroszló: Belterület (felvégesi temető) (2012); Hevesi-sík - Erdőtelek: Csörszárok (2002); Füzesabony: Csörsz-árok (2002), Nagy-rét (2003); Heves: Alsóvárosi-temető (2018); Kömlő: Csincsa (2002); Sarud: Csincsa (2002); Hevesi-homok-hát - Heves: Sári-tag (2007); Borsodi-Mezőség - Egerlövő: Eger-csatorna (2017) [8287.2], [8287.3], [8287.4], [8288.1], [8288.2], [8288.3], [8289.4], [8291.1], [8389.2], [8389.3], [8487.2]. - Elsősorban mezsgyékben, zavart gyepekben fordulnak elő állományai. A Csörsz-árokról (ZóLYOMı 1969) és a Lógó-partról (Schmotzer in VojTKó 2001) publikált adattal rendelkezik (mindkét állomány megerősítésre is került). Kitaibel bártfai útja során Kál mellől jelezte (Kitaibel ap. LőKös 2001). A vizsgált terület északi részén honosnak tekintjük, a homokháton (Heves) és a poroszlói felvégesi temetőben szubspontán előfordulású. A Csincsa csatorna töltésén (Sarud és Kömlő településhatárokban) előforduló állományt is honosnak tekintjük a társuló további erdőssztyepp fajok (pl. Inula germanica) megléte miatt. A Dél-Tiszántúl kivételével ahol szintén jobbára „mezsgyelakó” (lásd CSATHó 2009) - a Nagy-Alföldön igen szórványos előfordulású (lásd MoLNÁR 2005, LUKÁCS et al. 2017, MFA online). (4.G. ábra).

690. Rosa rubiginosa L.: Gyöngyösi-sík - Kál: Árnyék-alja-dűlő; Kápolna: Lövész-gödör; Hevesi-ártér - Kisköre: Mike-part; Pély: Péter-rétje; Sarud: Tisza-tó-töltése; Hevesi-sík - Átány: Nagy-fertő („HB”) (1999), Raglovics-tábla (BZ) (2018); Besenyốtelek: Bíbic-legelő (2006), Rókalyuk-dűlő (2006); Egerfarmos: Eger-csatorna (2017), Szentháromság-tábla (2017); Füzesabony: Csárda-tető-dűlő (2018), Csörsz-árok (2002), Kender-föld (2017), Táborozó (2003); Heves: Bika-Nyilas (2018), Gazdák-legelője (2004), Vitézi-telkek (1999); Hevesvezekény: Kis-Ludas (2009), Ludas (2018), Makkai-gyep (2004); Jászivány: Bútelki-erdő (2017); Kömlő: Bogárzói-tábla (2014), Kácsor-fenék (2002), Kocsmáros-fenék (2002), Kocsordosdűlő (2006); Mezőtárkány: Isten mezeje-dűlő (2010), Nádi-dűlő (2017), Tárkányi-erdő (2017); Pély: Hosszú-fertő-hát (BZ) (2018); János-laposa (2018), Kelemen-dűlő (2018), Kelemen-fertő (2009), Makkos-erdő (2006), Rakottyás-legelő (2009); Tarnaszentmiklós: Ludas-dúlő (2008); Hevesi-homok-hát - Heves: Anna-telep (2007), Forrás-dűlő (2002), Sándor-tag (2002); Borsodi-Mezőség - Egerfarmos: Barta-állás (2001), Farmosi-útra-járó-dúlő (2001), Rima (2017); Egerlövő: Eger-csatorna (2017); Mezőszemere: Baglyas (2002), Ostoros-patak (2002), Parlag (2002), Prónay-erdő (2003), Tökföld (2002) [8287.1], [8288.1], [8288.3], [8288.4], [8289.1], [8289.3], [8387.1], [8387.3], [8387.4], [8388.2], [8388.4], 
[8487.2], [8487.4], [8488.1], [8488.3], [8488.4], [8489.4], [8588.1]. - Változatos élőhelyeken fordul elő a faj - erdőtelepítésekben, azok szegélyeiben, fasorokba, cserjésedő gyepekben, így pl. löszgyepekben, másodlagos (siskanádtippanos) gyepekben, töltésoldalakban él. Számos lokalitása ellenére sporadikusnak tekinthető. Legjelentősebb - nagyobb egyedszámmal is bíró - állományaik három jelentősebb gócpont körül sűrűsödnek: (1) Egerfarmos - Mezőszemere; (2) Kömlő - Átány és (3) Pély - Hevesvezekény térsége. A Hevesi-homokháton és a Gyöngyösi-síkon jóval szórványosabb előfordulású. Az egész NagyAlföldön szórványos előfordulásúnak jelzik (MFA online), de ez inkább adathiányra vezethető vissza (lásd LuKÁcs et al. (2017) és TAKÁCS et al. (2014) a faj gyakoriságára vonatkozó észrevételeit a Crisicum északi részére vonatkoztatva).

712. Sanguisorba minor Scop.: Gyöngyösi-sík - Karácsond: M3-autópálya (2010); Kompolt: Kistérpuszta (2005); Nagyút: Cibik-féle-dúlő (2005), Válykos (2002) [8286.4], [8287.3]. - A vizsgált területről csak másodlagos élőhelyekről került kimutatásra (árokpartok, autópálya felhajtó, dűlőút hidja), ami adventív előfordulásra utal. Annak ellenére, hogy a faj a dombvidéki részeken gyakori, igen szórványosan ereszkedik le a Nagy-Alföldre (leggyakoribb a Duna-Tisza közén; SzUjKó-LACZA et al. 1982, MFA online).

730. Potentilla recta L.: Gyöngyösi-sík - Adács: Belterület (temető) (2015); Kompolt: Belterület (temető) (2012); Nagyút: Külső-tag (2006), Válykos (2002); Tarnazsadány: Nagy-Göbölyjárás (2005), Vas-tábla (2004); Hevesi-sík - Besenyőtelek: Laskó-föld (2013); Kerecsend: Lógó-part (2004); Poroszló: Laskó (2005); Hevesi-homok-hát - Kál: Belterület (vasútállomás) (2003)[8286.4], [8287.2], [8287.3], [8287.4], [8385.2], [8386.2], [8387.1], [8389.1], [8587.3], [8687.1]. - Zavart gyepekben, mezsgyéken, töltésoldalakban fordul elő, de megjelenik temetőkertekben is. A vizsgált területen igen szórványosan mutatkozik. A Nagy-Alföldön az Északi-középhegység előterében ritkább előfordulású, mint a Dél-Tiszántúlon (JAKAB 2005) illetve a Nagykunságban (MFA online).

731. Potentilla heptaphylla L.: Gyöngyösi-sík - Erk: Belterület (temető) („HB”) (2015); Kápolna: Ugrató-domb (2012); Hevesi-sík - Kerecsend: Lógó-part (2016) [8287.1], [8287.2], [8386.3]. - A Tarna és a Laskó patakok teraszán kialakult löszös gyepekből, valamint Erknél - a Kis-Tarna feletti magaslaton kialakított - temetőkertből vált ismertté előfordulása. A pusztai tájban a következő faj helyettesíti.

732. Potentilla patula Waldst. et Kit.: Gyöngyösi-sík - Erk: Gulya-járás (2006); Jászdózsa: Gyep-horgas; Kál: Árok-alja (2002); Kápolna: Lövész-gödör (2012); Kompolt: Kis-rét (2012); Nagyút: Birka-legelő (2006), Göböl-járás (2002), Pásztor-szög („HB”) (2005); Tarnaméra: Hosszú-telek (2003), Iskola-dúlő (2003), Pusztafogacs („HB”) (2006); Tarnaörs: Rajna-dúlő (2008); Tarnazsadány: Debrei („HB”) (2018), Tarcsai-legelő (2018); Hevesi-ártér - Kisköre: Nagy-kút-dűlő (2002); Pély: Picinges-legelő (2004); Poroszló: Sárádi-legelő (2004); Hevesisík - Átány: Csohános (2004), Györky-gyep („HB”) (1999), Nagy-fertő (2006), Viski-fertő (1999); Besenyőtelek: Bíbic-legelő (2003); Dormánd: Nagy-Hanyi-dúlő (2007), Nagy-Hanyipuszta (2005); Erdôtelek: Bencsik (2003), Falu-rét (2008), Parlag (2004), Szécsényi-tábla (2008), Hanyi-ér (2007); Heves: Bika-Nyilas (2018), Fácános (1999), Nagy-gyep (2018); Hevesvezekény: Görbe-éri-csatorna („HB”) (1999), Hanyi-ér (1999), Lenke-állás (2002); Jászivány: Pélyi-dűlő (2000), Templom-dűlő (1999); Kömlő: Balog-halom-dűlő (2005), Körei-föld (2005); Pély: Ludasi-legelő (BZ) (2018), Tag-dűlő (BZ) (2018); Poroszló: Akasztó-domb (2004), Benke-rét (2004), Csorda-legelő (2005), Gyalog-legelő (2004), Két út köze (2002), Nagy-Fehér akla (2005); Tarnaszentmiklós: Balog-halom-fertő (2002), Bogárzó-hát (BZ) (2018); Görbe-éri-csatorna (1999); Újlőrincfalva: Földesgazdák-legelője (2018) [8286.4], [8287.1], [8287.3], [8288.3], [8386.2], [8386.4], [8387.1], [8388.1], [8388.2], [8389.1], [8389.2], [8389.3], [8389.4], [8390.1], [8486.1], [8486.2], [8487.4], [8488.1], [8488.3], [8587.2]. - Elsősorban szikesekből kiemelkedő löszgyepekben fordul elő, de szórványosan árokpartokon, csatornatöltéseken is előfordul. A vizsgált kistájak - kötött talajú részeinek - 
jellemző faja, az országos elterjedés dokumentált része is jobbára ide esik (MFA online). Újabb adatokat a Crisicum-ra vonatkozóan Molnár Csaba (Mezőkövesd; MoLnÁR et al. 2017) és Takács Attila (Hejőbába, Nemesbikk; TAKács et al. 2015) közöl. (5.G. ábra).

817. Padus avium Mill.: Gyöngyösi-sík - Kál: Fabók-ér (2002); Hevesi-sík - Erdôtelek: Fácános (2002); Mezôtárkány: Tárkányi-erdő (2009); Szihalom: Varjas-erdő (2002); Hevesi-homokhát - Erdőtelek: Belterület /Benes-kúria/ (2003); Kál: Kilencszázas-dűlő (2006); BorsodiMezőség - Borsodivánka: Köves-dűlő (2017), Nagy-ugar (2017), Proletár-dűlő (2017); Egerlövő: Eger-csatorna (2017), Lövői-erdő (2017) [8287.4], [8288.2], [8289.4], [8387.1], [8387.2], [8388.2]. - Változatos élőhelyeken fordul elő: égerligetekben (erdőtelki „égerláp”, káli Fabók-ér), telepített tölgyesekben (Tárkányi-erdő, Lövői-erdő, Tiszanána), amerikai kőrises erdőfoltban (Szihalom) kastélykertben (Erdőtelek) és fasorokban. Az üde természetszerű erdőkben való őshonossága valószínűsíthető. Soó (1973) ezt megkérdőjelezi, de BARTHA \& MÁTYÁS (1995) térképén a síkvidéki állományokat is honosként tünteti fel. A Borsodi-Mezőség érintett nyugati részéről - elsősorban az Eger-patak mellől - több új lokalitás vált ismertté 2017-ben.

824. Amygdalus nana L.: Gyöngyösi-sík - Tarnaméra: Pusztafogacs - Tó-fenék (2003); $\underline{\mathrm{He}-}$ vesi-sík - Füzesabony: Szikszói-berek (2003); Hevesi-homok-hát - Heves: Bank (2007), Sárga-puszta (2007), Vesszős (2007); [8288.1], [8386.4], [8387.3], [8487.1]. - Elsősorban kivadult (lásd Tarnaméra egykori tanyasi temetője) és telepített állományai (lásd Füzesabony - 31-es főút mezsgyéje) kerültek térképezésre. A hevesi homokháton mezsgyéken fordul elő a faj, több esetben más erdőssztyepp maradványokkal. Őshonosságának ellentmond, hogy Kitaibel Pál a vizsgált területről - így az egykori Hevesi-erdőből - sem jelzi (GoMBocz 1945, MOLNÁR 2008).

839. Chamaecytisus virescens (Kovács ex Neilr.) Dostál: Hevesi-sík - Erdôtelek: Csörsz-árok („HB”) $(2002,2005)$ [8288.3]. - Sánc-árok reliktum gyepjében és ennek cserjésedő állományaiból ismert (erős, több százas állomány, cca. 600 méteres szakaszt felölelve). A Zólyomi által innen Ch. albus-ként közölt állományt (ZóLYomi 1969, Soó 1973) - közös terepbejárást és gyűjtést követően - Pifkó Dániel Ch. virescens-ként azonosította (BP). Kitaibel bártfai kutatóútján Mezőkövesd és Kál között feljegyzett Ch. austriacus észlelés is erre a fajra - és talán erre a lelőhelyre - vonatkozhat (LőKös 2001, PIFKó 2007). A faj elterjedési térképét a vizsgált területen SCHмотZER (2014) közli.

869. Astragalus glycyphyllos L.: Gyöngyösi-sík - Kápolna: Lövész-gödör (2012), Ugratódomb (2008); Nagyfüged: Bene-patak (2004); Hevesi-ártér - Sarud: Tisza-tó-töltése (2003); Tiszanána: Sarud-Saj-foki-főcsatorna (2009); Hevesi-sík - Besenyőtelek: Rátkai-erdő (2000); Borsodivánka: Marha-járás (2017); Füzesabony: Csárda-tető-dúlő (2017); Heves: Alsóvárositemető (2018); Kerecsend: Fácános-berek (2005), Lógó-part (2016); Sarud: Nánai úti dủlő (2013); Szihalom: Kocsordos (2002); Tiszanána: Zsutai-dűlő (2005); Hevesi-homok-hát Heves: Belterület /alsóvárosi temető; Vesszős u./, Káli-dűlő, Klapka-dúlő [8287.1], [8287.2], [8288.1], [8288.4], [8289.4], [8386.2], [8387.3], [8389.3], [8487.2], [8488.2], [8489.1], [8489.2] - Vonalas objektumokat (dűlő- és müutak, árokpartok, töltésoldalak) kísérve fordulnak elő kis egyedszámú állományaik. Egy-egy ponton erdőből (Besenyőtelek: Rátkaierdő) és ótemetőből (Heves) is előkerült a faj. Kitaibel az azóta elpusztult Hevesi-erdőből jelezte (GomBocz 1945, MoLNÁR 2008). Mint félüde és részben erdei élőhelyek faja az Alföldön sporadikus előfordulású (MFA online).

870. Astragalus cicer L.: Gyöngyösi-sík - Adács: Gyanda-szög (2004); Boconád: Bodi-határ (2018), Csárdai gyep (2017), Csárda-lapos („HB”) (2017), Káposztás (2017), Két-legelő-közt (2003), Köles-föld (2015), Magtár környéke (2003), Messzelátó (2003), Nagy-legelő (2003), Porta-nyilas (2015), Szi-lapos („HB”) (2018), Tó-nyilas (2003); Erk: Gosztonyi-föld (2006), Járás-dűlő (2003); Kál: Árnyék-alja-dúlő (2003), Csörsz-árok (2018), Réti-földek (2018); Kompolt: Kis-rét (2003), Nagy-legelő (2003), Tarna (2012), Tarna-közti-dűlő (2018); Ká- 
polna: Alsó-rét (2008), Epres (2008), Lövész-gödör (2012), Szél-tó (2008), Tarna (2008), Ugrató-domb (2012); Nagyfüged: Bene-patak (2004), Kertészeti (2004); Nagyút: Cibik-féledúlő (2005); Tarnabod: Kert-alja (2018); Tarnaméra: Borjú-járó (2003), Hosszú-telek (2003), Kivételesek (2018); Tarnaörs: Cenduláris (2017), Páskom (2017); Tarnazsadány: Páli-berek (2008), Tarnóca (2004); Visznek: Csörsz-árok (2004), Gyöngyös-patak (2004), Külső-Mérges-patak (2004), Nagy-legelő (2017), Tarna (2006); Hevesi-ártér - Sarud: Laskógát (2009); Tarnaszentmiklós: Hanyi-ér (2017); Újlőrincfalva: Laskó-gát (2009); Hevesi-sík - Átány: Egri-út-dűlő (2005), Felső-Szárazbű (2004), Györky-gyep (1999), Hanyi-ér (1999), Kázsmán-tető (2014), Külső-Szárazbű (2005), Nagy-halom laposa (2005), Szárazbű (2001), Szikes-gyep-dűlő (2014), Telekalja (2007); Besenyôtelek: Bíbic-legelő (2006), Csincsa-csatorna (2004), Dormándi Nagy-állás (2018), Tepély-puszta (2013); Dormánd: Belterület /TSz bekötőút/ (2002), Buda-hát (2003), Kápolna melletti-dúlő (2003), Kis-Hanyi-puszta (2006), Nagy-Hanyi-puszta (2006); Egerfarmos: Csete-árok (2017), Eger-csatorna (2017), Ganéjszög (2017), Kákás-tó (2002), Közlegelő (2017), Nagy-zug (2017), Szentháromság-tábla (2017), Vasút-menti (2014), Vízközi-tábla (2014), Zsidó-föld („HB”) (2014); Erdőtelek: Fácános (2003), Falu-rét (2002), Fekete-majorság (2006), Felső-teleki-puszta (2006), Parlag (2005), Pásztorok-fertője (2017), Tarna (2003); Füzesabony: Belterület /Laskó/ (2002), Birinyi-kút (2002), Bozsi-dűlő (2003), Buda (2017), Buda-dúlő (2017), Csárda-tető-dúlő (2017), Csörsz-árok (2008), Denár-dűlő („HB”) (2003, 2017), Eger-csatorna (2003), Egerpatak (2003), Kis-kúti-legelő (2009), Laskó - dél (2002), Laskó - észak (2003), M3-autópálya (2017), Mocsolya-szög (2017), Nagy-legelő (2005), Nagy-rét (2003), Szikszói-berek (2006), Szikszói-telep (2009), Táborozó (2003); Heves: Alsóvárosi-temető (2018), Cseplye (2007), Dobó-tag (2002), Fácános-tanya (2007), Nagy-Dobó-tag (2005), Nagy-lineáris (2006), Nyilas (2004), Radics-tagi (2002), Radics-tagi-legelő (2002); Hevesvezekény: Hanyiér (2002), Hosszú-dúlő (2005), Lenke-állás (2005), Lukács-földek (2002), Nagy-halom-dúlő (1999), Nyári-járás (2002), Seres-dűlő (2005), Szög-határ-dűlő (BZ) (2018), Vörös-kút-hát (BZ) (2018); Jászivány: Papp-dűlő (1999); Kerecsend: Laskó (2005), Lógó-part (2016), Nagymajorsági-dűlő (2005); Kömlő: Szövetkezeti-földek (2002); Mezőszemere: Szihalmi-úti-dûlő (2014), Temető-alja (2006); Mezôtárkány: Belterület /Laskó/ (2017), Eger-csatorna (2006), Kis-kőkúti-dűlő (2006), Laskó (2017), Nádi-dűlő (2017), Nagy-fekete-fertő (2004), Nyárjas (2018), Subik (2017), Verem-hát-dűlő (2006); Poroszló: Farmosi útra-járó (2018), Felső-rét (2006), Két út köze (2002), Közös-kút-lapos (2005), Rátka (2003); Sarud: Belterület /temető/ (2003), Nánai úti dűlő (2003), Öreg-Laskó (2004); Szihalom: Eger-csatorna (2017), Kocsordos (2017), Töviski (3-as főút mezsgyéje) (2003); Tenk: Bíbices (2005), Hegyes-föld (2005), Tenki-legelő (2004), Tenki-puszta (2005); Hevesi-homok-hát - Erk: Nyárfás (2009); Heves: Belterület /Május 1. u./ („HB”) (2007), Bőr-híd (2018), Hevesi határra járó (2008), Sándor-tag (2002), Szabó-tag (2002), Szántai-járás (2002); Tenk: Bercsényi-tag (2002), Kender-áztató (2005), Kis-kút-dúlő („HB”) (2002), Rihes-tó (2002); Borsodi-Mezőség - Borsodivánka: Rima (2017); Egerfarmos: Barta-állás („HB”) (2017), Farmosi-útra-járó-dűlő (2017), Rima (2002); Egerlövő: Eger-csatorna („HB”) (2017), Kánya-patak (2017), Lövőii-erdő (2001), Nagy-állás (2006); Mezőszemere: Szihalmi-úti-dűlő (2014); Szihalom: Rima (2016) [8286.4], [8287.1], [8287.3], [8287.4], [8288.1], [8288.2], [8288.3], [8288.4], [8289.1], [8289.3], [8289.4], [8290.3], [8386.1], [8386.2], [8386.3], [8386.4], [8387.1], [8387.2], [8387.3], [8387.4], [8388.1], [8388.2], [8388.3], [8388.4], [8389.1], [8389.2], [8389.3], [8389.4], [8486.1], [8486.2], [8487.1], [8487.2], [8487.4], [8488.1], [8488.2], [8488.3], [8489.1], [8489.2]. - Vízfolyások mentén töltésoldalakban, zavart és löszös gyepekben, szórványosan erdőszegélyekben. Erősen társulásközömbös jelleget ölt a vizsgált területen. A faj elterjedési térképét a vizsgált területen - a 2014-ig feltárt lelőhelyekkel - SCHмOTZER (2014) közli. Az adatközlést az indokolja, hogy az Alföld középső része felé a korábbi egységes elterjedés felszakadozik, a faj sporadikussá válik, egyes tájakból adathiányos (MFA online). 
897. Vicia tenuifolia Roth: Gyöngyösi-sík - Adács: Telek-dűlő (2017); Kál: Csörsz-árok (2003); Kápolna: Avas-oldal (2007), Lövész-gödör (2012); Hevesi-sík - Erdőtelek: Csörszárok (2002); Füzesabony: Bozsi-dúlő (2017), Szikszói-berek („HB”) (2007); Kápolna: Bokros-haraszt (2017); Kerecsend: Lógó-part (2004), Nagy-majorsági-dúlő (2005); Borsodi-Mezőség - Egerfarmos: Barta-állás („HB”) (2017) [8189.3] [8287.1], [8287.2], [8287.4], [8288.1], [8288.2], [8386.1], [8387.1]. - Cserjés mezsgyékben, ritkán löszgyepekben szórványos előfordulású a vizsgált terület északi szegélyében. A Csörsz-árok vonalát dél felé nem lépi át (közölt elterjedési térkép - SCHMOTZER 2014). Tipikus erdőssztyepp-fajként csak szórványosan jelenik meg a síkvidéken (MFA online). (4.I. ábra).

921. Lathyrus sylvestris L:: Gyöngyösi-sík - Kompolt: Temető-dúlő (2003); [8287.3]. - Dűlőút gyomos mezsgyéjében, cserjékre felkapaszkodva került elő egyetlen állománya 2003-ban. Az Északi-középhegységben a legerősebb állományai a Mátrában találhatók, a betelepülés innen következhetett be. Régi irodalmi adata van Mezőkeresztesről a vizsgált területtől keletre (BUDAI 1914; kvadrátazonosító: 8189.4), illetve a Hortobágy térségéből is jelezték (MOLNÁR 2005).

922. Lathyrus latifolius L.: Gyöngyösi-sík - Kál: Csörsz-árok (2003), Tarnazsadány: Tarcsailegelő (2018); Hevesi-sík - Füzesabony: Buda (2017), Denár-dűlő (2003), Mocsolya-szög (2003); Heves: Apáti és Kiséri út közt („HB”) (2015), Nagy-gyep (1999); Jászivány: Pélyi-dúlő (2004); Kerecsend: Lógó-part (2004) [8287.2], [8288.1], [8288.4], [8386.2], [8387.1], [8487.2], [8487.3], [8487.4]. - Elsősorban reliktumjellegú mezsgyékben (Csörsz-árok, megyehatárdűlő /Heves-Jászivány) fordul elő, de Füzesabony térségében másodlagos csatornaperemeken és siskásodó gyepekben is előfordul. Hevesnél homoki nemesnyáras szegélyében él, mely talán a Kitaibel által 1796-ban Csász-pusztáról jelzett állomány maradványának is tekinthető (Goмвосz 1945). Jellemző erdőssztyepp-faj, az alföldi területeken igen megritkult (MFA online). (4.D. ábra).

973. Trifolium alpestre L.: Gyöngyösi-sík - Kál: Csörsz-árok (2008); Hevesi-sík - Erdôtelek: Csörsz-árok (2002); Füzesabony: Csörsz-árok (2002); Kerecsend: Lógó-part (2004) [8287.2], [8287.4], [8288.1], [8288.3]. - Kizárólag reliktumjellegű gyepekben, a Laskó teraszán és a Csörsz-árok területén (utóbbi helyen molyhos tölgyek alatt is). Erdőssztyepp-fajként a Tiszai-Alföldre jobbára csak tájhatáron lép (Bihari-sík, Hajdúhát és Hevesi-sík; MFA online).

975. Trifolium ochroleucon Huds.: Gyöngyösi-sík - Nagyút: Kis-erdő („HB”) (2006), M3-autópálya (2006); Hevesi-sík - Kerecsend: Lógó-part (HB) (2004) [8286.4], [8287.2]. - A Bene és a Laskó patakok teraszának reliktumjellegű löszgyepjeiben fordul elő, azok cserjésedő (Kerecsend) illetve erdősülő (ludasi Kis-erdő) részein. Másodlagosan autópálya útszegélybe betelepülve is előfordul andezit murvakövön. A Crisicum északi részéről szinte teljesen hiányzik a faj, Törökszentmiklósról hálótérképezési adat szerepel (Horváth Dénes in MFA online). Az érintkező mátraaljai részekről (Feldebrő, Visonta) újabb adatokat Molnár Csaba közöl (MolNÁR et al. 2016). A Bükkalján - főleg mészmentes talajon - sem tekinthető ritkának (SCHMOTZER 2015).

977. Trifolium medium L.: Gyöngyösi-sík - Detk: Kis-Haraszti-dűlő (2009), Tarnóca-dűlő („HB”) (2004); Kápolna: Kígyós-ér (2012); Kompolt: Kígyós-ér (2003); Nagyút: Két-út-közidúlő (2006), Külső-tag (2006), Temetői-táblák (2005); Hevesi-sík - Átány: Görbe-ér (2005), Györky-gyep (2005), Külső-Szárazbű (2005); Erdôtelek: Csörsz-árok (2008), Száraz-rét (2003); Kerecsend: Lógó-part („HB”) (2016); Hevesi-homok-hát - Heves: Forrás-dúlő (2002) [8286.4], [8287.2], [8287.3], [8287.4], [8288.1], [8288.3], [8387.4], [8388.2]. - Csatornapartokon, árkokat, utakat kísérve fordul elő legtöbbször. Szórványosan előfordul löszgyepekben (Kerecsend) és degradált mocsárréteken (Kompolt: Száraz-völgy, Erdőtelek: Száraz-rét) is. Hevesnél spontán cserjésedő kubikgödör szegélyében él (ez egyben a legdélibb előfordulás a vizsgált területen). A vizsgált területen kizárólag a ssp. medium él. A Tiszai-Alföld északi 
területeit (Nyírség, Szatmár-Beregi-sík) kivéve igen sporadikus előfordulású a faj a síkvidéken (MFA online).

984. Dorycnium herbaceum Vill.: Gyöngyösi-sík - Detk: Tarnóca-dűlő (3-as főút) (2004); Hevesi-ártér - Jászkisér: Határ-dűlő („HB”) (2017); Pély: Téglaégető („HB”) (2015) [8286.4], [8587.2], [8588.1]. - Szünanatróp élőhelyekre betelepedve fordul elő a vizsgált területen. Útépítéshez használt - feltehetőleg mátrai eredetű - andezitmurván telepedtek meg kis egyedszámú állományai (Detk határában). Jászkisérnél és Pélynél hasonló szituációban, a vésztározó töltéséhez használt anyaggal hurcolhatták be. A Crisicum területén csak Hajdúságból és a Bihari-síkról ismertek hálótérképezési adatai (MFA online).

985. Dorycnium germanicum (Gremli) Rikli: Gyöngyösi-sík - Nagyút: M3-autópálya („HB”) (2006), Sár-rét-part (2006) [8286.4]. - Megjelenését a társfajhoz hasonló körülmények tették lehetővé (andezi kőmurvával való behurcolás). A Crisicum területéről recens adattal nem rendelkezik (MFA online). Itt a Matricum-i tájhatár déli szegélyén fordul elő.

1007. Geranium robertianum L.: Hevesi-ártér - Kisköre: Homok (2018); Hevesi-sík - Erdótelek: Arborétum (2003), Fácános (2002); Füzesabony: Csárda-tető-dúlő (2018), Nagy-alsódűlő (2005); Kerecsend: Lógó-part (2016); Hevesi-homok-hát - Heves: Herceg-erdő (2018); Tarnaörs: Kút-lapos (2004); Borsodi-Mezőség - Egerlövő: Lövői-erdő (2017); Mezőszemere: Prónay-erdő (2017) [8287.2], [8288.1], [8288.4], [8289.1], [8289.4], [8387.2], [8387.4], [8486.2]. - Erdőültetvényekben, többnyire üde, árnyas helyeken (telepített tölgyesek és nemes nyárasok). Ez a dombvidéken, többféle élőhelyet is benépesítő faj a vizsgált területen „erdőlakóvá” válik. A Crisicum északi peremzónájában és középső részén igen szórványos előfordulású (MFA online).

1034. Linum austriacum L.: Gyöngyösi-sík - Visznek: Nagy-legelő, Sós-kút-gyep (2017) [8386.3]. - Zavart löszgyep cserjésedő szegélyében (50 tő). A Crisicum területén szórványos, illetve részben adathiányos. A flórajárásra vonatkozó archív adatok összegzését, két új előfordulás közlésével LuKÁcs et al. (2017) ismertetik.

1038. Mercurialis perennis L.: Hevesi-sík - Átány: Puky-tag (2003) [8388.1]. - Egykori tanyasi iskolaépület helyén felverődött erősen elakácosodó kultúrerdőfoltban fordul elő, más kollin fajok (pl. Arum orientale, Carpinus betulus) társaságában. A honossága így megkérdőjelezhető. A Tiszai-Alföldön igen szórványosan fordul elő, a flóraatlasz 4 ponton jelzi annak keleti és északi részéről (pl. Bátorliget, Baktalórántháza; Lesku Balázs adatai, MFA online).

1070. Dictamnus albus L.: Hevesi-sík - Kerecsend: Lógó-part (2004) [8287.2]. - Cserjésedő, szálkaperjés félszáraz gyepben cca. 50 töves állomány. Az előfordulás az érintkező Kerecsendi-erdő kisugárzásának tekinthető. Az Alföldön unikális előfordulású, számos helyről kipusztult (MFA online). A Dél-Tiszántúlon 2016-ban találta meg Vidéki Róbert új állományát Kétegyházánál (Vidéki Róbert in KoRDA et al. 2017).

1083. Acer tataricum L.: Gyöngyösi-sík - Erk: Holt-Tarna (2006); Kál: Árok-alja (2003); Kápolna: Avas-oldal (2007); Nagyút: Kis-erdő (2006), Tarnóca (2002); Hevesi-ártér - Poroszló: Lúd-pást (2016); Hevesi-sík - Egerfarmos: Kákás-tó (2002); Erdőtelek: Fácános (2002), Pásztorok-fertője (2003); Füzesabony: Buda (2017), Buda-dűlő (2017), Laskó - észak (2005), Nagy-aszó (2018), Szikszói-berek (2009); Jászivány: Iványi-erdő (2004); Kerecsend: Berek-melletti-dúlő (2016), Fácános-berek (2005), Nagy-majorsági-dúlő (2018); Pély: Ludas-dűlő (2009); Poroszló: Bika-fertő (2016); Borsodi-Mezőség - Mezőszemere: Nagy-gyep (2002), Parlag (2002), Prónay-erdő (2003) [8188.3], [8286.4], [8287.1], [8287.2], [8287.3], [8288.1], [8288.4], [8289.1], [8289.3], [8386.3], [8387.1], [8387.2], [8389.1], [8389.4], [8487.3], [8488.3]. - Erdőültetvényekben, ligeterdők szegélyében (lásd erdőtelki égerláp, Fabók-ér), regenerálódó cserjés területeken, sok esetben vízfolyásokat (Eger-patak, Tarnóca, Laskó) követve fordul elő. A vizsgált tájak területén őshonosnak tekintjük, a korábbi klimax erdőtársulások (lösz- és sziki tölgyesek, keményfa ligeterdők) karakterfajaként. Az elpusztult Hevesi-erdő lombkorona-szintjében Kitaibel tömegesként jelzi (GomBocz 1945, 
MOLNÁR 2008), de előfordulását dokumentálta a tarnaörsi fácánosból is (LŐKÖS 2001). Az érintkező dombvidéki részeken (Bükk- és Mátraalja, Tarna-völgy) gyakori, a folyamatos flórautánpótlási vonalak megléte igazolt (SснмотZER 2015). Jászdózsáról - más erdőssztyepp fajok társaságában - ALMÁDI (1985) közli. A korábban publikált elterjedési térképhez (SCHMOTZER 2014) képest számos új adat került felmérésre 2017-2018-ban. A flórajárás jobbára fátlan pusztai részeiben igen sporadikus a faj (BARTHA \& MÁTYÁs 1995, MFA online). (4.A. ábra).

1097. Euonymus verrucosus Scop.: Gyöngyösi-sík - Nagyút: Kis-erdő (2006); Hevesi-sík - Erdőtelek: Fácános (2002) [8286.4], [8387.2]. - Két kis kiterjedésű erdőszármazékból került kimutatásra (igen alacsony egyedszámban). Kitaibel a 19. sz. elején még jelezte a Hevesierdőből (GomBOCZ 1945, MoLNÁR 2008). A flórajárás jobbára fátlan pusztai részeiben igen sporadikus a faj (BARTHA \& MÁTYÁs 1995, MFA online).

1217. Chamaenerion angustifolium (L.) Scop.: Hevesi-sík - Kerecsend: Fácános-berek (2005) [8288.1]. - Felhagyott, regenerálódó kavicsbánya-gödörben került elő egy kis egyedszámú állománya. A bánya melletti Kerecsendi-erdőből nem ismert állománya, de ismerve a faj (illetve a nemzetség) jó terjedő képességét honossága nem kérdőjelezhető meg (a Bükk magasabb régióinak vágásnövényzetében - a hálótérképes adathiányok ellenére - nem ritka). A Crisicum területén igen szórványos. Endes (1985) Mezőcsát mellől telepített erdei fenyvesből jelezte. Újabb publikált előfordulásai ismertek Gyula mellől (KoRDA et al. 2017), Szentesről (TAKÁcS et al. 2016) illetve Gáborjánról (KIRÁLY \& KIRÁLY 2018).

1238. Hedera helix L.: Gyöngyösi-sík - Boconád: Temető-dűlő (2017), Tó-nyilas (2003); Hevesi-ártér - Poroszló: Belterület /felvégesi temető/ (2017); Hevesi-sík - Erdőtelek: Fácános (2002), Pásztorok-fertője (2017); Heves: Radics-tagi (2017); Jászivány: Iványi-erdő (2017); Pély: Makkos-erdő (2002); Hevesi-homok-hát - Erdôtelek: Belterület /kastélypark/ (2003); Heves: Belterület /felsővárosi temeto// (2018) [8387.2], [8387.3], [8387.4], [8389.4], [8486.1], [8487.2], [8487.3], [8487.4]. - A temetőkerti, kastélyparki adatok nyilvánvalóan szubspontán előfordulást feltételeznek és ezen előfordulási adatok további belterületi adatokkal kiegészíthetők. A vizsgált terület két nagyobb kiterjedésű erdőterületén is megjelenik (Pély és Jászivány). A közeli Jászdózsáról Buschmann (2013) is jelzi. A flórajárás pusztai részein szórványos (BARTHA \& MÁTYÁs 1995, MFA online), itt feltehetőleg őshonossága is legtöbbször megkérdőjelezhető.

1250. Chaerophyllum temulum L.: Gyöngyösi-sík - Boconád: Magtár környéke (2017); Hevesi-sík - Besenyőtelek: Rátkai-erdő (2010), Zsiga-dűlő (2017); Füzesabony: Kis-erdő (2009); Tarnaszentmiklós: Ludas-dűlő (2017); Borsodi-Mezőség - Egerlövő: Lövői-erdő (2001); Mezőszemere: Prónay-erdő (2017) [8288.1], [8289.1], [8289.4], [8387.1], [8388.4], [8389.3], [8488.3]. - Telepített erdőkben, elsősorban kocsányos-tölgyesekben fordul elő, igen szórványosan a vizsgált területen. A Crisicum Tiszától északra eső peremrészeiről csak innen származnak dokumentált előfordulásai (MFA online).

1269. Seseli annuum L.: Gyöngyösi-sík - Tarnabod: Kertalja („HB”) (2018); Hevesi-sík - Dormánd: Bánom-kert (2008), Nagy-Hanyi-puszta (2008); Erdôtelek: Bencsik (2007), Falu-rét (2008), Kőkert-kispusztai-dűlő (2007), Parlag („,HB”) (2004); Kerecsend: Lógó-part (2007) [8287.2], [8288.3], [8387.1], [8388.1]. - Löszgyepekben, csatornapartokon fordul elő. Elterjedése igen sporadikus a vizsgált területen, állományának jelentős része a Nagy-Hanyi puszta környékén (Dormánd és Erdőtelek határában) koncentrálódik. A dormándi gyűjtés herbáriumi lapja a Debreceni Egyetem herbáriumában (DE) került elhelyezésre (TAKÁcs et al. 2014a). Hegylábperemi dombvidéki gyepekben még gyakori, a síkvidékre kilépve igen szórványossá válik a flórajárás területén (MFA online). (5.H. ábra).

1271. Seseli varium Trevir.: Gyöngyösi-sík - Adács: Fügedi-árok (MG) (2016); Boconád: Csárda-lapos (2018), Két-legelő-közt (2003); Kál: Csörsz-árok (2002), Molnár-rét (2012), Száraz-nyilas (2002); Kápolna: Agyagos (2007), Alsó-rét (2008), Kis-dúlő (2007), Lövész- 
gödör (2012), Ugrató-domb (2008); Kompolt: Bika-legelő (2002), Gulya-járás (2016), Kis-rét (2012); Nagyfüged: Tarnóca (2018); Nagyút: Kis-erdő (2006), Sár-rét (2006); Tarnaörs: KisHorgas, Körtélyes; Hevesi-ártér - Újlőrincfalva: Székes-hát („,HB”) $(2000,2017) ; \underline{\text { Hevesi-sík }}$ - Átány: Egri-út-dűlő (2005), Györky-gyep (2005), Hanyi-ér (2009), Külső-Szárazbű (2005), Puky-tag (2009); Dormánd: Kis-híd-dűlő (2002), Nagy-Hanyi-dűlő (2007); Erdôtelek: Csörsz-árok (2002), Falu-rét (2002), Szécsényi-tábla (2002), Hanyi-ér (2003); Füzesabony: Csörsz-árok (2002); Heves: Fácános (1999); Jászivány: Dósa-dűlő (2003), Papp-dűlő (1999), Telki-dűlő (BZ) (2018); Templom-dűlő (1999); Kápolna: Bokros-haraszt (2017), Nagy-szög (2016); Kerecsend: Lógó-part (2004), Nagy-majorsági-dűlő (2004); Kömlő: Csincsa (2002); Poroszló: Két út köze (2004); Sarud: Nagy-lapos (2002); Hevesi-homok-hát - Erdőtelek: Bagoly-lapos („HB”) (2008), Fövény-gödri-dűlő (2003), Homok-dúlő (2008), Rejner-tábla (2008); Heves: Sári-tag (2007); Tarnaörs: Bíbic-lapos (2008); Borsodi-Mezőség - Egerfarmos: Barta-állás („HB”) (2001, 2017) [8286.3], [8286.4], [8287.1], [8287.2], [8287.3], [8287.4], [8288.1 [8288.3], [8289.3], [8387.1], [8387.2], [8388.1], [8388.2], [8388.3], [8388.4], [8389.1], [8389.3], [8389.4] , [8486.1], [8486.2], [8487.2], [8487.4], [8488.1]. Löszgyepekben illetve mezsgyéken (pl. csatorna- és árokpartokon, útszegélyekben) fordul elő. Ismertté váltak előfordulásai sziki magaskórósokból (Kompolt: Bika-legelő), leirtott akácliget szegélyéből (Kápolna: Agyagos) és parlagra betelepülve (Jászivány: Papp-dűlő). A vizsgált terület jellemző, de sporadikus előfordulású sztyeppfaja (lásd elterjedési térképét SCHMOTZER 2014). ALMÁDI (1985) ponttérképet közöl a faj tarnaörsi - jászdózsai elterjedéséről, míg a Csörsz-árokról ZóLYOMI (1969) jelzi. A flórajárás területén a leggyakoribbnak a Heves-Borsodi-síkon mutatkozik, de a löszös talajú kistájakon - a Hajdúságban és a Hortobágyon (MOLNÁR 2005) - is szórványosan előfordul (kivéve a Dél-Tiszántúlt). (5.I. ábra).

1312. Peucedanum alsaticum L.: Gyöngyösi-sík - Detk: Góré-dúlő (2016), Kis-Haraszti-dúlő (2009), Kis-Tarnócai-lapos (2003); Erk: Tarna (2005); Jászárokszállás: György-ér (2014), Jász-ér (2017); Kápolna: Lövész-gödör (2012), Zsellérek-dűlője (2012); Kompolt: Bika-legelő (2002), Gulya-járás (2016), Kígyós-ér (2003), Kistérpuszta (2006), Majorsági-erdő-dűlő (2007), Majorsági-rész (2006), Rókás-garád (2003), Tarna (2012), Temető-dǔlő („HB”) (2003, 2018); Nagyfüged: Malom-tábla (2003), Tarna (2018), Tarnóca (2018); Nagyút: Búzás-féle-föld (2009), Cibik-féle-dűlő (2005), Göböl-járás (2002), Göböl-major (2013), Két-útközi-dűlő (2006), Kis-erdő (2006), Külső-tag (2006), Pásztor-szög (2005), Sár-rét (2016), Tarnóca (2005), Temetői-táblák (2002), Válykos (2002); Tarnaörs: Belső-Miske-dúlő (2017), Cenduláris (2017), Disznó-járás (2006), Horgas (2017), Körtélyes (2002), Páskom (2017), Tarna (2004), Viszneki-tó-dűlő (2014); Tarnazsadány: Bárány-járás (2008), Debrei (2018), Első-kígyós (2005), Nagy-Páskom (2005), Páli-berek (2005), Tarcsai-legelő (2018), Tarnóca (2004); Visznek: Domonkos (2006), Gyöngyös-patak (2006), Határ-fertő (2017), Holt-Tarna (2006); Hevesi-sík - Dormánd: Buda-hát („HB”) (2016), Nagy-Hanyi-dűlő (2004); Egerfarmos: Csete-föld (2017), Eger-csatorna (2017); Erdôtelek: Csörsz-árok (2002), Hanyiér (2003); Füzesabony: Buda (2002), Buda-dűlő („HB”) (2002, 2016), Csárda-tető-dúlő (2005), Laskó - dél (2005), Laskó - észak (2009), Nagy-rét (3-as fóút) (2003);; Kerecsend: Berek-melletti-dűlő (2007), Fácános-berek (2005), Lógó-part (2016), Nagy-majorsági-dűlő (2005), Sorfa-dűlő (3-as főút) (2012); Mezőtárkány: Nádi-dűlő (2017); Poroszló: Rátka (2002). [8286.4], [8287.1], [8287.2], [8287.3], [8287.4], [8288.1], [8288.2], [8288.4], [8289.3], [8385.2], [8386.1], [8386.2], [8386.3], [8387.1], [8388.1], [8389.1], [8486.1]. - Löszös gyepekben és azok degradátumaiban fordul elő. Erősen „mezsgyekövető” faj, így legtöbbször árokpartokon, útszegélyekben találkozhatunk vele. A vizsgált területen sajátos mintázatot mutat (lásd SCHMOTZER 2014 térképét): a Gyöngyösi-síkon és a Hevesi-sík északi részén gyakori, a homokvidékről és a Hevesi-ártérről teljesen hiányzik. Különösen erős állományai ismertek a nagyobb vízfolyásokat követő csatornapartokon (Laskó, Tarna, Tarnóca). A Tarna mellől Tarnaörsnél Kitaibel (LőKös 2001) és ALMÁDI (1985) is jelzi. A faj elterjedési 
térképét a vizsgált területen - a 2014-ig feltárt lelőhelyekkel - SCHMOTzER (2014) közli. Az Alföldön a vizsgált kistájak területén, a Sajó-Hernád-síkon (TAKÁcs et al. 2015) és a Crisicum délkeleti „hegylábperemén”, a Kis-Sárréten és a Bihari-síkon a leggyakoribb (MFA online).

1314. Peucedanum cervaria (L.) Lap.: Gyöngyösi-sík - Kál: Csörsz-árok (2002); Tarnaörs: Tófalu: Petes-alja-dűlő (2007); Hevesi-sík - Erdőtelek: Csörsz-árok (2002); Füzesabony: Denár-dűlő (2002); Kerecsend: Lógó-part (2004), Nagy-majorsági-dűlő (2016); Szihalom: Görbe-ér (2017), Nagy-réti-dűlő (2017) [8287.1], [8287.2], [8287.4], [8288.1], [8288.3], [8288.4], [8486.1]. - Töltésoldalakban, löszgyepekben, valamint elsődleges mezsgyéken, más reliktumjellegű sztyepp- és erdőssztyepp fajok társaságában fordul elő. A vizsgált területen igen ritka, előfordulása négy jelentősebb elterjedési gócpont köré szerveződik: (1) Laskó-patak terasza Kerecsendnél, (2) Füzesabony - Szihalom térségében az Eger-patak és mellékvizei közelében, (3) Csörsz-árok káli szakasza (innen már ZóLYOMI 1969 is jelzi) és a (4) Tarna töltése Tarnaörsnél. Utóbbi helyen sikerült Almádi László - Körtvélyesi-legelőre vonatkozó - adatát megerősíteni, viszont a Péterke-legelő feltörésével a másik dokumentált állomány kipusztultnak tekinthető (ALMÁDI 1985). A Crisicum Tiszától északra eső részéről, a mezőcsáti Csáti-erdőből TAKÁcs et al. (2015) közlik.

1392. Vinca herbacea Waldst. et Kit.: Gyöngyösi-sík - Kompolt: Belterület /temető/ (2012), Nagy-dűlő (2003); Hevesi-sík - Heves: Alsóvárosi-temető (2018), Mezôtárkány: Belterület /temető/ (2012) [8287.3], [8288.4], [8487.2]. - Ősi - részben akácosodó mezsgyékből - és temetőkertekből sikerült kimutatni. A hevesi temető ősi részében erős közel 300 töves állománya él. A mai településtől északra egykor elhelyezkedő Hevesi-erdőből már - a faj tudományos leírója - Kitaibel is jelezte (GomBocz 1945, MolnÁR 2008). ZólYOMI (1969) csörszárki adatát (8288.3) nem tudtuk megerősíteni, de itt elképzelhető a faj lappangása. A flórajárás egész területén igen ritka előfordulású, annak ellenére, hogy az érintkező hegylábperemeken jelentős állományai élnek (SRAMKó et al. 2008, SCHMOTZER 2015, MFA online).

1396. Vincetoxicum hirundinaria Medik.: Gyöngyösi-sík Kál: Árok-alja (2002), Csörsz-árok (2003); Kompolt: Kistérpuszta (2006), Majorsági-rész (2006); Tarnaörs: Tarna (2017); Hevesi-ártér - Pély: Téglaégető („HB”) (2015); Hevesi-sík - Füzesabony: Nagy-rét (3-as főút); Denár-dűlő (2017); Jászivány: Iványi-erdő (2004); Kerecsend: Fácános-berek (2005), Lógópart (2016); Sarud: Báró-árka (FA) (2016); Hevesi-homok-hát - Heves: Góbis-halom (2003) [8287.2], [8287.3], [8288.1], [8288.2], [8288.4], [8387.1], [8387.2], [8389.3], [8486.1], [8487.3], [8588.1]. - Erdőültetvényekben (kocsányos tölgyesekben, akácosokban) valamint löszdegradátumokban, mezsgyéken fordul elő, elsősorban a vizsgált terület északi felében. A puszta belső részéből, Sarudnál került elő csatornaperemen (Ferenc Attila adata). Pélynél - ahol további dombvidéki fajok (pl. Dorycnium herbaceum) társaságában fordul elő - vésztározó töltés építésnél használt andezitmurvával hurcolódhatott be. MARSCHALL \& VoJTKó (1989) füzesabonyi adata (Denár) is megerősítésre került, ahol több ponton is előfordul az Eger-patak egykori árterén. A vizsgált terület nyugati pereméről, Jászdózsáról ALMÁDi (1985) közli. A faj a Nagy-Alföld középső - jobbára kötött talajú - részéről teljesen hiányzik, a peremeken szórványos (MFA online). Tiszaladányról és Taktabájról, ártéri tölgyesekből TAKÁcS \& ZsólYomi (2010) jelzik. (4.J. ábra).

1412. Lithospermum officinale L.: Hevesi-sík - Heves: Belterület /Alsóvárosi-temető/ (2018), Dobó-tag (2002), Fácános („HB”) (1999), Hanyi-ér (2007); Hevesi-homok-hát - Erk: Nyárfás (2009); Kál: Zelei-erdeje (2017); Tarnaörs: Bíbic-lapos (2017) [8387.2], [8486.2], [8487.2], [8488.1]. - Erdős, cserjés helyek ritka faja a vizsgálati területen. Kálnál akácosban, míg Erknél homoki nemesnyárasban fordul elő. A Hevesi-erdőből (Hevesi-homokhát) egykor Kitaibel is jelezte (GomBocz 1945, MolNÁR 2008). Országosan adathiányosnak tekinthető taxon (MFA online). Az érintkező bükkaljai kistájban jelentős számú új adata került publikálására (SCHMOTZER 2015). 
1422. Echium maculatum L.: Gyöngyösi-sík - Nagyút: Sár-rét (2006); Hevesi-sík - Füzesabony: Mogyorós (2004); Kerecsend: Lógó-part (2004) [8286.4], [8287.2], [8288.1]. - A kerecsendi Lógó-parton félszáraz gyepben él (a monitorozási adatok alapján csökkenő egyedszámmal). Egyetlen töve került elő löszgyepből a Bene-patak teraszáról (Nagyút). A vizsgált tájak területéről több archív adattal is rendelkezünk. Tarnaörsnél (konkrét helymegjelölés nélkül) Tauscher Gyula gyűjtötte 1864-ben (BP; kvadrátazonosító: 8486.2), míg ZóLYOMI (1969) a Csörsz-ároknál találta [kvadrátazonosító: 8288.3]. Feltehetőleg Thaisz Lajos 1910. évi gyűjtése is a vizsgált területről származik (BP; „sub Monte Mátra, ad pagum Kál”; [8287.4]). Hegylábperemi előfordulásai unikálisak, többnyire fel is számolódtak a nagyfokú élőhelyátalakítások miatt (BARINA 2014)

1423. Pulmonaria obscura Dumort.: Borsodi-Mezőség - Mezőszemere: Prónay-erdő (2017) [8289.1]. - Kocsányos tölgy erdőtelepítésében - több kollin faj társaságában - fordul elő. A flórajárás területén igen szórványos, inkább unikális előfordulású (MFA online). A Hevesierdőből, Kitaibel által jelzett $P$. officinalis adat feltehetőleg erre a taxonra vonatkozott (GombocZ 1945, MolnÁR 2008).

1426. Pulmonaria mollissima A. Kern.: Gyöngyösi-sík - Kápolna: Avas-oldal (2007); Hevesisík - Kerecsend: Lógó-part (2016) [8287.1], [8287.2]. - Félszáraz gyepből (Kerecsend) illetve kökényes mezsgyéből (Kápolna) vált ismertté a faj a térképezés során. A Kerecsendi-erdőben erős állománya él, a lógó-parti állomány ennek déli kisugárzásának tekinthető. A vizsgált területről korábbi adata nincs. A Crisicum-ra vonatkozó irodalmi adatokat újabban LuKÁcs et al. (2017) foglalták össze.

1429. Symphytum tuberosum subsp. angustifolium (A. Kern) Nyman: Borsodi-Mezőség Mezôszemere: Prónay-erdő (2003) [8289.1]. - Telepített kocsányos tölgyesben, egyéb lomberdei fajok társaságában fordul elő. A Crisicum területén ez az egyetlen előfordulása ismert (az állomány megléte 2017-ben megerősítésre került). Az online atlaszban szereplő tiszaújvárosi adatom (ID=5790584; [8092.3]) téves, egyúttal törlendő, illetve a kvadrátban előforduló $S$. officinale-ra javítandó.

1449. Myosotis sparsiflora J.G. Mikan: Hevesi-sík - Besenyốtelek: Zsiga-dúlő (2017); Füzesabony: Kis-erdő (2009); Borsodi-Mezőség - Mezőszemere: Prónay-erdő (2017) [8288.1], [8289.1], [8388.4]. - Telepített tölgyesből és más származékerdőkből került kimutatásra. A vizsgált területen és a Nagy-Alföldön igen szórványos előfordulású (MoLNÁR 2005, MFA online).

1477. Teucrium chamaedrys L.: Gyöngyösi-sík - Kál: Csörsz-árok (2003); Hevesi-sík - Erdőtelek: Csörsz-árok (2002); Kerecsend: Lógó-part (2004), Nagy-majorsági-dűlő (2016) [8287.2], [8288.1], [8288.3], [8387.1]. - Reliktumjellegú félszáraz gyepekből és löszgyepek vált ismertté. A Hevesi-homokhátról - bár régi Kitaibel adata ismert a Hevesi-erdőből (MoLNÁR 2008) - nem került elő. A Hevesi-homokháttól keletre és nyugatra futó Csörsz-árok szakaszon is előfordul, a sáncároktól délre nem fordul elő. A Crisicum területén igen egyenlőtlen az elterjedése, a Maros-hordalékkúpon (kvadrátszinten) gyakori, ettől északra ritka előfordulású (lásd MoLnÁr (2005) adatait is). Takács Attila két temetőkertből közli a SajóHernád-síkról (TAKÁcs et al. 2013). (5.J. ábra).

1488. Phlomis tuberosa L.: Gyöngyösi-sík - Adács: Fügedi-árok (MG) (2016), Külső-Mérgespatak (MG) (2014), Boconád: Nagy-legelő (2003); Detk: Bika-dűlő (UL) (2013), Kis-Tarnócailapos (2003); Erk: Gosztonyi-föld (2001), Kárász-csatorna (2001); Jászárokszállás: Belsőszőlő; Jászdózsa: Vágó-járás (2014); Kál: Ârnyék-alja-dűlő (2002), Árok-alja (2002), Csörszárok (2003); Kápolna: Agyagos (2007), Alsó-rét (2008), Avas-oldal (2007), Bika-rét (2008), Felső-rét (2003), Kender-föld (2008), Kis-dúlő (2007), Lövész-gödör (2007), Ugrató-domb (2003); Kompolt: Belterület /temető/ (2012), Kígyós-ér (2003), Majorsági-erdő-dűlő (2003), Majorsági-rész (2006), Nagy-dúlő (2003); Ludas: Bika-part (2012), Felső-rét (2012); Nagyfüged: Belterület /temető/ (2015), Kertészeti (2004), Tarnóca (SziT) (2007!); Nagyút: 
Birka-legelő (2006), Csapás (2006), Fekete-árok (2002), Göböl-járás (2002), Kis-erdő (2006), Külső-tag (2007), Pásztor-szög (SJ) (1999), Sár-rét (2006), Tarnóca (2002), Temetői-táblák (2002), Válykos (2002); Tarnaméra: Iskola-dúlő (1999), Pusztafogacs (1999); Tarnaörs: Külső-Miske-dúlő (2014), Péterke (2017), Viszneki-tó-dúlő (2014); Tarnazsadány: Nagy-Páskom (2005), Páli-berek (2005), Tarcsai-legelő (2018), Tarna (2002), Tarnóca (2005); Visznek: Csörsz-árok (2002), Homok-dűlő (2017), Tarna (2006); Hevesi-ártér - Kisköre: Nagy-kút-dűlő (2005); Pély: Picinges-dúlő (2004); Tarnaszentmiklós: Fűzfák-alja (2002), Hanyi-ér (2002), Pap-föld (1999); Hevesi-sík - Átány: Alsó-Szárazbű (2001), Bódiúti-dúlő (2001), Egri-út-dűlő (2009), Felső-Szárazbű (2009), Györky-gyep (1999), Hanyi-ér (2001), Király-fertő (2003), Kis-kút-dúlő (1999), Raglovics-tábla (2012); Dormánd: Ér-hát (1999), Hanyi-ér (2001), Hanyi-hát (2004), Homokos-görbe (TJ) (2005), Kápolna mellettidűlő (2001), Kis-híd-dűlő (2002), Kis-híd-mező (2002), Nagy-Hanyi-dűlő (2005), Nagy-Hanyi-puszta (2003); Egerfarmos: Sély-halom (2002); Erdőtelek: Bencsik (2000), Csörsz-árok (2002), Falu-rét (2002), Kő-kerti-csatorna (2009), Szakállas (TJ) (2005), Hanyi-ér (2001); Füzesabony: Belterület /Szihalmi u./ (2003), Bozsi-dűlő (FA) (2015), Buda (2002), Csárdatető-dűlő (2003), Csörsz-árok (2002), Kis-kúti-legelő (2003), Kis-rét (2003), Laskó - dél (2002), Laskó - észak (2009), Mogyorós (PA) (2003!), Nagy-rét (3-as főút) (2003), Szikszó (2003), Szőlő-hát (2002); Heves: Bika-Nyilas (2003); Hevesvezekény: Görbe-éri-csatorna (1999), Hosszú-dúlő (SJ) (2005), Hosszú-fertő (1999), Lenke-állás (2002), Makkai-gyep (2005), Nagy-halom-dűlő (1999), Nyári-járás (2002), Vörös-kút-hát (BZ) (2018); Jászivány: Horváth-dúlő (2004), Pélyi-dúlő (2000), Telki-dűlő (2000), Templom-dúlő (1999); Kápolna: Homok-dűlő (2016); Kerecsend: Alsó-kis-erdő (PA) (2003), Fácános-berek (2005), Lógópart (2003), Nagy-majorsági-dűlő (2003); Kömlő: Bíbic-járás (1999), Gulya-gyep (TL) (2004), Kákás-fenék (2002), Kis-tanyasi-dűlő (2003), Nagy-járás (2002), Peres-alji-erdő (2002); Mezôtárkány: Belterület /temető/ (2012), Laskó (2017), Nádi-dűlő (TJ) (2005); Pély: Jászivány-dúlő (2018), Ludas-dűlő (2000); Poroszló: Benke-lapos (BZ) (2017), Csorda-legelő (2005), Farmosi útra-járó (2018), Két út köze (2005), Két-út közi-major (2018), Kis-Fehérakla (2001), Nagy-állás (2001), Nagy-Fehér akla (2005), Pupi-lapos (2001), Szőr-halom (2004); Sarud: Berec-fenék (2002), Csárda-lapos (2004), Cserepes-tábla (2006), Csincsa (2002), Fekete-rész (2006), Jánosi-legelő (2002), Kalapos-csatorna (2002), Tepélyi-rész (2001); Szihalom: Nagy-rét (2014); Tenk: Besenyő-árok (2014), Csali-dúlő (2001), Halomitábla (2001), Legelő-dűlő (2004); Újlórincfalva: Rátka (2000); Hevesi-homok-hát - Heves: Sári-tag (2007); Borsodi-Mezőség - Egerfarmos: Barta-állás (2001), Rima (2002); Mezőkövesd: Kánya-patak (2003), Mezőszemere: Belterület /Rima töltés/ (2002), Mulyoki-szántó (FA) (2014), Prónay-erdő (2003), Rima (2002) [8286.3], [8286.4], [8287.1], [8287.2], [8287.3], [8288.1], [8288.2], [8288.3], [8288.4], [8289.1], [8289.2], [8289.3], [8289.4], [8385.2], [8386.1], [8386.2], [8386.3], [8386.4], [8387.1], [8387.2], [8387.3], [8388.1], [8388.2], [8388.3], [8388.4], [8389.1], [8389.2], [8389.3], [8389.4], [8390.1], [8486.1], [8487.2], [8487.3], [8487.4], [8488.1], [8488.3], [8587.2]. - Löszgyepekben, elsődleges és másodlagos mezsgyéken, szórványosan akácligetek és egyéb záródó (pl. kökénycserjések) élőhelyeken fordul elő. Három temetőkertből is előkerült (Kompolt, Mezőtárkány, Nagyfüged). Számos állomány csak igen kis egyedszámú, így kiemelten veszélyeztetett az élőhelyátalakítások során. A vizsgált területen számos új lokalitása vált ismertté az elmúlt évtizedekben (szinte az összes kvadrátból rendelkezünk immár recens adattal). A Hevesi-ártéren csak kistájhatáron fordul elő. A Hevesi-homokháton igen szórványosan, két mezsgyéből került kimutatásra. A faj elterjedési térképét a vizsgált területen - a 2014-ig feltárt lelőhelyekkel - SCHмотZER (2014) közli. Az egykori Hevesi-erdőből származó Kitaibel adat így is megerősítésre került (GOMBOCZ 1945), mely homoki előfordulást MoLNÁR (2008) munkájában csak kérdőjelesen listáz. További - a vizsgált területről származó - archív adata ismert Kömlőről (Kitaibel ap. KANITZ 1863) és a Csörsz-árokról (ZóLYOMI 1969). A faj részletes pont- 
térképét Almádi közli a fajnak Tarnaörs, Visznek, Jászdózsa és Jászárokszállás térségéből (ALMÁDI 1984, 1985). Az 1990-es években a Hevesi-sík déli részéről, 7 pontról közölte a faj előfordulását Ambrus Béla (AmBRus 1993, 1994). A Crisicum területén a hegyláb előterekben és a löszös hátakon (lásd Hortobágy, Maros-hordalékkúp) még erős állományai élnek a fajnak (MolnÁR 2005, MFA online). (4.F. ábra).

1492. Galeopsis pubescens Besser: Hevesi-sík - Füzesabony: Buda (2017), Denár-dúlő (2017); Szihalom: Nagy-réti-dúlő (2017); Hevesi-homok-hát - Erdôtelek: Belterület /Beneskúria/ (2003); Borsodi-Mezőség - Mezőszemere: Prónay-erdő (2017) [8288.4], [8289.1], [8387.2]. - Üde élőhelyeken, vízfolyást kísérő cserjésekben (Eger-patak mentén Füzesabonynál és Szihalomnál), egykori kastélyparkban (Erdőtelek) és erdőültetvényekben (telepített tölgyes és nemesnyáras) fordul elő. A vizsgált területen igen szórványos előfordulású. A Crisicum-ban is igen ritka előfordulású, elsősorban vízfolyásokhoz (Tisza, Sajó, Hernád) kötődik (MFA online). A terület szomszédságából a jászdózsai Pap-erdőből ALMÁDI (1985) közölte.

1493. Galeopsis speciosa Mill.: Hevesi-sík - Füzesabony: Buda-dűlő (2017) [8288.4]. - Üde, tápanyaggazdag nemesnyárasból került elő kis állománya (cca. 10 tő), más dombvidéki jellegü fajok (pl. Stachys sylvatica) társaságában. Feltehetőleg - sok más fajjal egyetemben - az Eger-patak mentén terjedve jutott el ide. A flórajárás területén igen sporadikus megjelenésű, országos szinten is adathiányosnak tekinthető (MFA online).

1498. Lamium maculatum (L.) L.: Hevesi-sík - Füzesabony: Laskó - észak (2009) [8288.1]. A Laskó árvízvédelmi töltése mentén fordul elő, üde növényzetben (ártéri rét és magaskórós valamint fehér nyár liget alatt). A tárgyalt Galeopsis-fajokhoz hasonlóan viselkedik, a dombés hegyvidékeken általánosan elterjedt faj a tájhatárt átlépve igen megritkul.

1509. Stachys recta L.: Hevesi-sík - Kerecsend: Lógó-part (2004) [8287.2]. - Reliktumjellegú löszgyepben fordul elő a Laskó teraszán. Meglepő módon jelenleg a többi „reliktumőrző” helyekről (lásd Csörsz-árok) és a pusztabelsőből nem került kimutatásra. Egykor a homokvidéken (Hevesi-erdő) is előfordult, Kitaibel régi adata azonban nem került megerősítésre (GomBocz 1945, MoLNÁR 2008). A nagyobb kiterjedésű löszhátakkal rendelkező pusztai tájakban (pl. Borsodi-Mezőség - Gelej térségében, Mezőkövesd; Hortobágy) jóval gyakoribb (MoLNÁR 2005, MFA online).

1510. Stachys sylvatica L.: Hevesi-sík - Füzesabony: Buda-dúlő (2017), Laskó - észak (2009) [8288.1], [8288.4]. - Laskó patak töltésaljai üde rétjében, illetve az Eger-patak mentén telepített nemesnyárasban fordul elő igen szórványosan. A hálótérképezési adatok alapján a Jászság területéről ismert a Crisicum területéről (MFA onlne).

1524. Prunella grandiflora (L.) Scholler: Hevesi-sík - Kerecsend: Lógó-part („HB”) (2016) [8288.1]. - Félszáraz gyepben, Euphorbio-Brachypodietum társulásban jelenik meg más kollin-jellegű elterjedésű fajjal együtt a Lógó-parton. Az érintkező Kerecsendi-erdőből sem ismert (SzUjKó-LACZA 1984). Az Alföld peremén is unikálisnak tekinthető. A legközelebbi ismert (a lógó-parti állománytól cca. 4,5 kilométerre) állománya a Laskó teraszán, már a Bükkalja területén a demjéni Bodzás-oldalból ismert (SCHMOTZER 2015).

1534. Origanum vulgare L.: Gyöngyösi-sík - Detk: Tarnóca-dűlő (3-as főút) (2004); Hevesihomok-hát - Erdőtelek: Fövény-gödri-dűlő (2003) [8286.1], [8387.2]. - Homoki parlagterületről (Erdőtelek) és a 3-as főút árkából vált ismertté. Kitaibel ezt a fajt is jelezte a Hevesierdőből (Goмвосz 1945). Ez a domb- és hegyvidékeken, elsősorban a tölgyesek övéhez kapcsolódó faj a nagytáj-határt átlépve igen sporadikussá válik (MFA online).

1608. Scrophularia nodosa L.: Gyöngyösi-sík - Detk: Bene-patak (2005), Tarnóca-puszta (2003); Kál: Csörsz-árok (2003), Fabók-ér (2002); Kápolna: Alsó-rét (2008), Avas-oldal (2007), Tarna (2008); Nagyút: Tarnóca (2002); Visznek: Csörsz-árok (2004), Domonkos (2006); Hevesi-ártér - Kisköre: Kanyar (2004), Tisza-rét-dűlő (2004); Sarud: Laskó (2017); Tiszanána: Tisza-tó-töltése (2009); Újlórincfalva: Laskó (2017); Hevesi-sík - Besenyôtelek: 
Laskó (2017), Rátkai-erdő (2010); Füzesabony: Buda-dűlő (2017), Laskó - dél (2002), Laskó - észak (2009), Nagy-alsó-dűlő (2005), Ó-Laskó (2002); Kerecsend: Fácános-berek (2005); Mezôtárkány: Laskó (2002), Tárkányi-erdő (2017); Poroszló: Két út köze (2002), Laskó (2005); Borsodi-Mezőség - Egerfarmos: Rima (2002); Mezőkövesd: Kánya-patak (2017); Mezőszemere: Ostoros-patak (2003) [8285.3], [8286.4], [8287.1], [8287.2], [8288.1], [8288.4], [8289.1], [8289.2], [8289.3], [8289.4], [8386.3], [8387.1], [8388.2], [8389.1], [8389.3], [8389.4], [8588.2]. - Üde és mezofil élőhelyeken, árvízvédelmi töltéseknél, cserjésekben és telepített erdőkben fordul elő. Mintázata kettősséget mutat, részben a Bükkből lefutó patakok mentén terjed (leggyakoribb a Laskó mentén), de egy gyengébb tiszai terjedési útvonal is megfigyelhető. A Tiszai-Alföldön is sporadikus megjelenésű, mely részben adathiányra is visszavezethető (MFA online).

1614. Linaria genistifolia (L.) Mill.: Gyöngyösi-sík - Kápolna: Széltó (2008), Tarna (2008); Hevesi-homok-hát - Erdôtelek: Rejner-tábla („HB”) (2008); Heves: Bazsó-major (2007); Kál: Belterület /vasútállomás/ (2003) [8287.1], [8287.4], [8387.4]. - Homoki mezsgyékből (elsősorban vasúti árkokból), parlagokon és vasútállomásról került elő. A vizsgált területen csak a Tarna hordalékkúpját követve fordul elő. Innen archív adattal is rendelkezik, a Hevesierdő tisztásáról Kitaibel jelzi (Gomвосz 19459. A Tiszai-Alföld területén a homokvidékeken gyakoribb, az inkább kötött talajú területeken szórványos vagy hiányzik (MFA online).

1615. Linaria angustissima (Loisel.) Borbás: Hevesi-sík - Heves: Bika-Nyilas (2003), Gazdáklegelője (2004), Hanyi-ér (2002), Radics-tagi-legelő (2002), Régi-tagosok (1999); Hevesvezekény: Borjú-járás (2002), Kis-Ludas („HB”) (1999), Makkai-gyep (2005); Jászivány: Telkidűlő (2000), Vágó-járás (2004); Kerecsend: Fácános-berek (2005); Pély: Tag-dűlő (2004); Tarnaszentmiklós: Nagy-juhász-fertő (2002); Tiszanána: Galambos (2002), Magas-határdúlő (2002) [8288.1], [8487.2], [8487.3], [8487.4], [8488.1], [8488.2], [8488.3], [8587.2]. Általában degradált helyeken (pl. löszlegelőkön), útárokokban, csatornatöltéseken fordulnak elő kis egyedszámú állományai. Elterjedésének gócpontja a belső pusztarészekre, Heves - Hevesvezekény - Jászivány települések által lehatárolható területre esik. Szórványosan elsődleges mezsgyékben, így községhatárokon is előfordul. Boros Ádám is a pélyi Kis-halom dűlőben gyűjtötte, mezsgyén (Boros 1944 ap. Boros 1973). A faj országos szinten is adathiányos, elterjedésének túlsúlya a Duna vonalától keletre esik. A Crisicum területéről a Maroshordalékkúp érintett kvadrátjaiból mindből jelezték (MFA online).

1617. Linaria biebersteinii Besser: Gyöngyösi-sík - Tarnaörs: Viszneki-tó-dűlő (2014); Hevesi-sík - Kerecsend: Lógó-part („HB”) (2016), Nagy-majorsági-dűlő (2014); Poroszló: NagyFehér akla („HB”) (2005); Hevesi-homok-hát - Heves: Hevesi határra járó („HB”) (2014) [8288.1], [8389.3], [8485.2], [8486.1], [8487.1]. - Az előző fajhoz hasonló élőhelypreferenciával rendelkezik, esetenként jobb természetességú löszgyepekben is találtam, de a másodlagos élőhelyeken való előfordulás (pl. 31-es fóút árka) is jellemző. Az előző fajnál jóval ritkább. Országos elterjedésének jelentős része a Crisicum-ra esik, annak is a Tiszától keletre eső része a meghatározó (JAKAB \& TóTH 2003, JAKAB 2005, MoLNÁR 2005, MFA online).

1639. Veronica teucrium L. L.: Gyöngyösi-sík - Nagyfüged: Tarnóca (2009); Nagyút: Göböljárás (2002), Kis-erdő (2006), Külső-tag (2006), Tarnóca (2005), Temetői-táblák (2002), Válykos (2002); Tarnazsadány: Tarnóca („HB”) (2004); Visznek: Tarna (2006) [8286.4], [8287.3], [8386.2], [8386.3]. - Töltésoldalakban, mezsgyéken szórványos előfordulású. A faj csak a Gyöngyösi-sík területéről (Tarna és a Tarnóca mellől) került elő a vizsgált tájak közül. Archív adata ismert homokról (Hevesi-erdő; Kitaibel ap. GomBocz 1945, MoLNÁR 2008), mely előfordulást már nem tudtam megerősíteni. A Crisicum észak-nyugati, hegylábperemi feléből ismertek előfordulásai, tipikus Matricum-ból leereszkedő fajnak tekinthető (MFA online).

1662. Melampyrum barbatum Waldst. et Kit.: Gyöngyösi-sík - Boconád: Lapos-rét (2015), Nagy-legelő (2017); Detk: Kis-Haraszti-dúlő (2009), Tarnóca-dűlő (2004), Erk: Szőlő-aljadűlő (2001); Tarnaméra: Nagy-szék (2018); Hevesi-ártér - Pély: Hanyi-ér (2003); Hevesi-sík 
- Heves: Bika-Nyilas (2003), Gazdák-legelője (2004); Jászszentandrás: Tadra (2004); Kerecsend: Lógó-part (2016); Pély: Bodzás-hát (2004); Hevesi-homok-hát - Erk: Nyárfás (2006); Tarnaörs: Bíbic-lapos (2004); Borsodi-Mezőség - Egerlövő: Lövői-erdő (2001) [8286.4], [8287.2], [8289.4], [8386.4], [8387.1], [8387.3], [8486.2], [8487.1], [8487.2], [8487.4], [8488.3], [8588.1]. - Elsősorban zavart gyepekben, út- és csatornaoldalakban fordul elő, de ismertek előfordulásai homoki nemesnyárasokból is. Ahogy a Tiszai-Alföld területén, úgy a vizsgált területen is szórványos előfordulásúnak tekinthető (MFA online).

1726. Galium odoratum (L.) Scop.: Hevesi-sík - Besenyőtelek: Rátkai-erdő (2000); Jászivány: Iványi-erdő (BP) (2015); Mezőtárkány: Tárkányi-erdő („HB”) (2017) [8388.2], [8389.3], [8487.3]. - A három legjelentősebb kiterjedésű telepített kocsányos tölgyes erdőtömbből került elő. Állományai stabilak, a Rátkai-erdőben a polikormonok enyhe növekedése is megfigyelhető. Fagetalia elemként unikális előfordulásúnak tekinthető a vizsgált területről. A Crisicum északi hegylábperemi részéről ismert igen szórványosan (MFA online), egy újabb adata került publikálására Hortobágy térségéből, szintén telepített tölgyesből (Balmazújváros; Schmotzer in LuKács et al. 2017).

1728. Galium glaucum L.: Hevesi-sík - Erdôtelek: Csörsz-árok (2002); Kál: Csörsz-árok (2002) [8287.4]. - A vizsgált területről csak a Csörsz-árok Erdőtelek - Kál szakaszáról sikerült kimutatni, ahol szálkaperjés reliktumjellegủ gyepekben él. Ezzel ZóLYoмI (1969) régi adata is megerősítést nyert. A Crisicum területén igen sporadikus elterjedésű (MFA online). Hortobágyi előfordulásait MoLNÁr (2005) közli, míg a Hernád mellől a Németi-halomról Takács közölte a fajt, a bizonyító herbáriumi példány a Debreceni Egyetem Herbáriumában (DE) került elhelyezésre (TAKÁCS et al. 2013, TAKÁcs et al. 2014b).

1747. Cruciata pedemontana (Bell.) Ehrend.: Gyöngyösi-sík - Erk: Gulya-járás (2006); Hevesi-ártér - Poroszló: Sárádi-legelő (2015); Hevesi-sík - Kömlő: Kis-legelő (2006); Pély: Ludas-fertő (2013), Tag-dűlő (2006); Poroszló: Nagy-állás (2005), Nagy-Fehér akla (2005) [8388.3], [8389.1], [8389.4], [8486.2], [8488.3], [8587.2]. - Löszhátakon, löszlegelőkön és cickórós pusztákon fordul elő, szinte kizárólag a Csörsz-árok vonalától délre. A Hevesi-homokhátról nem ismert recens adata, Kitaibel még jelezte a Hevesi-erdőből (GomBocz 1945, MoLNÁR 2008). A vizsgált területen szórványos előfordulású, a Crisicum más kistájaiban jóval gyakoribb (pl. Hortobágy és Bihari-sík térsége; MFA online).

1797. Campanula glomerata L.: Hevesi-sík - Kerecsend: Fácános-berek (2005), Lógó-part (2016) [8287.2], [8288.1]. - Felszáraz, cserjésedő gyepben, illetve erdőszegélyben fordul elő a vizsgált terület északi határánál, tájhatáron. A Crisicum területéről csak a dél-keleti hegylábperemről ismert (Bihari-sík; MFA online).

1801. Campanula bononiensis L.: Gyöngyösi-sík - Kál: Árok-alja (2002), Csörsz-árok („HB”) (2002, 2018); Kápolna: Avas-oldal (2007), Kígyós-ér (2012), Tarna (2008); Kompolt: Kígyósér (2003), Nagy-dúlő (2003); Hevesi-sík - Erdôtelek: Csörsz-árok (2002), Szakállas (2002); Füzesabony: Csörsz-árok (2002), Mogyorós („HB”) (2018); Kerecsend: Lógó-part (2004); Hevesi-homok-hát - Kál: Seres-laposa (2008) [8188.3], [8287.2], [8287.3], [8287.4], [8288.1], [8288.3], [8387.1]. - Tipikus mezsgyelakónak tekinthető, mely alkalmanként löszgyepekben (Kápolna térsége, Lógó-part) illetve erdőtelepítések szegélyében is előfordul. Csak a vizsgált terület északi részéről ismert, déli elterjedését a Csörsz-árok kelet - nyugat futásirányú mezsgyéje jelöli ki. A flóravidék határát a Matricum felől csak igen szórványosan lépi át (MFA online).

1802. Campanula rapunculoides L.: Gyöngyösi-sík - Detk: Tarnóca (2003) [8286.4]. - Mezofil cserjésben a Tarnóca-patak mentén. Feltehetőleg a Mátrából származó állomány, mely a vízfolyás mentén juthatott le a vizsgált területre (más üde lomberdei fajok társaságában, pl. Galanthus nivalis). A Tiszai-Alföldön igen szórványos, a Sajó-Hernád-sík két erdőmaradványából (Sajóládi-erdő, Csáti-erdő) ismertek recens előfordulási adatai (ENDES 1985, TAKÁcS et al. 2013). A Hortobágy térségéből MoLNÁR (2005) ismerteti két előfordulását. 
1821. Solidago virgaurea L.: Gyöngyösi-sík - Kál: Borjú-járás (2002), Csörsz-árok (2003); Hevesi-sík - Erdőtelek: Csörsz-árok (2002), Szakállas (2002); Hevesvezekény: Kökényes (2009); Kerecsend: Lógó-part (2016); Hevesi-homok-hát - Kál: Akasztó-part (2002); Borsodi-Mezőség - Egerlövő: Hármas-határ (2017) [8287.2], [8287.3], [8287.4], [8288.1], [8288.3], [8289.4], [8387.1], [8387.2], [8488.1]. - Változatos élőhelyekhez kötődik, lösz- és degradált homoki gyepeken kívül, ismertté vált nemesnyáras erdőtelepítésből (Erdőtelek: Szakállas) és visszagyepesedő parlagterületről (Hevesvezekény) is. Utóbbi állománya a legdélebbi a vizsgált területen, a faj jobbára a hegylábperem alatti sávban fordul elő. A csörszárki előfordulást már ZóLYOMI (1969) is jelezte, ahol jelenleg is a legerősebb állományok fordulnak elő. A Crisicum területén igen szórványos: Schmotzer és Sulyok a Mezőcsáti-erdő rontott tölgyes állományrészéből jelzik (in TAKÁCS et al. 2013).

1828. Aster linosyris (L.) Bernh.: Hevesi-sík - Dormánd: Ér-hát („HB”) (2008); Füzesabony: Csárda-tető-dűlő (2005); Kerecsend: Lógó-part (1998, 2004), Rét feletti-dűlő (2016) [8287.2], [8288.1], [8388.1]. - Reliktumjellegű gyepekben (sziki magaskórósban /Dormánd/, löszös félszáraz gyepben /Kerecsend/) valamint Prunetum jellegủ mezsgyéből /Füzesabony/ vált ismertté a területről. A lógó-parti előfordulás már a bükki flóraműben is publikálásra került (Schmotzer in VoJTKó 2001). A Criscum területén elsősorban a Hortobágy és a Tápió-vidék térségében a leggyakoribb, a sziki kórósok ritka, de jellemző fajaként (SzUJKóLACZA et al. 1982, MOLNÁR 2005, MFA online).

1852. Inula conyza DC.: Gyöngyösi-sík - Boconád: Temető-dűlő (2017); Detk: Tarnóca-dűlő (3-as főút) (2004); Tarnaméra: Nagy-szék (2018); Tarnaörs: Tarna (2014); Hevesi-ártér Pély: Gazdag-puszta (2018); Hevesi-sík - Erdôtelek: Felső-teleki-puszta (2017), Pásztorokfertője (2017); Heves: Második-nyomás (2018); Jászivány: Bútelki-erdő (2017), Iványi-erdő (2004); Pély: Makkos-erdő (2002); Hevesi-homok-hát - Erk: Nyárfás (2009) [8286.4], [8287.4], [8386.4], [8387.2], [8387.3], [8486.1], [8486.2], [8487.2], [8487.3], [8487.4]. - Telepített erdőkben, nemesnyárasokban, ritkábban telepített kocsányos-tölgyesekben fordul elő, szórványosan a vizsgált területen. A Crisicum területén igen ritka előfordulású faj (MFA online), feltehetőleg itt, a hegylábperemekhez közel a leggyakoribb.

1856. Inula germanica L.: Gyöngyösi-sík - Adács: Fügedi-árok (MG) (2016); Kál: Csörsz-árok („HB”) (2003, 2018); Nagyút: Kis-erdő (2006); Tarnaörs: Külső-Miske-dűlő (2011), Péterke (2011); Hevesi-sík - Kerecsend: Lógó-part (2016), Nagy-majorsági-dűlő („HB”) (2003, 2016); Kömlő: Csincsa (2002), Nagy-járás (2003); Sarud: Csincsa (2002) [8286.3], [8286.4], [8288.1], [8386.3], [8387.1], [8389.3]. - Reliktumjellegú löszgyepekből, félszáraz gyepekből ismert a vizsgált terület északi részéről, de számos kisebb egyedszámú állománya vált ismerté mezsgyékből is (lásd SCHмотzeR 2014 elterjedési térképét). A belső pusztarészekben már kizárólagos mezsgyelakó. A Lógó-parton országosan is jelentős egyedszámú állománya él. Kömlő mellől már Kitaibel is jelezte (Kitaibel ap. KANITZ 1863, Soó \& MátHÉ 1938). A faj alföldi elterjedésének súlya a Crisicum-ra, annak is inkább a déli részére esik, bár a Hortobágy térségében is gyakoribbnak jelzik (MoLNÁR 2005). A Sajó-Hernád-síkon TAKÁCS et al. (2013) számos új lokalitással gazdagították ismereteinket a faj elterjedésével kapcsolatban. Fennmaradt, részben pusztuló alföldi állományai az erdőssztyepp növényzet rekonstrukcióját segítik.

1858. Inula ensifolia L.: Gyöngyösi-sík - Detk: Kis-Haraszti-dűlő (2009); Erk: Gosztonyi-föld (2009); Hevesi-sík - Füzesabony: Csárda-tető-dűlő („HB”) (2018); Jászszentandrás: Tadra (Bokor-tanyák) (2004). [8286.4], [8288.1], [8386.4], [8487.1]. - A vizsgált területen elsősorban mezsgyéken él (vasúti töltés, csatornapart). Erknél visszagyepesedő parlagterületen, míg Füzesabonynál telepített kocsányos-tölgyes alatt fordul elő. A Tiszai-Alföldön unikális jelentőségű, számos az atlaszban szereplő - publikálatlan - előfordulási adat kétes, megerősítésre szorul (lásd pl. a Borsodi-Mezőségből jelzett három kvadrát).

1899. Achillea nobilis subsp. neilreichii (A. Kern.) Velen.: Gyöngyösi-sík - Erk: Gosztonyi-föld 
(2006); Hevesi-homok-hát - Kál: Káposztás-lapos („HB”) (2017), M3-autópálya (2009), Proletár (2017) [8287.4], [8486.2]. - Elsősorban másodlagos élőhelyekről sikerült kimutatni a fajt. Kálnál autópálya (felüljáró) rézsűkben fordul elő (több ponton is), míg Erknél egykori nemesnyáras vágásterületébe betelepedve jegyeztük fel. A Crisicum területén szórványos, a Hortobágy északi felén jelentkezik egy jelentősebb feldúsulás (MFA online).

1914. Tanacetum corymbosum (L.) Sch. Bip.: Gyöngyösi-sík - Kál: Csörsz-árok (2008); Hevesi-sík - Erdôtelek: Csörsz-árok (2002); Kerecsend: Lógó-part (2004) [8287.2], [8287.4], [8288.1], [8288.3], [8387.1]. - A Csörsz-árok és a Lógó-part reliktumjellegü szálkaperjés gyepjeiből ismert a faj előfordulása ennek a síkvidéken igen ritka Quercetalia fajnak. A ZóLYOMI Bálint (1969) által közölt csörsz-árki előfordulás is megerősítést nyert. Csak a közvetlen hegylábperemen fordul elő, a Tápió-vidékre lefutó völgyekből (SCHMOTZER \& VIDRA 1998) és a Mezőcsáti-erdőből ismertek recens előfordulásai. Utóbbi helyen, Budai József adata is megerősítésre került (TAKÁCS et al. 2013).

1929. Artemisia pontica L.: Gyöngyösi-sík - Boconád: Nagy-legelő (2003); Detk: Kis-Tarnócai-lapos (MG) (2005); Kál: Réti-földek (2005); Kompolt: Bika-legelő (2002), Gulya-járás (2016), Kígyós-ér (2012), Kis-rét (2012), Kistérpuszta (2006), Majorsági-erdő-dűlő (2007), Majorsági-rész (2006); Nagyfüged: Tarna (2018), Tarnóca (2018); Nagyút: Cibik-féle-dủlő (2005), Gyepi-tábla (2007), Pásztor-szög (2005); Tarnaörs: Belső-Miske-dűlő („HB”) (2012), Külső-Miske-dűlő (2011), Páskom („HB”) (2017), Tarna (2017); Visznek: Csalános (2017); Hevesi-ártér - Pély: Hanyi-ér (1999), Kút-dűlő (2015), Picinges-dűlő (2000), Pusztahatrongyos (2009), Saj-csatorna (2015), Sarud-Saj-foki-fő́csatorna (2009); Poroszló: Belterület /felvégesi temető/ (2012); Tarnaszentmiklós: Nagy-állás (2004); Hevesi-sík - Besenyôtelek: Alsó-részi-ér-dűlő (2006), Kutyás-dűlő (2006), Zsemlyés-hát (2010); Egerfarmos: Kákás-tó (2002); Erdôtelek: Hanyi-ér (2008); Heves: Bika-Nyilas (1999), Dobó-tag (2002), Nagy-gyep (1999); Jászivány: Papp-dủlő („HB”) (1999, 2018), Vágó-járás (2004); Kerecsend: Laskó (2005), Lógó-part (2016), Nagy-majorsági-dúlő (2016); Kömlő: Csincsa (2002), Fényesitábla (2002), Görbe-éri-csatorna (2002), Hancsikos (2002), Kácsor-fenék (2003), Nagy-járás (2002), Peres-alji-erdő (2002), Pörös (2002), Szent-jánosi-tábla (2011); Pély: Kossuth-tag (2003), Tag-dúlő (2004); Poroszló: Farmosi-útra-járó (BZ) (2017), Két út köze (2017), KisFehér-akla (2009), Koppó-hát (2002), Pupi-lapos (BZ) (2017), Rátka (2003); Sarud: Báróárka (2002), Cigány-gyep (2006), Csincsa (2002), Delelői-legelő (2006), Jánosi-legelő (2006), Kalapos-csatorna (2009); Tiszanána: Bánom-kert (2003), Jegyző-tag (2003), Kishíd-árok-dűlő (2006); Újlőrincfalva: Rátka (2000); Borsodi-Mezőség - Egerlövő́: Kánya-patak (2017) [8286.4], [8287.3], [8287.4], [8288.1], [8289.4], [8386.3], [8387.1], [8388.1], [8388.4], [8389.1], [8389.2], [8389.3], [8486.1], [8487.3], [8487.4], [8488.1], [8488.2], [8488.3], [8489.1], [8587.2], [8588.1], [8588.2]. - Löszös gyepekben, töltésoldalakban, mezsgyékben fordul elő. A pusztai részek jellemző fajának tekinthető, mely a homokhát területéről hiányzik. A Hevesi-ártér kötött talajú területén is előfordul, bár itt legtöbbször már csak mezsgyén és töltésoldalakon (pl. Hanyi-ér töltése) jelentkezik. Kömlőrőll már Kitaibel is jelezte útszegélyből (Kitaibel ap. KANıTZ 1863, LőКÖS 2001). Tarnaörs környékéről már Kitaibel (LőKös 2001) és ALMÁDI (1985) is közölte, itt a vizsgált terület nyugati részén ma is gyakorinak tekinthető. A lógó-parti előfordulás már a bükki flóraműben publikálásra került (Schmotzer in Vојтко́ 2001). A faj hazai elterjedésének jelentős része Kelet-Magyaroroszágra esik, ezen belül a Crisicum és a Matricum hegylábperemi részei kitüntetett jelentőséggel bírnak (SCHMOTZER 2015, MFA online). (5.B. ábra).

1935. Doronicum hungaricum (Sadler) Rchb.: Gyöngyösi-sík - Kápolna: Avas-oldal (2007); Borsodi-Mezőség - Mezőszemere: Prónay-erdő (FA) (2016!) [8287.1], [8289.1]. - Kápolnánál a Tarna teraszára telepített elegyes fenyves alatt és annak kökényes szegélyéből került elő (erős közel 450 töves állomány!), míg a Prónay-erdőben telepített tölgyes nyiladékában él (közel 100 töves állomány). Régi irodalmi adata van a Hevesi-erdőből (Kitaibel ap. GoMBocz 
1945, MOLNÁR 2008), ahonnan az élőhely felszámolása miatt kipusztult. A Kerecsendi-erdőben jelenleg is jelentős állománya él (SzujKó-LACZA 1984, VojTKó 2001), de a kapcsolódó Lógó-partra nem lép ki a faj. A Tiszai-Alföld területén igen szórványos, fóleg nagyobb erdőtömbökhöz kötődik (pl. Újszentmargita; SzujKó et al. 1982). A Mezőcsáti-erdőből, Budai adata is megerősítést nyert a közelmúltban. Ezen kívül a Hejő mentéről (Igrici) közölték új előfordulását (TAKÁCS et al. 2013).

1977. Carduus hamulosus Ehrh.: Hevesi-ártér - Pély: Picinges-dűlő (2004); Hevesi-sík Jászivány: Templom-dűlő (1999); Kerecsend: Lógó-part (PA) (2016) [8287.2], [8288.1], [8487.4], [8587.2]. - Löszgyepmaradványokból, mezsgyékről ismertek állományaik, a vizsgált terület 3 pontján. Az állományok összegyedszáma igen alacsony, élőhelyük igen sérülékeny. Mint jellemző „nem ritka löszgyomnövényt” Kitaibel jelezte Kömlő térségéből is (Kitaibel ap. KANITZ 1863, LőKÖs 2001; érintett hálóegység: 8388.4). Boros Ádám szintén Kömlő és Âtány között jegyezte fel (Boros 1936 ap. BoRos 1973). Hazánkban szórványosan előforduló pusztai növény, melynek legjelentősebb állományai a Körös-Maros közén élnek (JAKAB 2012, MFA online).

2008.1. Centaurea scabiosa L. /incl. subsp. sadleriana (Janka) Asch. et Graebn./: Gyöngyösisík - Jászárokszállás: Hármashatár (Borsos-domb) (2014); Jászdózsa: Borbély-töltés (2014); Kompolt: Gulya-járás (2016), Tarna (2016); Tarnaörs: Viszneki-tó-dúlő (2014); Hevesi-ártér - Pély: Hanyi-ér (2003); Hevesi-sík - Erdôtelek: Csörsz-árok (2005); Füzesabony: Sós-rév (2017); Kápolna: Homok-dúlő (2016); Kerecsend: Berek-melletti-dűlő (2007), Lógó-part (2004); Pély: Aranyosi-csatorna (2003); Poroszló: Rátka (2003); Hevesi-homok-hát - Heves: Belterület /Vesszős u./ (2015), Sári-tag (2015); Kál: Öreg-Czibere-hegy (2003); Kápolna: Bokros-dúlő (2016); Borsodi-Mezőség - Borsodivánka: Rima (2017) [8287.2], [8288.1], [8288.2], [8288.3], [8290.3], [8387.1], [8387.2], [8389.1], [8486.1], [8487.2], [8588.1]. Löszgyepekben, mezsgyéken, csatornapartokon fordul elő, szórványosan a vizsgált területen. A „scabiosa” alakkörön belül a sadleriana / scabiosa sensu stricto alakok jóval szórványosabbak, mint a tipikus spinulosa alakok. A hegylábperemi részek átmeneti jellegét mutathatja az is, hogy ezen alakok (alfajok) számos átmeneti jellegeket mutatnak. Hasonló megállapításokat tett TAKÁCS et al. (2013) a Sajó-Hernád-sík imola-fajaival (alfajaival) kapcsolatban. Boros Ádám is Centaurea pseudospinulosa-ként azonosítt egy állományt Kompolt mellett (Boros 1944 ap. Boros 1973)

2008.2. Centaurea scabiosa L. subsp. spinulosa (Rochel) Arcang.: Gyöngyösi-sík - Adács: Mancsos (2017), Mancsos-rét (2017); Boconád: Alagút (2003), Csárda-lapos („HB”) (2017), Káposztás (2017), Messzelátó (2003); Erk: Fecske-part-dűlő (2017), Gulya-járás (2006), Járás-dúlő (2003), Kereszt-dúlő (2003), Kis-ráta (2005), Kis-Tarna (2008), Papp-halom (2003), Páskom (2017), Szőlő-alja-dűlő (2001), Tarna (2005); Kál: Árnyék-alja-dűlő (2017), Árok-alja (2002), Borjú-járás (2002), Csörsz-árok (2003), Réti-földek (2005), Száraz-nyilas (2002); Kápolna: Agyagos (2007), Alsó-rét (2008), Bika-rét (2008), Tarna (2008); Kompolt: Bacsó-éri-dűlő (2003), Belterület /temető/ (2012), Kígyós-ér (2003), Kis-rét (2012), Kistérpuszta (2006), Majorsági-erdő-dúlő (2007), Tarna (2012), Tarna-közti-dűlő („HB”) (2018); Nagyfüged: Bene-patak (2004), Tarna (2018); Nagyút: Kis-erdő (2006); Tarnabod: Kálikülső (2003); Tarnaméra: Banka-tanyák (2003), Tarna-nyilasi-dűlő (2003); Tarnaörs: Horgas (2017), Külső-Miske-dűlő (2014), Parajos-tó (2001), Páskom (2017), Tarna (2018), Viszneki-tó-dúlő (2014); Tarnazsadány: Tarnóca (2004); Hevesi-ártér: Kisköre: Sarud-Saj-fokifőcsatorna (2009); Pély: Picinges-dűlő (2004); Sarud: Makkos (2009); Tarnaszentmiklós: Sarud-Saj-foki-föcsatorna (2009); Hevesi-sík - Átány: Bódi-úti-dűlő (2004), Egri-út-dúlő (2005), Felső-Szárazbű (2009), Hanyi-ér (1999), Puky-tag (2009); Dormánd: Buda-hát (2002), Ér-hát (1999), Hanyi-ér (2008), Kis-híd-dűlő (2002), Kis-híd-mező (2002); Egerfarmos: Kákás-tó (2002), Sély-halom (2002); Erdőtelek: Bencsik (2007), Csörsz-árok (2008), Felső-teleki-puszta (2017), Kő-kerti-csatorna (2005), Tarna (2003); Füzesabony: Buda 
(2002), Buda-dűlő (2002), Csárda-tető-dúlő (2017), Csörsz-árok (2008), Laskó - dél (2002), Nagy-legelő (2005), Táborozó (2003); Heves: Alsóvárosi-temető (2018), Bika-Nyilas („HB”) (1999, 2018), Bútelek (1999), Dobó-tag (2002), Fácános (1999), Fácános-tanya (2007), Gazdák-legelője (2002), Hanyi-ér (1999), Nagy-gyep (1999); Hevesvezekény: Borjú-járás (2002); Jászivány: Papp-dúlő (1999), Templom-dűlő (1999), Vágó-járás (2004); Kerecsend: Laskó (2005); Mezôtárkány: Belterület /temető; vasútállomás / (2002), Laskó (2002); Poroszló: Két út köz (2002), Két út köze (2002), Kis-Fehér-akla (2002), Rátka (2002); Sarud: Csincsa (2002); Tenk: Besenyő-árok (2014), Tenki-legelő (2004); Tiszanána: Orosz-lapos (2006); Hevesi-homok-hát - Erdôtelek: Homok-dűlő (2008); Heves: Belterület /Vesszős u./ (2007), Gergely-telep (2002), Hevesi határra járó (2014), Sári-tag (2007), Szabó-tag (2002); Kál: Akasztó-part (2002), Csemetekert (2002), Első-nyomás (2002), Ugaros (2002); Tenk: Belterület /Jókai M. u./ (2005); Borsodi-Mezőség - Egerfarmos: Barta-állás (2001); Egerlövő: Eger-csatorna (2017) [8286.4], [8287.1], [8287.3], [8287.4], [8288.1], [8288.2], [8288.3], [8288.4], [8289.3], [8289.4], [8385.2], [8386.2], [8386.3], [8386.4], [8387.1], [8387.2], [8387.3], [8387.4], [8388.1], [8388.3], [8389.1], [8389.3], [8389.4], [8486.1], [8486.2], [8487.1], [8487.2], [8487.3], [8487.4], [8488.1], [8488.2], [8488.4], [8587.2]. - Löszös gyepekben, csatornapartokon és mezsgyékben fordul elő. Több temetókertből is sikerült kimutatni. A vizsgált területen gyakorinak tekinthető, számos lokalitás került felmérésre az elmúlt évtizedben. Leggyakoribb a Tarna-hordalékkúp nyugati oldalán, de szórványosan minden kistájból ismertté vált. Legritkábbnak a Hevesi-ártér területén mutatkozott. A Crisicum területén nem ritka előfordulású (MFA online). Az alakkör térképét egyben adtuk meg (5.C. ábra).

2016. Hypochoeris maculata L.: Hevesi-sík - Jászivány: Templom-dűlő (2003); Kerecsend: Lógó-part (2004) [8287.2], [8288.1], [8487.4]. - A Lógó-parton félszáraz, EuphorbioBrachypodietum gyepekben fordul elő (erős állomány), míg Jásziványnál visszagyepesedő parlagterületen találtam 1 tövét 2003-ban. Kitaibel még jelezte a Hevesi-erdőből, homokról, de itt már nem tudtam megerősíteni az előfordulását (MoLNÁR 2008). A Crisicum területéről csak innen ismert a faj (MFA online).

2041. Lactuca quercina L.: Gyöngyösi-sík - Boconád: Kavicsbányák (2018); Detk: Kis-Haraszti-dűlő (2009); Kál: Csörsz-árok* (2018); Kompolt: Majorsági-rész* (2016); Hevesi-ártér - Tiszanána: Vése (2017); Hevesi-sík - Erdőtelek: Csörsz-árki-dűlő (2017), Csörsz-árok (2017); Füzesabony: Csárda-tető-dűlő (2017), Mogyorós* (2018); Kerecsend: Laskó* (2005), Lógó-part (2016); Kömlő: Bogárzói-tábla (2018); Szihalom: Nagy-réti-dűlő* (2017); Hevesihomok-hát - Heves: Káli-dűlő („HB”) (2005), Kis-Herceg-tag* (2005); Kál: Második-nyomás (2006), Proletár (2017), Seres-laposa (2008), Zelei-erdeje (2017); Borsodi-Mezőség - Egerlövő: Lövői-erdő (2017); Mezőszemere: Prónay-erdő (2017) [8286.4], [8287.4], [8288.1], [8288.3], [8288.4], [8289.1], [8289.4], [8387.1], [8387.2], [8387.4], [8388.4], [8489.4]. Degradált erdőkben és cserjésekben, kocsányos tölgyes erdőtelepítésekben, akácosokban, ritkán csalán mezsgyékben fordul elő. Az állományok nem egységesek, a csillaggal $\left(^{*}\right)$ jelölt lokalitásokban az éplevelű var. integrifolia (= L. chaixii Vill.; L. sagittata Waldst. \& Kit.) fordul elő (szórványosan „kevert” állományok is ismertek). Kitaibel - L. stricta néven - a Hevesierdőből jelezte (Gomвоcz 1945), ebben a térségben ma is több helyen előfordul. A Crisicum területén szórványos előfordulású (MFA online). (3.I. ábra).

2046. Mycelis muralis (L.) Dumort.: Gyöngyösi-sík - Visznek: Homok-dúlő (2017); Hevesi-sík - Besenyőtelek: Rátkai-erdő (2000); Füzesabony: Kis-erdő (2017); Jászivány: Iványi-erdő (2004); Kömlő: Kis-tanyasi-dűlő (2002); Mezőtárkány: Tárkányi-erdő (2004); Pély: Makkoserdő (2002); Hevesi-homok-hát - Heves: Forrás-dűlő (2002); Tarnaörs: Bíbic-lapos (2008), Bíbic-part (2017); Borsodi-Mezőség - Egerfarmos: Barta-állás (2017), Farmosi-útra-járódűlő (2001); Egerlövő: Lövői-erdő (2001); Mezőszemere: Prónay-erdő (2017) [8288.1], [8289.1], [8289.3], [8289.4], [8386.3], [8387.4], [8388.2], [8389.3], [8486.2], [8487.3], [8487.4], [8488.1]. - Telepített, zárt erdőtömbökben, elsősorban telepített kocsányos tölgye- 
sekben fordul elő. Tipikus „erdőlakó”, így elterjedési térképe a nagyobb erdőtömbök elterjedését fedi le a vizsgált területen (lásd Schmotzer 2014 térképét). A Hortobágy térségéből viszont nyíltabb élőhelyekről, árokpartokról, mezsgyékről jelezték (MoLnÁR 2005). A Crisicum területén szórványos, a flórajárás északi részén gyakoribb (MFA online). (3.J. ábra).

2053. Lapsana communis L.: Gyöngyösi-sík - Detk: Tarnóca (2003); Kápolna: Alsó-rét (2008), Tarna (2008); Kompolt: Tarna (2003); Nagyút: Búzás-féle-föld (2016); Hevesi-sík Besenyőtelek: Rátkai-erdő (2006); Borsodivánka: Marha-járás (2017); Erdőtelek: Csörsz-árok (2008); Füzesabony: Belterület /Laskó/ (2002), Laskó - dél (2002), Laskó - észak (2009); Heves: Dobó-tag (2002); Kerecsend: Nagy-majorsági-dűlő (2005); Hevesi-homok-hát - Erdőtelek: Belterület /egykori Benes-kúria kastélyparkja/ (2003); Borsodi-Mezőség - Egerfarmos: Barta-állás (2017); Egerlövő: Lövői-erdő (2017); Mezőkövesd: Kánya-patak (2017); Mezőszemere: Parlag (2002), Prónay-erdő (2017) [8188.3], [8286.4], [8287.1], [8287.2], [8287.3], [8287.4], [8288.1], [8288.3], [8288.4], [8289.2], [8289.3], [8289.4], [8387.2], [8389.3], [8488.1]. - Félárnyékos élőhelyeken, erdőszármazékokban, azok vágásterületén, cserjésekben és vízfolyások töltését kísérve fordul elő. A vizsgált terület északi részén fordul elő hangsúlyosan, dél felé a nagyobb vízfolyások (pl. Laskó és Tarna) mentén dél felé hatol. A Crisicum területén a fátlan belső részekről szinte teljesen hiányzik (MoLNÁR 2005), a hegylábperemek közelében és vízfolyások mentén gyakoribbak. Az érintkező dombvidéki, hegylábi területeken már közönséges (MFA online).

2081. Hieracium umbellatum L.: Gyöngyösi-sík - Boconád: Csárda-lapos (2018); Detk: KisHaraszti-dűlő (2009); Erk: Gosztonyi-föld (2006); Kál: Csörsz-árok (2003); Nagyút: Kis-erdő (2006); Tarnaörs: Belső-Miske-dűlő (2017); Hevesi-ártér - Poroszló: Belterület /felvégesi temető/ (2012); Hevesi-sík - Erdőtelek: Csörsz-árok (2002), Szakállas (2002); Füzesabony: Buda-dűlő (2017), Csárda-tető-dűlő (2017), Denár-dűlő (2003), Mogyorós (2016); Jászivány: Iványi-erdő (2004); Kerecsend: Lógó-part (2004); Mezőtárkány: Nádi-dűlő (2017); Pély: Makkos-erdő („HB”) (2010); Hevesi-homok-hát-Heves: Bazsó-major (2007), Kapitányhegy (2003); Kál: Proletár (2002); Kápolna: Páskom (2015); Tenk: Forráskerti-legelő (2005); Borsodi-Mezőség - Egerlövő: Lövői-erdő (2017) [8286.4], [8287.2], [8287.4], [8288.1], [8288.3], [8288.4], [8289.4], [8387.1], [8387.2], [8387.3], [8389.2], [8486.1], [8486.2], [8487.3], [8487.4]. - Változatos élőhelyeken fordul elő, mind nyílt (löszös és homoki zavart gyepek, vasúti részűk), mind pedig zárt élőhelyeket (telepített tölgyesek) be tud népesíteni. Poroszlónál temetőkertben is előfordul. A vizsgált területen igen sporadikus, elterjedésének súlypontja az északi és a nyugati részeken van. A Crisicum területén a leggyakoribbnak is az Északi-középhegység síksági előterében található (MFA online).

2155. Ornithogalum brevistylum Wolfner: Gyöngyösi-sík - Adács: Demény-rétje (MG) (2014), Egri-part (MG) (2017), Fügedi-árok (MG) (2016), Nagy-legelő (MG) (2017); Detk: Kis-Haraszti-dűlő (2009), Kis-Tarnócai-lapos (2003); Erk: Gosztonyi-föld (2006), HoltTarna (2017), Kárász-csatorna (2001), Kis-Tarna (2017); Jászdózsa: Gyep-horgas (2008); Kál: Árnyék-alja-dűlő (2003), Csörsz-árok (2018); Kápolna: Alsó-rét (2008), Avas-alja (2007), Avas-oldal (2007), Felső-rét (2003), Kígyós-ér (2012), Zsellérek-dűlője (2003); Karácsond: Kis-Üsztökő (MG) (2016); Kompolt: Bacsó-éri-dűlő (2003), Belterület /temető/ (2012), Bika-legelő (2002), Gulya-járás (2016), Kígyós-ér (2003), Kiosztott-földek (2003), Kis-rét (2012), Kistérpuszta (2006), Majorsági-erdő-dűlő (2007), Majorsági-rész (2007), Nagy-dűlő (2003), Rókás-garád (2003), Száraz-völgy (2003), Szőr-hátra járó-dűlő (2003), Temető-dűlő (2003); Ludas: Belterület /temető/ (MG) (2015), Hármashatár-dűlő (MG) (2012); Nagyfüged: Kertészeti (2004), Kis-Füged-dűlő (2004), Majzik (2004), Malom-tábla (2003); Nagyút: Búzás-féle-föld (2009), Göböl-járás (2002), Kis-erdő (2006), Sár-rét (2007), Temetői-táblák (2002), Válykos (2002); Tarnaörs: Békás-tó (2008), Cenduláris (2008), Gulya-kút (2008), Horgas (2017), Kis-Tarna (2008), Külső-Miske-dűlő (2012), Páskom (2017), Rajna-dűlő (2008), Tarna (2017), Viszneki-tó-dűlő (2014); Tófalu: Csinált-útra-járó (MG) 
(2016), Fekete-dúlő (MG) (2016), Templom-föld (MG) (2016); Visznek: Borjúlegelő (2004), Domonkos (2006), Gyöngyös-patak (2006), Holt-Tarna (2006), Homok-dűlő (2017), Varcólapos (2017); Hevesi-ártér - Kisköre: Rákhát-dűlő (2002); Pély: Gazdag-puszta (1999), Hanyi-ér (2003), Kis-Garabont (2014), Nagy-Hatrongyos (2014); Sarud: Hosszú-hát (TL) (2005); Tarnaszentmiklós: Bogárzó-hát (2005), Göbölykút (2005), Hanyi-ér (2002), Lovasgyep (2007), Nagy Laci-fertő (2002); Tiszanána: Sarud-Saj-foki-főcsatorna (2006), Vése (TL) (2005); Hevesi-sík - Átány: Bódi-úti-dűlő (2006), Györky-gyep (2001), Hanyi-ér (1999), Kálosi-tag (2001), Kázsmán-tető (2014), Körei és posta út köze (TL) (2005), Magas-határ-dűlő (2003), Nagy-fertő (2002), Szárazbű (2006), Szikes-gyep-dűlő (2014), Szórádi-hasítás (2014), Telekalja (TL) (2005), Tető-halmi-dűlő (2002), Viski-fertő (1999); Dormánd: Kishíd-mező (2011); Egerfarmos: Eger-csatorna (2017); Erdôtelek: Falu-rét (2003); Füzesabony: Csárda-tető-dűlő (2005), Kis-kúti-legelő (2009), Laskó - dél (2014), Szőlő-hát (2002); Heves: Bika-Nyilas (1999), Harmadik-nyomás (2015), Nagy-lineáris (2014); Hevesvezekény: Görbe-éri-csatorna (1999), Hanyi-ér (SJ) (2005), Hosszú-dűlő (1999), Nagy-laposdűlő (2008); Jászivány: Iványi-erdő (2004), Papp-dűlő (2003), Vágó-járás (2004); Kerecsend: Lógó-part (2003), Nagy-majorsági-dúlő (2004); Kömlő: Bogárzói-tábla (2006), Nagy-járás (2002); Mezőtárkány: Nádi-dűlő (2017), Nagy-fenék (2018), Salamon-fertő (2015); Pély: Árendás (2005), Jásziványi-dűlő (2003), Kelemen-dűlő (1999), Kelemen-fertő (2009), Ludasi-legelő (2015); Poroszló: Két út köze (2003), Koppó-hát (2017), Laskó (2005); Szihalom: Nagy-réti-dűlő (2017); Tenk: Legelő-dűlő (2006); Tiszanána: Galambos (1999), Szabó-szállás (TL) (2005); Hevesi-homok-hát - Erdôtelek: Fövény-gödri-dűlő (2003); Erk: Nyárfás (2009); Heves: Szántai-járás (2003), Szerelem-tag (1999); Borsodi-Mezőség - Egerfarmos: Barta-állás (2017), Farmosi-útra-járó-dűlő (2001); Mezőszemere: Baglyas (2002), Ostorospatak (2002), Parlag (2002), Prónay-erdő (2017), Tökföld (2002); Szihalom: Nagy-réti-dúlő (2017) [8286.3], [8286.4], [8287.1], [8287.2], [8287.3], [8288.1], [8288.3], [8288.4], [8289.1], [8289.3], [8289.4], [8386.1], [8386.2], [8386.3], [8386.4], [8387.1], [8387.2], [8387.4], [8388.2], [8388.3], [8388.4], [8389.1], [8389.2], [8486.1], [8486.2], [8487.2], [8487.3], [8487.4], [8488.1], [8488.2], [8488.3], [8488.4], [8489.2], [8489.3], [8489.4], [8588.1] - Löszgyepekben, pusztai cserjésekben, mezsgyékben, szórványosan telepített erdők szegélyében fordul elő. A homok talajú kistájrészek kivételével nem ritka előfordulású a vizsgált területen. Kitaibel naplója alapján már két évszázaddal ezelőtt is a mezsgyék vezérnövényének számított (Kitaibel ap. KANITZ 1863, Soó \& MÁTHÉ 1938). VAJDA - dűlőnév megjelölés nélküli kerecsendi adata - feltehetőleg a vizsgált területről származik adata (Vajda in Soó \& MÁTHÉ 1938). A faj a Kerecsendi-erdő környékén löszös gyepekben, mezsgyéken ma sem ritka. A faj fő elterjedése hazánkban a Crisicum és a Matricum hegylábperemi részére esik. (5.F. ábra).

2169. Muscari neglectum Guss. ex Ten.: Gyöngyösi-sík - Jászdózsa: Gyep-horgas (2008); Kápolna: Belterület /kápolnai csata emlékparkja/ (2015); Kompolt: Belterület /temető/ (2012); Nagyút: Göböl-major (2012), Sár-rét (2007); Tarnaörs: Rajna-dűlő (2008); Tarnazsadány: Debrei (2018), Tarcsa-puszta (2018), Tarna (2002); Hevesi-sík - Átány: Bódi-útidűlő (2004), Kázsmán-lapos (2004); Egerfarmos: Belterület /temető/ (2012); Füzesabony: Nagy-alsó-dűlő (2002); Heves: Belterület /Alsóvárosi-temető/ (2018); Hevesi-homok-hát Tarnaörs: Bíbic-lapos (2008), Bíbic-part (2008), Dorkó-lapos (2008); Borsodi-Mezőség Mezőszemere: Nagy-gyep (2002), Parlag (2002), Tökföld (2002) [8286.4], [8287.3], [8288.4], [8289.1], [8289.3], [8386.2], [8387.1], [8388.3], [8486.1], [8486.2], [8487.2]. - Ősi és másodlagos gyepekben, útárkokban, mezsgyéken, ritkán telepített erdőkben. A vizsgált területen szórványos előfordulású, leginkább adathiányosként értékelendő. Ugyanez mondható el a faj Criscum-beli előfordulásáról is (MFA online).

2188. Allium oleraceum L.: Hevesi-homok-hát - Heves: Kis-Herceg-tag (2005), Ötödrész (2003) [8387.3], [8387.4]. - Homokos mezsgyén, akácos szegélyében fordul elő a Hevesi- 
homokháton. A Nagy-Alföld területén igen szórványos előfordulású (MFA online).

2192. Convallaria majalis L.: Gyöngyösi-sík - Boconád: Magtár környéke (2003); Erk: HoltTarna (2017); Hevesi-homok-hát - Erdôtelek: Belterület /Benes-kúria/ (2003); Borsodi-Mezőség - Mezőszemere: Prónay-erdő (2017) [8289.1], [8386.3], [8387.1], [8387.2]. - Egykori kastélyparkokban, idős kocsányos tölgyesek alatt fordul elő Erdőtelken és Boconádnál. Mezőszemerénél egyéb üde lomberdei faj társaságában él telepített tölgyesben, míg a HoltTarna mellett tatárjuharos erdőssztyepp erdőmaradvány szegélyében fordul elő. Ezeken kívül a településeken (pl. temetőkben) ültetett állományaik fordulnak elő (ezek listázását nem adtam meg). A Hevesi-erdőből még Kitaibel is jelezte a faj előfordulását (GomBocz 1945, MoLNÁR 2008). A Crisicum területén szórványos, elsősorban a meglévő keményfás ligeterdők előfordulásához kötődik (lásd Körösök vidéke, Taktaköz (TAKÁcs \& ZsóLYomi 2010), MFA online).

2195. Polygonatum latifolium (Jacq.) Desf.: Gyöngyösi-sík - Erk: Holt-Tarna (2017); Kál: Csörsz-árok (2002); Kápolna: Belterület /temető/ (2012); Zaránk: Belterület /temető/ (2015); Hevesi-sík - Dormánd: Belterület /temető/ (2012); Erdőtelek: Csörsz-árok (2002); Füzesabony: Buda (2017), Buda-dűlő (2017), Kis-erdő (2017), Laskó - észak (2009); Hevesihomok-hát - Heves: Herceg-erdő (2018), Kapitány-hegy (2003); Kál: Homoki-földek (2002); Borsodi-Mezőség - Mezőszemere: Prónay-erdő (2017) [8287.1], [8287.4], [8288.1], [8288.3], [8288.4], [8289.1], [8386.3], [8386.4], [8387.3], [8387.4]. - Változatos élőhelyeken fordul elő: Erknél erdőssztyepp maradványerdőben él a Holt-Tarnát kísérve, de gyakrabban erdőültetvényekben (elsősorban homoktalajon, de a Prónay-erdőben kötött talajon) is megjelenik. Négy temetőkertből is előkerült, ahová feltehetőleg a környező területekről ültették be. A csörsz-árki reliktumjellegű élőhelyről már ZóLYOMI (1969) is beszámolt. A Füzesabonytól délre eső részekre feltehetőleg az Eger-patak közvetítésével jutott. A felmért állományok jelentős része a Csörsz-árok vonalától északra található. A Crisicum területén nagy egyenetlenségeket mutat az elterjedése (MFA online), leggyakoribb a határos Matricum délnyugati előterében (elsősorban a Jászság területén) és a Körösök mentén.

2241. Galanthus nivalis L.: Gyöngyösi-sík - Detk: Tarnóca (MG) (2013) [8286.4]. - Mezofil cserjésben a Tarnóca-patak mentén, Campanula rapunculoides és a Corydalis solida társaságában. A Nagy-Alföldön unikális előfordulású faj, a flóraatlaszban jelzett további előfordulások honossága csak a primer adatok ismeretében adható meg. Soó \& MÁTHÉ (1938) csak Marosvidék határon túli részéből jelezték (Arad).

2252. Iris graminea L.: Hevesi-sík - Kerecsend: Lógó-part (2016) [8288.1]. - Félszáraz gyepben, szórványosan. Az érintkező Berek-erdőben - elsősorban a nyiladékok mentén - erős állománya él a fajnak. A Crisicum területén csak Kerecsendről és a hencidai Csere-erdőből ismert (PAPP \& DUDÁS 1989, MFA online).

2260. Iris variegata L.: Hevesi-sík - Erdôtelek: Csörsz-árok (2002); Kerecsend: Lógó-part (2004); Hevesi-homok-hát - Kál: Seres-laposa (Csörsz-árok) (2002) [8286.4], [8287.2], [8287.4], [8288.1]. - Reliktumjellegú szálkaperjés félszáraz gyepben, töviskés cserjés alatt. Az előző fajhoz hasonlóan, erős állománya él az érintkező Berek-erdőből. A Nagy-Alföldön különösen a Crisicum területén - unikális előfordulású.

2289. Luzula campestris (L.) DC.: Gyöngyösi-sík - Kápolna: Lövész-gödör (2007), Nagyút: Sár-rét (2006); Hevesi-sík - Erdôtelek: Parlag (2006); Hevesi-homok-hát - Kál: Akasztó-part (2002) [8188.3], [8286.4], [8287.4], [8388.1]. - Löszös és homoki gyepekben, igen szórványosan. A faj csak a vizsgált terület északi részéről került kimutatásra. Horváth András (2010) az Euphorbio pannonicae-Brachypodietum állományok kerecsendi (Lógó-part) felvételében jelezte a faj előfordulását. A Tiszai-Alföld területén - különösen a belső részeken igen szórványos megjelenésű (MFA online).

2333. Poa nemoralis L.: Gyöngyösi-sík - Nagyút: Kis-erdő (2006); Tarnaörs: Belső-Miskedúlő (2017); Visznek: Domonkos (2017); Hevesi-sík - Besenyőtelek: Peresi-dűlő („HB”) 
(2017); Füzesabony: Csárda-tető-dűlő (2017), Görbe-fertő (2017); Kömlő: Bogárzó-hát (2018); Hevesi-homokhát - Heves: Herceg-erdő (2018), Jászszentandrás: Erdő-alja (2017); Borsodi-Mezőség - Egerlövő: Lövői-erdő (2017); Mezőszemere: Prónay-erdő (2017) [8286.4], [8288.1], [8289.1], [8289.3], [8386.3], [8387.4], [8388.4], [8486.1]. - Telepített tölgyesekből sikerült kimutatni a faj jelenlétét a 2017-2018. évi - kultúrerdőket érintő - növénytársulástani felmérések során. A közölt adatok jelentős része új hálóegységi adatot is jelent. Kitaibel jelezte a Hevesi-erdőből (Gomвocz 1945). A Crisicum területén a faj szórványos előfordulású, részben adathiányosként is értékelhető.

2357. Melica altissima L.: Gyöngyösi-sík - Detk: Kis-Haraszti-dűlő (2009), Tarnóca (2003); Kápolna: Tarna (2008); Kompolt: Tarna (2012); Nagyút: Búzás-féle-föld („HB”) (2016); Tarnaméra: Tó-fenék (2003); Hevesi-sík - Besenyôtelek: Laskó (2017), Laskó-föld (2017); Borsodivánka: Hodály-dúlő (2017); Erdőtelek: Bencsik (2007); Füzesabony: Árva (2017), Belterület /Szihalmi u./ („HB”) (2014), Csárda-tető-dűlő (2005), Kis-erdő (2009), Laskó - dél („HB”) (2014), Laskó - észak (2009), Szikszói-berek („HB”) (2009), Szikszói-telep (2009); Kerecsend: Fácános-berek („HB”) (2005, 2018), Laskó (2004), Lógó-part (2016), Nagy-majorsági-dűlő („HB”) $(2003,2016) ;$ Hevesi-homok-hát - Heves: Kis-Herceg-tag (2003); Kál: Hatos-váltó (2008), Homoki-földek (2008); Borsodi-Mezőség - Egerlövő: Lövői-erdő (2017) [8286.4], [8287.1], [8287.2], [8287.3], [8287.4], [8288.1], [8288.2], [8288.4], [8289.1], [8289.4], [8386.4], [8387.3], [8388.1], [8389.1], [8389.2]. - Mezsgyékben, útárkokban, telepített erdőkben, illetve azok szegélyében fordul elő. Jó kolonizációs képessége és erős gyökérzete révén a kisebb zavarásokra is jól reagál. Állományai zömmel a vizsgált terület északi részéből származnak, a Csörsz-árok vonalától délre jóval szórványosabb. A tarnaörsi, egykori Orczy uradalom fácánosából Kitaibel közölte (LőKös 2001). Jászdózsáról (Papp-erdő) már JANKA (1866) illetve később ALMÁDI (1985) is jelezte a faj előfordulását. Az Alföldön az elterjedésének a jelentős része a Körös-vidékre esik, másutt jóval szórványosabb (MFA online). Az érintkező dombvidéki részeken már gyakori előfordulású (lásd SCHмотzER 2015). (4.E. ábra).

2389. Brachypodium sylvaticum (Huds.) P. Beauv.: Gyöngyösi-sík - Boconád: Csárda-lapos (2018), Magtár környéke (2003); Kompolt: Tarna (2012); Hevesi-ártér - Tarnaszentmiklós: Bólya-erdő (2002); Tiszanána: Vése (2017); Hevesi-sík - Besenyőtelek: Rátkai-erdő (2006); Borsodivánka: Marha-járás (2017); Egerfarmos: Csete-árok (2017); Füzesabony: Buda-dúlő (2017), Csárda-tető-dúlő („HB”) (2018), Denár-dűlő (2017), Kis-erdő (2009), Laskó - észak (2009); Jászivány: Bútelki-erdő (2017), Iványi-erdő (2017); Mezôtárkány: Nádi-dűlő (2017), Tárkányi-erdő (2009); Pély: Makkos-erdő (1999); Poroszló: Rátka (2002); Sarud: Kos-legelő (2002); Szihalom: Görbe-ér (2017), Nagy-réti-dűlő (2017), Varjas-erdő (2002); Hevesi-homok-hát - Heves: Herceg-erdő (2007); Tarnaörs: Kút-lapos (2004); Borsodi-Mezőség - Egerlövô: Eger-csatorna (2017), Lövői-erdő (2017); Mezôszemere: Prónay-erdő (2003) [8287.3], [8288.1], [8288.2], [8288.4], [8289.1], [8289.3], [8289.4], [8387.1], [8387.3], [8387.4], [8388.2], [8389.1], [8389.3], [8486.2], [8487.3], [8487.4], [8489.4]. - Telepített erdókben, legtöbbször kocsányos tölgyesekben, de szórványosan akácosokban, erdei fenyvesekben és amerikai kőrises származékerdőkben is előfordul. A telepített erdők növénytársulástani felmérése (2017-2018) során számos új lokalitásból vált ismertté. Szórványos mind a vizsgált terület, mind pedig a teljes Crisicum területén (MFA online). (3.B. ábra).

2390. Brachypodium pinnatum (Host) Roem. et Schult.: Gyöngyösi-sík - Kál: Csörsz-árok (2002); Kompolt: Kígyós-ér (2012); Hevesi-sík - Erdőtelek: Csörsz-árok (2002), Szakállas (2002); Füzesabony: Buda (2017), Buda-dűlő (2017), Csörsz-árok (2002), Denár-dűlő („HB”) (2002, 2017), Szőlő-hát (2002); Kerecsend: Lógó-part (2004); Mezőtárkány: Nádi-dűlő (2017); Szihalom: Nagy-réti-dűlő (2017); Hevesi-homok-hát - Kál: Seres-laposa (2008) [8287.2], [8287.3], [8287.4], [8288.1], [8288.3], [8288.4]. - Reliktumjellegü löszgyepekben, cserjésedő mezsgyéken. Legjelentősebb állományaik a Csörsz-árok különböző szakaszain ta- 
lálhatók, ettől délebre nem hatol. A flóraatlaszban a 8389.3 kvadrátban publikált B. pinnatum adatom (Besenyőtelek: Rátkai-erdő), az előző fajra, a B. sylvaticum-ra vonatkozik. A DunaTisza köze kivételével a Nagy-Alföldön igen szórványos elterjedésű erdőssztyepp fajnak tekinthető (MFA online).

2393. Elymus caninus (L.) L.: Hevesi-sík - Füzesabony: Görbe-fertő (2017), Kis-erdő (2009); Borsodi-Mezőség - Egerfarmos: Barta-állás (2017); Mezőszemere: Prónay-erdő („HB”) (2017) [8288.1], [8289.1], [8289.3]. - Telepített kocsányos tölgyesekből, magyar kőrises erdőfoltokból sikerült kimutatni az elmúlt években a vizsgált terület északi részéből. Állománya a Kerecsendi-erdőből volt ismert (ZóLYOMI 1957, SZUJKÓ-LACZA 1984), ahol most is jelentősebb állománya él a fajnak. ALMÁDi (1985) jelezte a jászdózsai Pap-erdőből is. A Körös-vidék kivételével igen szórványosan mutatkozik a Crisicum területén (MFA online). (3.H. ábra).

2396. Elymus hispidus (Opiz) Melderis: Hevesi-sík - Erdôtelek: Csörsz-árok (2008); Füzesabony: Csörsz-árok (2002); Kerecsend: Lógó-part (2004); Hevesi-homok-hát - Kál: Proletár (2002) [8287.2], [8287.4], [8288.3], [8288.4]. - Löszgyepekben, reliktumőrző mezsgyékben (pl. Csörsz-árok). A vizsgált területen igen ritka előfordulású, a Crisicum-ban is csak szórványos (MFA online).

2397. Agropyron cristatum (L.) Gaertn.: Gyöngyösi-sík - Kál: Árnyék-alja-dűlő (2002), Csörsz-árok (2003); Nagyfüged: Bene-patak (2004); Tarnaörs: Tarna (2004); Visznek: Gyöngyös-patak (2017); Hevesi-ártér - Pély: Picinges (2004); Hevesi-sík - Átány: Csohános (2003); Egerfarmos: Sély-halom (2002); Heves: Bika-Nyilas (2003); Hevesvezekény: Hanyi-ér (1999); Jászivány: Templom-dűlő (1999), Vágó-járás (2004); Pély: Jásziványi-dűlő (1999); Poroszló: Két út köze (2004); Sarud: Csincsa (2002); Tarnaszentmiklós: Görbe-éri-csatorna („HB”) (2014); Hevesi-homok-hát - Tarnaörs: Szent Anna-kápolna (2004) [8287.4], [8386.2], [8386.3], [8387.1], [8387.2], [8388.1], [8389.1], [8389.3], [8486.1], [8487.3], [8487.4], [8488.1], [8488.3], [8587.2]. - Mezsgyékben, határhalmokon, csatornaszegélyekben (Hanyi-ér, Tarna, Gyöngyös-patak, Csincsa) fordul elő. Legtöbbször kis egyedszámú, sérülékeny állományok találhatók (melyeket az elszántás, a vegyszerezés és a mederrendezés veszélyeztet). Jászapáti és Heves között, útmezsgyéből Kitaibel is jelezte a faj előfordulását a második máramarosi útja során (LőKös 2001). A vizsgált terület szomszédságából, a jászdózsai Nagy-halomról ALMÁDI (1985) közölte. A faj a Nagy-Alföld területén nem ritka (MFA online), de a számos előfordulás sok fragmentált élőhelyfoltot takar. (5.A. ábra).

2473. Stipa capillata L.: Hevesi-sík - Erdőtelek: Csörsz-árok (2005); Füzesabony: Csörsz-árok (2002); Kerecsend: Lógó-part (2004) [8287.2], [8288.1], [8288.3]. - Reliktumjellegű löszgyepekből ismert, a vizsgált terület két „hot-spot”-nak is tekinthető lokalitásából (Csörsz-árok és Lógó-part). Mindkét lelőhelyen már irodalmi adatai is ismertek voltak, melyek a felméréseim alapján megerősítést nyertek (ZÓLYOMI 1969, VoJTKó 1994). Kál környékén egykor zavart homokpusztagyepben is előfordult a faj Kitaibel útinaplója alapján (LőKös 2001). A Crisicum területéről számos új adata került közlésre (MoLnÁR 2005, LUKÁcs et al. 2017).

2475. Stipa tirsa Steven em Čelak.: Gyöngyösi-sík - Detk: Kis-Haraszti-dűlő (2009), Tarnócadűlő (3-as főút) (2003); Hevesi-sík - Kerecsend: Fácános-berek (2005), Lógó-part (2004); Mezőtárkány: Salamon-fertő (SzT) (2015!) [8286.4], [8287.2], [8288.1], [8388.2]. - Reliktumjellegű erdőssztyepp-réteken (Kerecsend), szikesekből kiemelkedő löszháton (Mezőtárkány) illetve vasúti- és műútmezsgyén (Detk) észleltük. A 3-as főút mezsgyéjén lévő állományt a visontai bányatelek bővítésével járó Tarnóca-patak „áthelyezése” kedvezőtlenül érintette. A puszta belső részén található előfordulás (Mezőtárkány) az eddig ismert lógóparti állománytól (Deli in VojTKó 2001) délre, közel 13 kilométerre található. Itt a löszhátakon enyhe terjedése is megfigyelhető, melynek oka talán a szárazodó klímában keresendő. A megtelepedés, betelepülés ideje nem ismert, de figyelemreméltó az a tény, hogy közutaktól, vasúti mezsgyéktől távol esik a lokalitás. A Matricum déli előterében, mind a Bükkalján, mind pedig a Mátraalján gyakori (elsősorban felhagyott szőlőkben; lásd BARÁTH 1963, VoJTKó 
2001, SCHMOTZER 2015), a faj déli terjedése valószínűsíthető. A faj újnak tekinthető a Crisicum flórajárásra!

2476. Stipa dasyphylla (Czern. ex Lindem.) Trautv.: Hevesi-sík - Kerecsend: Lógó-part („HB”) (2016) [8287.2], [8288.1]. - Reliktumjellegű száraz gyepekben a Laskó teraszán, löszös talajon. Az előző fajhoz hasonlóan ez is a Matricum déli peremének egyik jellemző Stipa-faja, a vizsgált terület északi részén való előfordulása unikális jelentőségú. Új a Crisicum flórajárásra!

2477. Stipa pennata L.: Hevesi-sík - Füzesabony: Nyárjas (2002); Kerecsend: Lógó-part (2016) [8288.1], [8288.3]. - Sztyeppréten, löszös talajon a Laskó teraszán illetve a 80-as vasúti főpálya mentén, annak rézsủjében. Az utóbbi állomány a vasúti pályatest felújítása során 2015-ben megsemmisült. Tollas árvalányhajat Kitaibel is jelzett a Hevesi-erdőből (GomBocz 1945, MoLNÁR 2008), ennek faji hovatartozása utólag már problematikus (Stipa pennata esetleg $S$. borysteniaca).

2479. Stipa pulcherrima K. Koch: Gyöngyösi-sík - Ludas: 3-as főút mezsgyéje (2009); Hevesisík - Kerecsend: Lógó-part (2016) [8286.4], [8288.1]. - Löszös erdőssztyeppréten illetve a műút mezsgyében fordul elő. Utóbbi helyre a visontai bányatelek bővítése miatt szükségessé vált 3-as számú főút áthelyezését követően telepedhetett be a faj. A faj Matricum-i kisugárzásának tekinthetjük ezen előfordulásokat.

2521. Chrysopogon gryllus (L.) Trin.: Hevesi-sík - Heves: Gazdák-legelője (2002), Radicstagi-legelő (2005); Hevesvezekény: Rakottyás (2005); Jászivány: Templom-dűlő (2018); Kerecsend: Lógó-part (2004) [8287.2], [8288.1], [8487.2], [8487.4], [8488.3]. - Löszgyepekben, enyhén szikesedő hátakon. A vizsgált területen igen szórványos, három jelentősebb elterjedési gócpont köré szerveződik: (1) Laskó- terasza (Lógó-part); (2) Heves - Hevesvezekény környéki löszös gyepek és (3) Jászivány környéke. Kitaibel a Hevesi-erdőből jelezte (GomBocz 1945, MoLNÁR 2008), feltehetőleg itt homokpuszta-gyepen (tisztáson) fordult elő. A Crisicum területén szórványos, inkább a hegylábperemekhez közeli nyugati kistájakon jellemző (Tápió-vidék, Jászság, Hevesi-sík; MFA online). (5.D. ábra).

2522. Bothriochloa ischaemum (L.) Keng: Gyöngyösi-sík - Erk: Gulya-járás (2006), Ludasdűlő (2001), Szőlő-alja-dűlő (2001); Kál: Borjú-járás (2002), Csörsz-árok (2003); Nagyút: Göböl-járás (2005); Tarnaméra: Pusztafogacs (1999); Tarnazsadány: Tarnóca (2005); Hevesi-ártér - Pély: Saj-lapos (2009), Sarud-Saj-foki-főcsatorna (2009); Sarud: Száraz-gát (2003); Újlórincfalva: Kis-Domján (2002); Hevesi-sík - Átány: Szikes-gyep-dúlő (2002); Dormánd: Buda-hát (2002), Szék-kút-dűlő (1999); Erdôtelek: Bencsik (2007), Csörsz-árok (2002), Parlag (2004), Szécsényi-tábla (2008), Tarna (2008); Füzesabony: Nagy-alsó-dúlő (2017), Új-földek (2002); Heves: Gazdák-legelője (2002); Hevesvezekény: Makkai-gyep (2002), Nagy-halom-dűlő (1999); Jászivány: Telki-dủlő (1999), Templom-dúlő (1999); Kerecsend: Lógó-part (2004); Pély: Aranyosi-csatorna (2003), Árendás-legelő (2003), Hosszúfertő (1999), Rakottyás-legelő (2009); Sarud: Belterület /Akácos u./ (2003), Bika-fenék (2002), Cserepes-tábla (2006), Kos-legelő (2002); Tiszanána: Jegyző-tag (2003); Újlőrincfalva: Disznó-legelő (2002); Hevesi-homok-hát - Erdôtelek: Rejner-tábla (2008); Heves: Bazsó-major (2007), Bercsényi-telep (2015), Gergely-telep (2002), Góbis-halom (2003), KisHerceg-tag (2007), Sári-tag (2007); Kál: Első-nyomás (2002), Proletár (2002); Tarnaörs: Bíbic-lapos (2008); Borsodi-Mezőség - Egerfarmos: Barta-állás (2001); Mezőszemere: Baglyas (2002), Nagy-gyep (2002); Szihalom: Rima („HB”) (2016) [8287.3], [8287.4], [8288.1], [8288.2], [8288.3], [8288.4], [8289.1], [8289.3], [8386.2], [8387.1], [8387.2], [8387.3], [8387.4], [8388.1], [8388.3], [8389.3], [8389.4], [8486.2], [8487.1], [8487.2], [8487.4], [8489.1], [8489.2], [8588.1]. - Löszös és homoki gyepekben, melyek természetessége igen változó lehet. A gyepeken kívül előfordulnak állományaik vonalas objektumok, úgymint mezsgyék, csatornapartok, útárkok mentén. A vizsgált területen - a lokalitások számát tekintve - nem tekinthető ritkának, különösen a vizsgált terület déli részén. A Hevesi-erdőből - feltehetőleg annak tisztásairól - már Kitaibel is közli a faj előfordulását (GomBocz 1945, 
MoLNÁR 2008). A Tiszai-Alföldön közepesen elterjedt (MFA online).

2527. Arum orientale M. Bieb.: Hevesi-sík - Átány: Puky-tag (2003) [8388.1]. - Erősen akácosodó kultúrerdőfoltban, Mercurialis perennis társaságában (volt tanyasi iskola helyén). A faj feltehetőleg ültetés következtében került oda, bár a faj hazai kultiválására vonatkozó információk nem ismertek.

2647. Carex michelii Host: Hevesi-sík - Erdôtelek: Csörsz-árok („HB”) (2002) [8288.3]. - Szálkaperjés félszáraz gyepben, a Csörsz-árok egy pontján. A sánc északi kitettségű, akácosodó rézsűjéből került elő. A Kerecsendi-erdőben stabil állománya él (ZóLYOMI 1957, SzUJKó-LACZA 1984).

2659. Epipactis microphylla (Ehrh.) Sw.: Hevesi-sík - Jászivány: Bútelki-erdő (2017), Iványierdő (2004); Borsodi-Mezőség - Egerlövő: Lövői-erdő (2017) [8289.4], [8487.2], [8487.3], [8487.4]. - Telepített kocsányos tölgyesekben fordul elő, azok többnyire erősen árnyékolt részein. A Crisicum területén szórványos, a Jászságban és a Hajduhát keleti peremén élnek legerősebb állományaik (MoLNÁR 2005, MoLNÁR 2011, MFA online).

2666. Epipactis tallosii A. Molnár et Robatsch: Hevesi-ártér - Kisköre: Homok (2018); Sarud: Tisza-tó-töltése (2009); Tiszanána: Tisza-tó-töltése (2009); Hevesi-sík - Pély: Makkos-erdő (1999) [8487.4], [8489.2], [8489.3], [8589.1] - Üde nemes nyárasokból és kocsányos tölgyesekből (Pély) sikerült kimutatni a vizsgált terület déli részéből. Az elmúlt évtizedek szisztematikus kutatásai során a Tiszai-Alföld számos pontjáról került kimutatásra (MoLNÁR 2005, MoLNÁr 2011, TAKÁCS et al. 2014b, LUKÁCS et al. 2017).

2669. Epipactis albensis Nováková et Rydlo: Hevesi-ártér - Tiszanána: Vésefok és környéke (2017) [8489.3] - Fiatal telepített tölgyesben, 5 tő. A Tisza-tó (egykori Csapói-gyümölcsös) területéről is ismert (8389.4; Sulyok J. ex verb.). A Criscum területére eső elterjedése a Tiszató környékére korlátozódik (MoLnÁR 2011).

2673. Epipactis helleborine (L.) Crantz: Gyöngyösi-sík - Boconád: Szi-lapos (2018), Temetődúlő (2017); Hevesi-sík - Egerfarmos: Szentháromság-tábla (2017); Pély: Makkos-erdő (1999); Poroszló: Kis-Fehér-akla (FA) (2009!); Borsodi-Mezőség - Egerlövő: Lövői-erdő (2001) [8289.3], [8289.4], [8387.2], [8387.3], [8389.1], [8487.4]. - Telepített tölgyes foltokban, igen szórványosan a vizsgált területen. Poroszlónál nemesnyáras szegélyében élt, az erdőállomány „összeomlását” követően nem jelentkezett. Az állományok legtöbbször kis egyedszámúak, mely legtöbbször az újkeletű betelepedésre utal. Eddig a homokháti és az ártéri jellegủ kistájakról nem sikerült kimutatni. A többi Epipactis-fajhoz hasonlóan számos új síkvidéki állomány vált ismertté az elmúlt évtizedekben (MOLNÁR 2005, MOLNÁR 2011, MFA online).

2676. Cephalanthera damasonium (Mill.) Druce: Gyöngyösi-sík - Boconád: Csárda-lapos (2017), Temető-dűlő (2017); Erk: Kis-Tarna (2017); Tarnaméra: Nagy-szék (2018), Tarnaörs: Békás-tó (2008), Kis-Tarna (2017); Hevesi-ártér - Kisköre: Mike-part (2017); Tiszanána: Vésefok és környéke (2017); Hevesi-sík - Besenyőtelek: Peresi-dúlő (2017), Peresi-vágottdűlő (2017); Erdôttelek: Felső-teleki-puszta (2017); Füzesabony: Denár-dűlő (2017); Jászivány: Bútelki-erdő (2017), Iványi-erdő (2000); Mezôtárkány: Tárkányi-erdő (2004); Pély: Makkos-erdő (1999); Poroszló: Koppó-hát (2017); Szihalom: Remisz-erdő (2017); Hevesihomok-hát - Erk: Nyárfás (2009, 2017); Tarnaörs: Kút-lapos (2017); Borsodi-Mezőség Egerfarmos: Barta-állás (2001, 2017), Farmosi-útra-járó-dűlő (2001); Egerlövő: Hármas-határ (2017), Lövőii-erdő (2001) [8287.4], [8288.2], [8288.4], [8289.3], [8289.4], [8386.4], [8387.3], [8388.2], [8388.4], [8389.2], [8486.1], [8486.2], [8487.2], [8487.3], [8487.4], [8489.3]. - Telepített tölgyesekben és nyárasokban fordul elő. A 2017-2018. évi intenzív erdőfelmérési munkák eredményeképp számos új lokalitás vált ismertté a 2014-ben publikált térkép adataihoz képest (SснмотZER 2014). A többi orchideaféléhez hasonlóan, a síkvidéki állományok feltártsági foka egyre javul (lásd pl. MolnÁR 2005, MOLNÁR 2011, TAKÁCS et al. 2014b). (3.C. ábra). 
2677. Cephalanthera longifolia (L.) Fritsch: Gyöngyösi-sík - Boconád: Tó-nyilas (2003); Tarnaörs: Békás-tó (2008); Hevesi-ártér: Újlőrincfalva: Székes-hát (2002); Hevesi-sík - Besenyőtelek: Peresi-dűlő (FA) (2015), Peresi-vágott-dűlő (2017), Rátkai-erdő (2000); Füzesabony: Csárda-tető-dúlő (2017), Denár-dűlő (2017); Jászivány: Bútelki-erdő (2017), Iványi-erdő (2004); Kömlő: Bogárzói-tábla (2018), Kocsmáros-fenék (2002); Mezőtárkány: Tárkányi-erdő (2004); Pély: Makkos-erdő (2004); Poroszló: Koppó-hát (2017); Újlőrincfalva: Disznókúti-erdő (2017); Hevesi-homok-hát - Tarnaörs: Bíbic-part (2008); Borsodi-Mezőség - Egerlövő: Lövőierdő (2017) [8288.1], [8288.4], [8289.4], [8387.3], [8388.2], [8388.4], [8389.2], [8389.3], [8389.4], [8486.1], [8486.2], [8487.2], [8487.3], [8487.4]. - Az előző fajhoz hasonló gyakorisággal bukkanthatunk állományaira telepített erdőfoltjainkban (legtöbbször kocsányos tölgyesekben, ritkábban nyárasokban). A jelenlegi Crisicum-i előfordulásának tisztázását számos új publikált adat segíti (lásd MoLNÁR 2011). A C. damasonium-hoz képest a Tiszántúl belső „pusztai" részein jóval szórványosabb, nagyobb területekről hiányzik (MFA online). (3.D. ábra).

2681. Listera ovata (L.) R. Br.: Hevesi-sík - Jászivány: Bútelki-erdő (2017); Borsodi-Mezőség Egerlövô: Lövői-erdő (2017) [8289.4], [8487.2]. - Két erdőtömbből került kimutatásra 2017ben. A Lövői-erdőben telepített tölgyes üde, magyar kőrises állományrészében él egy 80 töves állománya, míg a Bútelki-erdőben hasonló nagyságrendủ állománya él. A vizsgált területen unikális jelentőségü, a Crisicum területén is igen ritka (MoLnÁR 2005, LESKU \& MOLNÁR 2007, MOLNÁR 2011, MFA online). Leggyakoribb a vizsgált területtől nyugatra a Jászságból, ahol számos publikálatlan előfordulása vált ismertté a közelmúltban (Juhász T. felmérései).

2686. Platanthera bifolia (L.) Rchb.: Gyöngyösi-sík - Tarnaörs: Békás-tó (2008); Visznek: Tölgyes (2002); Hevesi-sík - Mezőtárkány: Tárkányi-erdő (2017); Borsodi-Mezőség - Egerlövő́: Lövői-erdő (2001) [8289.4], [8386.3], [8388.2], [8486.1]. - Telepített kocsányos tölgyesekből kerültek elő, többnyire kis egyedszámú (>10 tő) állományaik. A Kerecsendi-erdőben jelenleg is kis egyedszámú, stabil állománya él (SzUJKó-LACZA 1984 ill. saját felmérések). A Lövői-erdőből már ENDES (1985) is jelezte a faj előfordulását. A 2017. évi felmérések során itt a P. chlorantha-val alkotott hibrid (Platanthera $\times$ hybrida Brügger) is előkerült (Molnár V. A. és Sulyok J. azonosította fényképről). A hibrid előfordulása azért is érdekes, mert - jelenlegi ismeretink alapján - a Bükkben és a határoló alföldi kistájakon a $P$. chlorantha előfordulása nem ismert.

2700. Orchis morio L.: Hevesi-sík - Kerecsend: Lógó-part (PA) (2013!) [8287.2], [8288.1]. Csak a Lógó-partot lefedő két flórakvadrátból vált ismertté a faj a vizsgált területről. Cserjésedő löszgyepben, félszáraz gyepben fordul elő, összegyedszáma igen alacsony ( $>10$ tő). A Crisicum területén szórványos, inkább a nagyobb löszhátakkal bíró kistájakon jelentkezik (MOLNÁR 2011, MFA online).

2704. Orchis purpurea Huds.: Gyöngyösi-sík - Tarnaméra: Nagy-szék (2018); Hevesi-sík Jászivány: Bútelki-erdő (2017), Iványi-erdő (2017) [8386.4], [8487.2], [8487.3], [8487.4]. Az elmúlt években sikerült kimutatni a vizsgált területről. A két jásziványi erdőfoltban telepített tölgyesben él: a Bútelki-erdőben erős, közel 300 töves állományát mértem fel, míg a Bútelki-erdőben csak egy tőleveles példányt találtam. Érdekességképp megemlítendő, hogy a hegylábperemeken legtöbbször nyílt gyepekben, felhagyott gyümölcsösökben élő faj „erdőlakóvá" válik a síkságon. Gyakran teljesen árnyékos, humuszban gazdag erdei talajon nő, például a Csáti-erdőből (Mezőcsát) közölt előforduláshoz hasonlóan (lásd Schmotzer \& Sulyok in TAKÁCS et al. 2013). A tarnamérai állomány is új betelepülés eredménye lehet, itt erősen záródáshiányos nemesnyárasban fordul elő a faj. A faj újkeletủ síkvidéki kolonizációját erősíti a szászbereki Berenta-erdőből közelmúltban közölt új előfordulás is (KEVEY 2018).

2705. Orchis militaris L.: Borsodi-Mezőség - Egerlövő: Lövői-erdő (2017) [8289.4]. Telepített tölgyes cserjés szegélyében került elő. A Crisicum területére új, az érintkező bükkaljai részeken - szemben a másik két korábban ismertetett Orchis-fajjal - is nagyon ritka előfordulású (VojTKó 2001, MoLnÁR 2011, MFA online). 


\section{Eredmények}

Az Enumerációban összesen 158 faj és egy hibrid elterjedési adatát közlöm, mely 5.395 recens adat leválogatásából állt össze. Két, flóraatlaszban szereplő saját adat esetében törlésre, illetve javítására vonatkozó javaslatot is tettem (Clematis recta, Symphytum tuberosum fajok esetében). A vizsgálati terület 59 KEF hálóegységet fed le, melyek közül 27 teljes területtel érintett. Jelen tanulmányban 51 kvadrátról közlök adatokat (a kvadrátokra eső átlagos fajszám 21.2\%), melyek megoszlását a 2. ábra mutatja.

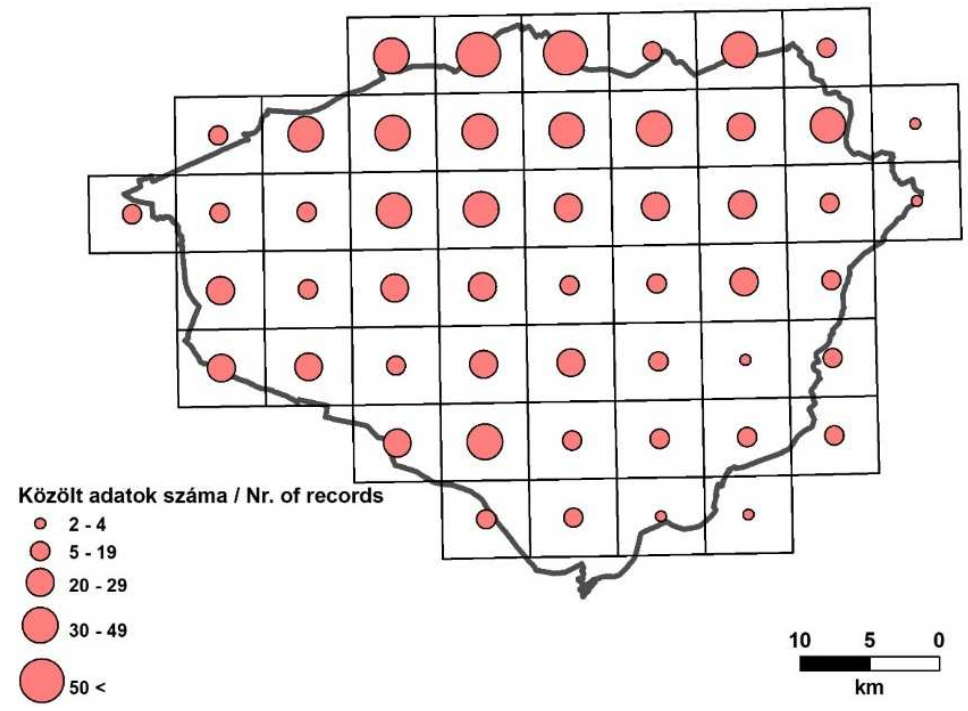

2. ábra A közleményben összefoglalt előfordulási adatok megoszlása a közép-európai flóratérképezés (KEF) hálórendszerének kvadrátjaira vetítve

Fig. 2 Distribution of localities of presented data, projected for the Central European grid system (CEU)

A főbb elterjedési mintázatokat - számos faj elterjedési térképpel - korábban már elemeztem (SchmoTzER 2014). Az újabb vizsgálatok alapján az akkori csoportok további finomításai is elvégezhetők. A három részletesen is értékelt fajcsoport (erdei, erdőssztyepp és száraz gyepekhez köthető sztyeppfajok) néhány indikátor-jellegű képviselője esetében, két olyan, keletnyugati irányú „vonal” (100 méteres izohipsza és a Csörsz-árok) tesztelését is elvégeztem, mely választ adhat az észak - déli flóragrádiensek meglétére, azok mértékére. Ez a két sávként is értékelhető „vonal” a nagytájak, így a flóravidékek lehetséges határsávjának is tekinthető. Az 1. táblázat kiválasztott 25 erdei, erdőssztyepp és sztyepp elem előfordulásait értékeli, annak függvényében, hogy a lokalitások milyen arányban fordulnak elő az értékelt „Vonaltól” északra, illetve ettől délre.

Az összes térképezett előfordulási adatot ábrázoló térképen (2. ábra) az északi területen érzékelhető adat-többlet, nyilván ez csak részben magyarázható a felmérések intenzitásbeli különbségeivel, jórészt növényföldrajzi okok állnak a háttérben.

Az erdei fajok esetében a valódi üde lomberdei fajok (pl. Fagetalia és Querco-Fagetea elemek) igen szórványosak a vizsgált területen. Ennek elsősorban klimatikus okai vannak, de a tájtörténeti múlt sem kedvezett ezek fennmaradásának. A Kitaibel Pál által jellemezett Hevesierdő, valamint a Tarnaörs melletti uradalmi fácános megsemmisült, de - a leírások alapján ezek erdei fajkészlete is leginkább tölgyeserdei (Quercetalia) és erdőssztyepp tölgyes (AceriQuercion) fajokból szerveződött. 
A lomberdei lágyszárú fajok jelentős része csak egy-két lokalitásban jelentkezik, legtöbb esetben 50 év feletti kocsányos tölgy állományokban (Corydalis cava, Elymus caninus /3.H. ábra/, Galium odoratum, Moehringia trinervia, Pulmonaria obscura, Rumex sanguineus, Stachys sylvatica, Stellaria holostea, Symphytum tuberosum). Gyakoribbnak (több mint 5 lokalitásban) csak a generalista Brachypodium sylvaticum (3.B. ábra) és Poa nemoralis mutatkozik. Az erdei elemek előfordulásának több mint $80 \%$-a a vizsgált terület hét nagyobb erdőterületéhez kötődik (Rátkai-erdő /Besenyőtelek/, Tárkányi-erdő /Mezőtárkány/, Prónay-erdő /Mezőszemere/, Lövői-erdő /Egerlövő/, Makkos-erdő /Pély/, Iványi- és Bútelki-erdő /Jászivány/). Figyelemreméltó tény, hogy ezen erdőterületek területe 20 és 126 hektár közötti és a tájtörténeti térképek tanúsága szerint mezőgazdasági terület első erdősítésével jöttek létre (legtöbbször szántókon).

Külön elterjedési mintázat-típust képviselnek a vízfolyások mentén a Mátrából terjedő erdei elemek (pl. Campanula rapunculoides, Corydalis solida, Galanthus nivalis), ezek szinte kivétel nélkül a vizsgált terület legészakibb részén, a Tarnóca-patak mentén koncentrálódnak. Itt gyengülő flórautánpótlással számolunk, mivel a Visontai bányatelek bővítésével a Tarnócapatak medre többször is áthelyezésre került, annak természetessége (parti fás növényzet hiánya miatt) igen leromlott.

Egyes meglévő erdei fajok táji szintű honossága kérdéses az atipikus lelőhelyeik alapján (pl. Mercurialis perennis, Arum orientale, Hedera helix, Ribes uva-crispa), míg bizonyos - már inkább tölgyerdei fajoknál - egyaránt találunk honos, illetve szubspontán előfordulásokat is (pl. Acer tataricum, Convallaria majalis, Polygonatum latifolium). Utóbbi két faj esetében számos temetőkerti előfordulást is dokumentáltam. Elszórtan a Carpinus betulus és a Quercus cerris is megjelenik, de ezeket - a Kerecsendi-erdőtől délre - nem tekintem honosnak. Megjegyzendő azonban, hogy a terület átmeneti klimatikus adottságai miatt számos új sikeres cseres erdőtelepítés is történt a puszta belső részeiben is.

Külön fajcsoportot képeznek azok a - jobbára tölgyes övi - erdei zavarástűrő elemek, melyek szórványosan jelennek meg a területen (Alliaria petiolata, Geranium robertianum, Chaerophyllum temulum, Lactuca quercina /3.I. ábra/, Mycelis muralis /3.J. ábra/, Myosotis sparsiflora, Galeopsis pubescens, Lamium maculatum, Inula conyza, Lactuca quercina, Lapsana communis). Míg a vizsgált terület északi részén erdőterületeken kívül, például cserjésekben, mezsgyékben, patakok mentén is előfordulnak, addig dél felé egyre inkább obligát erdei fajként viselkednek. Hasonló megállapításokat tehetünk az adatközlésbe bevont három lián (stratégiájú) növény (Clematis vitalba /3.E. ábra/, Cucubalus baccifer /3.F. ábra/, Fallopia dumetorum) esetében is. A hegyvidéki vágásnövényzet jellegzetes tagja, a Chamaenerion angustifolium szünantróp élőhelyről (kavicsbányából) került elő.

Az erdőterületek sajátos fajkészletéhez tartoznak egyrészt a jól kolonizáló orchidea- és páfrányfélék. Az erdei kosborféléket 10 faj és egy hibrid képviseli, melyek közül a Cephalanthera damasonium (3.C. ábra), a C. longifolia (3.D. ábra) és az Epipactis helleborine nem tekinthető régiósan ritkának, különösen, ha az erdőterületek kiterjedését és térbeli mintázatát is figyelembe vesszük. Érdekességképp megemlítendő, hogy a hegylábperemeken legtöbbször nyílt gyepekben, felhagyott gyümölcsösökben élő Orchis purpurea „erdőlakóvá” válik a síkságon és nudum jellegű, teljesen árnyékos tölgyes erdőrészletekben nő a jásziványi Bútelki- és Iványierdőben. A páfrányokat a Dryopteris filix-mas (3.G. ábra) és a D. carthusiana képviseli, a lokalitásonkénti alacsony egyedszám itt is a nem túl régi kolonizációra utalhat.

Az erdei fajok jelenléte a tájban, a meglévő, jobbára honos fafajú erdőterületekhez kötődik. A mikroklimatikus és talajtani adottságok lehetővé teszik egyrészt megtelepedésüket, másrészt fennmaradásukat. Klasszikus értelemben vett erdőrefugiumok nem fordulnak elő a vizsgált területen, néhány faj esetében egykori fás mezsgyék megőrző szerepét azonban feltételezzük (lásd a Corydalis cava előfordulását a Tárkányi-erdőben). Bár egyes fajok hangsúlyosan a vizsgált terület északi részén gyakoribbak, a két vizsgált vonaltól északra és délre is előfordulnak állományaik. 

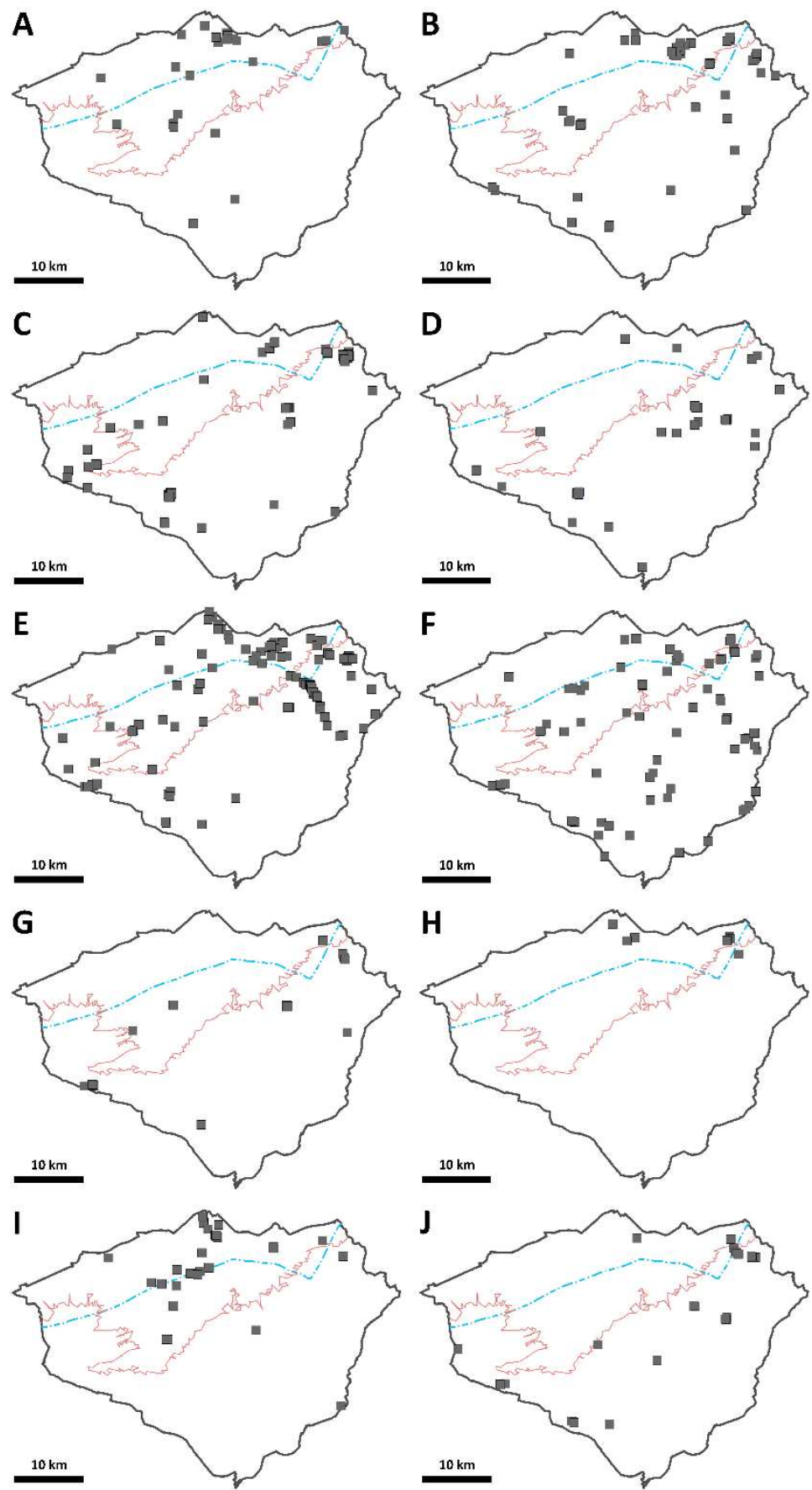

3. ábra Néhány erdei faj elterjedése a vizsgált területen

(folytonos vonal = Csörsz-árok vonala; szaggatott vonal = $100 \mathrm{~m}$ izohipsza vonal)

Fig. 3 Distribution of some forest species in the studied area

(continuous line $=$ Csörsz Ditch; dashed line $=100 \mathrm{~m}$ isoline)

A - Alliaria petiolate; B - Brachypodium sylvaticum; C - Cephalanthera damasonium; D - Cephalanthera longifolia; E - Clematis vitalba; F - Cucubalus baccifer; G - Dryopteris flix-mas; $\mathrm{H}$ - Elymus caninus; I - Lactuca quercina; J - Mycelis muralis 
Az 1. táblázatban ismertetett 6 erdei faj esetében egyértelmű grádiensszerű elterjedést nem észleltünk, erősen diszperz mintázatot mutatnak a vizsgált területen. A fajok jelenlétét egyértelműen az erdőterületek helyzete határozza meg, ezzel is magyarázható, hogy a vizsgált vonalaktól legtöbbször délre gyakoribbak (ahol paradox módon, a telepítések miatt nagyobb az erdősültség mértéke).

Az erdőssztyepp-fajok csoportja nem rendelkezik egységes élőhelypreferenciával. Viszonylag kevés olyan faj van, mely kizárólag zárt erdőkhöz kötődik. Ezek közül is érdemes kiemelni a Doronicum hungaricum és a Pulmonaria mollis mezőszemerei állományait. Inkább erdőlakó a Polygonatum latifolium is, de ez már rontott akácosokban, származékerdőkben is előfordul (4.G. ábra). Jóval gyakrabban fordulnak elő az erdőssztyepp-fajok képviselői erdőszegélyekben, cserjés mezsgyéken, de akár teljesen fénygazdag élőhelyeken is (pl. löszgyepekben). Ezek jelentős egyedszámban és számos lokalitásban fordulnak elő. JAKUCS Pál (1961) által összeállított „erdőssztyepp /WS/-katalógus” alapján 31 erdőssztyepp faj fordul elő a területen. Ezt a listát kiegészítettem további 9 olyan fajjal is, melyek a terepi tapasztalataim alapján, a vizsgált területen és az érintkező hegylábakon erdőssztyepp fajként viselkednek. A tételes erdőssztyepp fajlistát a 2. táblázat ismerteti. Ebben a táblázatban feltüntettem a két legfontosabb „reliktumőrző” helyen, a kerecsendi Lógó-parton, illetve a Csörsz-árkon (annak is terepen jól azonosítható Tarna és Laskó patakok közötti szakaszán) előforduló erdőssztyepp-fajokat (Lógó-part: 33 faj; Csörsz-árok: 31 faj). Magas a mindkét lokalitásban előforduló közös fajok száma (összesen 24 faj a 40-ből). A vizsgált terület növényföldrajzi és természetvédelmi szempontból legjelentősebb értéket az a 17 erdőssztyepp faj alkotja, melyek csak e két lokalitásban, vagy ezek egyikén fordul elő a vizsgált területen (ezeket kövér betűvel jelöltem a táblázatban). Ezek legtöbbje a Crisicum területén is igen sporadikus előfordulású, számos faj jelenleg csak innen ismert a flórajárásából. Míg a Lógó-part esetében a közvetlen flórakapcsolat megvan a Laskó-patak teraszán található Kerecsendi-erdővel (vagy másképpen Berek-erdővel), a Csörsz-árok már jóval inkább izolátum jellegű. Itt a flórautánpótlást a lefutó patakok jelenthetik (Tarna, Tarnóca, Bene-patak, Laskó), mely néhány faj elterjedési mintázatán jól tetten is érthető (lásd Veronica teucrium elterjedési térképét, SCHMOTZER 2014).

A Csörsz-árok az erdőssztyepp fajok elterjedése szempontjából kiemelkedő fontosságúnak tekinthető. Számos olyan faj van, melynek az előfordulásai szinte kizárólag a Csörsz-vonalára és az ettől északra helyezkedő hegylábperemhez közelebbi részekre esnek. Erre legjobb példaként a Brachypodium pinnatum, a Campanula bononiensis, a Clematis recta (4.B. ábra) és a Vicia tenuifolia (4.I. ábra) elterjedése, amely fajoknál ez a számarány $80 \%$ feletti (egyeseknél $100 \%)$. Hasonló északi denzitás-sűrűséget mutat az Acer tataricum (4.A. ábra), a Hylotelephium telephium (4.C. ábra), a Lathyrus latifolius (4.D. ábra) , a Melica altissima (4.E. ábra) a Rosa gallica (4.H. ábra) és a Vincetoxicum hirundinaria (4.J. ábra) elterjedési térképe is. Az erdőssztyepp-fajok általában a sáncárok északi lejtésű rézsűjében fordulnak elő, többnyire pusztai cserjések, illetve a már ZóLYOMI (1957) által is jelzett molyhos tölgyes facsoportok alatt.

A két vizsgált vonal egymással nem párhuzamos, a 100 méteres izohipsza a Hevesi-homokhát területén 10-12 kilométerrel délebbre fut, mint a Csörsz-árok. A homokterületek - még erősen leromlott állapotban is - jobb megőrző képességgel rendelkeznek, mint a kötött talajú pusztai területrészek. Ez a talajadottságokon túl, a mozaikosabb tájhasználatnak is köszönhető. A homokterületen számos erdei- és erdőssztyepp-faj dél felé hatolhatott a Mátra és a Tarna-völgy irányából, ezt a Kitaibel leírásából ismert - mára elpusztult - Hevesi-erdő egykori fajkészlete is igazolja. Ma azonban ezt már csak egyes erdőssztyepp és tölgyes fajok (Arabis glabra, Hylotelephinum telephinum, Origanum vulgare) mezsgyékre és parlagokra szorult állományai igazolják. 

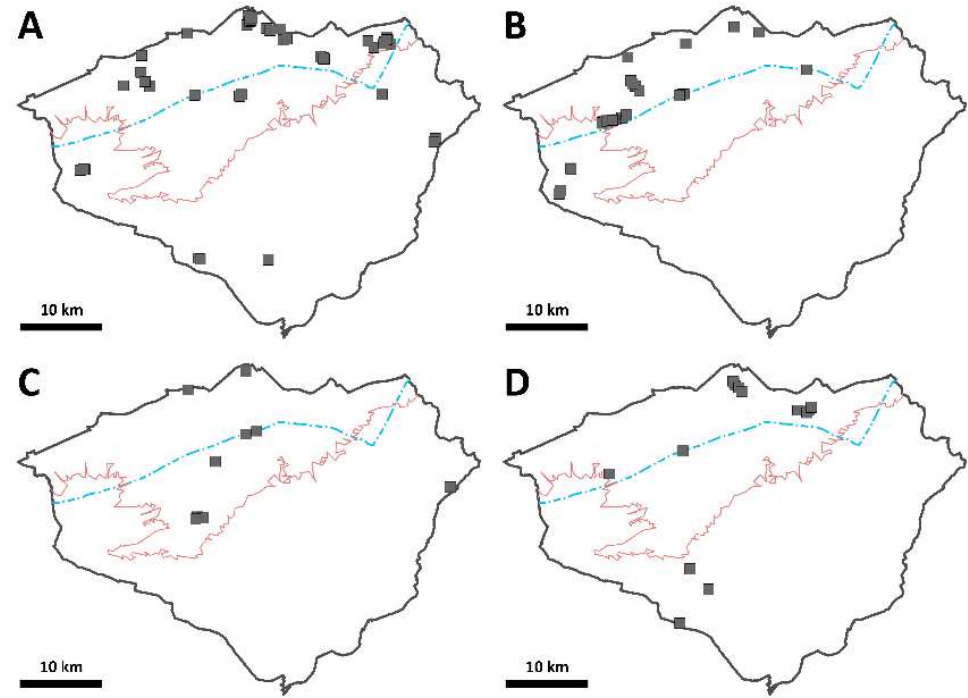

D
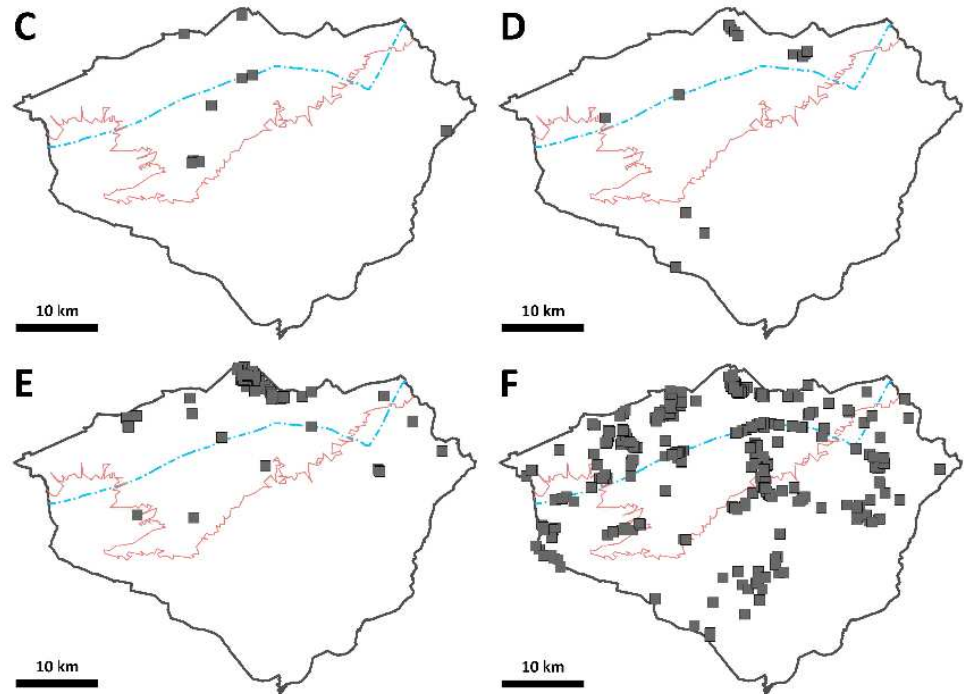

$\mathbf{F}$
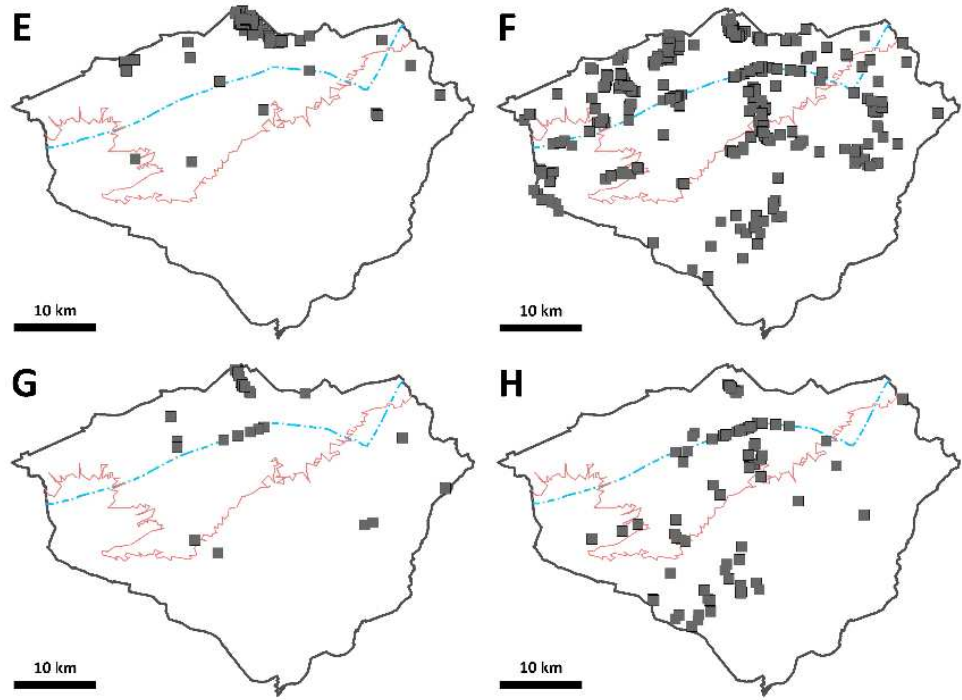

H
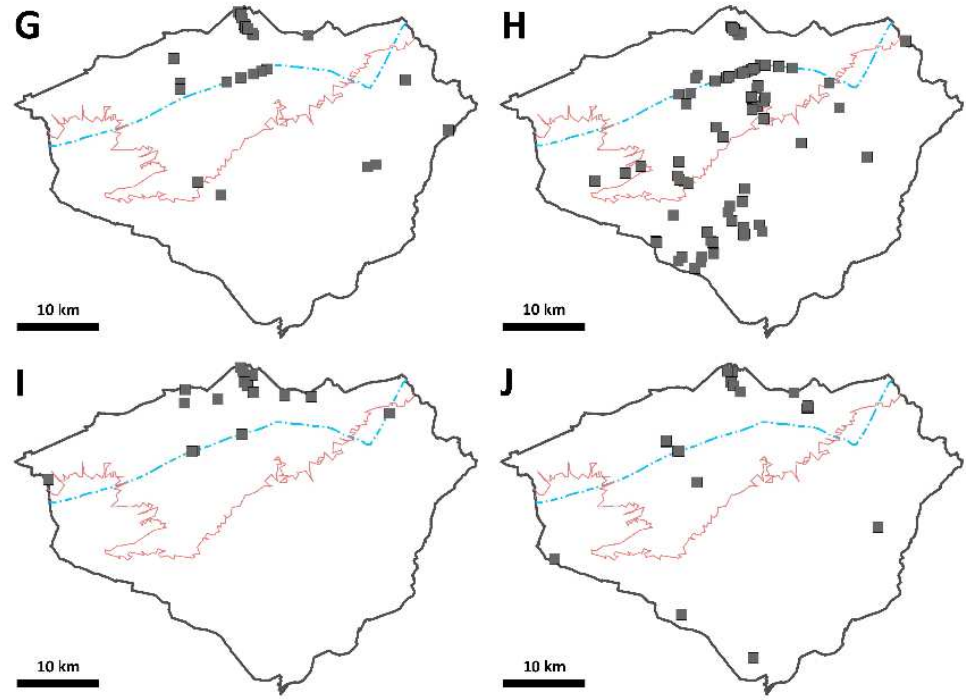

4. ábra Néhány erdőssztyepp faj elterjedése a vizsgált területen

(folytonos vonal $=$ Csörsz-árok vonala; szaggatott vonal $=100 \mathrm{~m}$ izohipsza vonal)

Fig. 4 Distribution of some forest-steppe species in the studied area (continuous line $=$ Csörsz Ditch; dashed line $=100 \mathrm{~m}$ isoline)

A - Acer tataricum; B - Clematis recta; C - Hylotelephinum telephinum; D - Lathyrus latifolius; E - Melica altissima; F - Phlomis tuberosa; G - Rosa gallica; H - Thalictrum minus; I - Vicia tenuifolia; $\mathrm{J}$ - Vincetoxicum hirundinaria 
A részletesen elemzett Phlomis tuberosa (4.F. ábra) és Thalictrum minus (4.H. ábra) fajok jóval szélesebb elterjedéssel bírnak a területen, ezeknél a Csörsz-árokhoz, illetve a 100 méteres izohipsza vonalhoz viszonyított grádiensszerű elterjedési különbségek nem észlelhetők (előfordulásaik csak 45 illetve 17 százaléka esik a Csörsz-ároktól északra). Állományaik a puszta belső részein is megtalálhatók, azonban dél felé a Hevesi-ártér kistáj határánál egy újabb elterjedési határvonal húzható meg. Ez jórészt a klimatikus változásokkal (feltehetően az aszályos időszak hosszának növekedése) magyarázható, melyhez a talajtani adottságok (az egykori ártéren a kötött öntéstalajok a jellemzőek) is kapcsolódtak. Ez a második grádiens határvonal a legtöbb faj esetében kimutatható, az ártéri kistájat már legtöbbször csak szünanatróp helyeken tudják meghódítani az erdőssztyepp fajok (lásd a Vincetoxicum hirundinaria déli előfordulásait).

1. táblázat Indikátor növényfajok észlelt előfordulásai a Csörsz-ároktól és a 100 méteres izohipsziától északra (E = erdei-; ESZ = erdőssztyepp-; Sz = sztyepp faj)

Table 1 Occurrences of indicator species northward to the Csörsz Ditch and the $100 \mathrm{~m}$ isoline ( $E$ = forest species; ESZ = forest-steppe species; $S Z$ = dry grassland 'steppe' species)

\begin{tabular}{|c|c|c|c|c|}
\hline $\begin{array}{l}\text { Élőhely } \\
\text { csoport / } \\
\text { Habitat } \\
\text { group }\end{array}$ & Fajnév / Species name & $\begin{array}{c}\text { Lelőhelyek } \\
\text { száma / } \\
\text { Number of } \\
\text { localities }\end{array}$ & $\begin{array}{c}\text { ebből Csörsz-ároktól } \\
\text { északra (db/\%) / } \\
\text { occurrances north } \\
\text { from Csörsz Ditch } \\
\text { (ps/\%) }\end{array}$ & $\begin{array}{c}\text { ebből a } 100 \text { m-es } \\
\text { izohipsziától } \\
\text { északra }(\mathrm{db} / \%) / \\
\text { occurrances north } \\
\text { from } 100 \mathrm{~m} \text { isoline } \\
(\mathrm{ps} / \%)\end{array}$ \\
\hline$E$ & Brachypodium sylvaticum & 29 & $13 / 44.8$ & $15 / 51.7$ \\
\hline $\mathrm{E}$ & Cephalanthera damasonium & 24 & $3 / 12.5$ & 8 / 33.3 \\
\hline $\mathrm{E}$ & Cephalanthera longifolia & 19 & $2 / 10.5$ & $3 / 15.8$ \\
\hline E & Dryopteris filix-mas & 10 & $1 / 10.0$ & $3 / 30.0$ \\
\hline E & Lactuca quercina & 21 & $14 / 66.6$ & $18 / 85.7$ \\
\hline $\mathrm{E}$ & Mycelis muralis & 14 & $3 / 21.4$ & $3 / 21.4$ \\
\hline ESZ & Brachypodium pinnatum & 13 & $12 / 92.3$ & $13 / 100$ \\
\hline ESZ & Campanula bononiensis & 14 & $13 / 92.9$ & $14 / 100$ \\
\hline ESZ & Clematis recta & 15 & $12 / 80.0$ & $12 / 80.0$ \\
\hline ESZ & Melica altissima & 29 & $22 / 75.9$ & $24 / 82.8$ \\
\hline ESZ & Phlomis tuberosa & 154 & $70 / 45.5$ & $81 / 52.6$ \\
\hline ESZ & Polygonatum latifolium & 14 & $9 / 64.3$ & $14 / 100$ \\
\hline ESZ & Rosa gallica & 12 & $6 / 50.0$ & 7 / 58.3 \\
\hline ESZ & Thalictrum minus & 47 & $8 / 17.0$ & $24 / 51.1$ \\
\hline ESZ & Vicia tenuifolia & 11 & $10 / 90.9$ & $10 / 90.9$ \\
\hline ESZ & Vincetoxicum hirundinaria & 13 & $8 / 61.5$ & $9 / 69.2$ \\
\hline SZ & Agropyron cristatum & 18 & $4 / 22.2$ & $3 / 16.7$ \\
\hline SZ & Artemisia pontica & 70 & 18 / 25.7 & $17 / 24.3$ \\
\hline SZ & Dianthus collinus & 8 & $8 / 100$ & $8 / 100$ \\
\hline SZ & Inula germanica & 10 & $5 / 50.0$ & $5 / 50.0$ \\
\hline SZ & Ornithogalum brevistylum & 139 & $61 / 43.9$ & $65 / 46.8$ \\
\hline SZ & Peucedanum alsaticum & 71 & $55 / 77.5$ & $53 / 74.6$ \\
\hline SZ & Potentilla patula & 48 & $8 / 16.7$ & $16 / 33.3$ \\
\hline SZ & Seseli varium & 49 & $22 / 44.9$ & $32 / 65.3$ \\
\hline SZ & Thlaspi jankae & 35 & $27 / 77.1$ & $33 / 94.3$ \\
\hline
\end{tabular}


2. táblázat A vizsgált terület két reliktumörző lokalitásában, a Lógó-parton és a Csörsz-árkon előforduló erdőssztyepp fajok listája (+ = jelenlét, (+) = a csak archív előfordulási adat; a vizsgált területen csak ezen lokalitásokban előforduló fajokat kövér betűvel jelöltük)

Table 2 Forest steppe species occurring in two relict locations, Lógó-part and Csörsz Ditch $(+=$ presence; $(+)=$ only literature data; bold letters indicate species occurring only in these locations in the studied area)

\begin{tabular}{|c|c|c|}
\hline $\begin{array}{c}\text { Fajnév (*besorolás JAKUCS } \\
1961 \text { alapján) / Species name } \\
\text { (*categorisation after JAKUCS } \\
1961 \text { ) }\end{array}$ & $\begin{array}{l}\text { Előfordulás a Lógó- } \\
\text { parton / Occurrence } \\
\text { on Lógó-part }\end{array}$ & $\begin{array}{l}\text { Előfordulás a Csörsz- } \\
\text { árkon / Occurrence on } \\
\text { Csörsz Ditch }\end{array}$ \\
\hline Anemone sylvestris * & & + \\
\hline Betonica officinalis* & + & + \\
\hline Bromus inermis* & + & + \\
\hline Campanula bononiensis & + & + \\
\hline Carex michelii $*$ & & + \\
\hline Chamaecytisus virescens & & + \\
\hline Cerasus fruticosa & + & + \\
\hline Clematis recta* & + & + \\
\hline Dictamnus albus* & + & \\
\hline Fragaria viridis* & + & + \\
\hline Genista tinctoria ssp. elata* & + & \\
\hline Geranium sanguineum * & & + \\
\hline Hylotelephium telephium * & + & + \\
\hline Hypochoeris maculata* & + & \\
\hline Inula germanica* & + & + \\
\hline Inula hirta* & + & $(+)$ \\
\hline Iris graminea & + & \\
\hline Iris variegata* & + & + \\
\hline Lathyrus lacteus* & + & \\
\hline Melica altissima $*$ & & + \\
\hline Nepeta pannonica * & + & $(+)$ \\
\hline Peucedanum alsaticum* & + & + \\
\hline Peucedanum cervaria* ${ }^{*}$ & + & + \\
\hline Peucedanum officinale ${ }^{*}$ & + & \\
\hline Phlomis tuberosa* & + & + \\
\hline Polygonatum latifolium & & + \\
\hline Polygonatum odoratum* & & + \\
\hline Potentilla recta* & + & \\
\hline Pseudolysimachion spurium * & + & \\
\hline Pulmonaria mollis * & + & \\
\hline Ranunculus polyanthemos $*$ & + & + \\
\hline Rhamnus catharticus* & + & + \\
\hline Rosa gallica & + & + \\
\hline Tanacetum corymbosum & + & + \\
\hline Teucrium chamaedrys * & + & + \\
\hline Thalictrum minus & + & + \\
\hline Thesium linophyllon* & + & + \\
\hline Trifolium montanum * & + & + \\
\hline Vicia tenuifolia & + & + \\
\hline Vincetoxicum hirundinaria * & + & + \\
\hline összesen / sum: & 33 & 31 \\
\hline
\end{tabular}

A vizsgált területen előforduló sztyeppfajok elsősorban xerotherm élőhelyeket népesítenek be. Különösen magas a pannon, pontuszi-pannon elterjedésű fajok aránya, ezek részben közösek az érintkező Matricum-i részekkel, részben pedig a jellemző pusztai flóra képviselői.

A dombvidéki elterjedési súlyponttal rendelkező fajok között azok a legértékesebbek, melyek az Crisicum területére is már csak pár lokalitásban lépnek ki. Egyes fajok az érintkező 
Bükk- és Mátraaljai területeken még gyakoriak, a síkra kilépve azonban igen szórványossá válnak. Erre az elterjedési mintázatra jó példa az Achillea nobilis subsp. neilreichii, Dorycnium spp., Elymus hispidus, Inula ensifolia, Luzula campestris, Lychnis viscaria, Ranunculus illyricus, Sanguisorba minor, Stachys recta, Stipa capillata, Stipa dasyphylla, Teucrium chamedrys (5.J. ábra), Trifolium alpestre, T. ochroleucon, Vinca herbacea) fajok elterjedése. Más fajok az érintkező dombvidéki részeken sem túl gyakoriak, síkvidéki előfordulásuk unikális jelentőségű (pl. Arenaria procera, Campanula glomerata, Echium maculatum, Galium glaucum, Hesperis tristis, Lathyrus lacteus, Prunella grandiflora, Pseudolysimachion spurium, Scorzonera purpurea, Stipa dasyphylla, S. pulcherrima).

Ismertek olyan fajok is, melyek a vizsgált terület északi részén - a számukra alkalmas, nem túl nagy kiterjedésű élőhelyfoltokban - több ponton is előfordulnak. A Thlaspi jankae, mint prematricumi endemizmus a Dormánd környéki löszös hátakig és a Tarna mentén Tarnaörs Jászdózsa térségéig lehatol, azonban állományaik jelentős része a Csörsz-ároktól (77\%), illetve a 100 méteres izohipsza vonaltól (95\%) északra található. A Dianthus collinus lokalitásai kivétel nélkül a vizsgált vonalaktól északra kerültek elő (5.E. ábra). Gyakori elemnek tekinthető hegylábperemek felé még a Peucedanum alsaticum, mely a vizsgált vonalaktól délre már csak a Tarna (itt még tömegesen) és a Laskó patakok (csak szórványosan) mentén hatol délre. Jóval ritkább a $P$. cervaria, ez a jelzett reliktumőrző helyeken kívül már csak az Eger-patak és a Tarna mentén fordul elő, elterjedésének tengelye egybeesik a Csörsz-árokkal.

A sztyeppfajok közül ismertek olyanok, melyek széles körben előfordulnak a vizsgált területen (pl. Artemisia pontica /5.B ábra/, Astragalus cicer, Centaurea scabiosa agg. alfajai /5.C. ábra/, Ornithogalum brevistylum /5.F. ábra/), esetükben a két vonal grádiens mintázati törést nem jelez. Ezen fajok legtöbbször jó terjedési képességgel rendelkeznek, a nagyobb forráspopulációk a mezsgyék (mint terjedési útvonalak mentén) révén összeköttetésben állnak. A mezsgyéken kívül a vízfolyásokat kísérő csatornaoldalak is megfelelő élőhelyet biztosítanak.

A löszgyepekhez jobban kötődő fajok ettől eltérő mintázattal rendelkeznek. A gyakoribb elemek már inkább a vizsgált vonalaktól délre a jellemzők (pl. Agropyron cristatum (5.A. ábra), Bothriochloa ischaemum, Potentilla patula /5.G. ábra/). Ezt a mintázatot néhány, a tájban már ritka elem is követi (pl. Cruciata pedemontana). Egyes fajok állományai a két vizsgált vonaltól északra és délre közel egyenlő arányban fordulnak elő, míg a Dianthus pontederae és a Seseli varium /5.I. ábra/ főleg löszhátakon, gyepekben a jellemző, addig például az Inula germanica elsősorban délen mezsgyékhez, míg északon löszgyepekhez köthető. Kirajzolódnak olyan elterjedési mintázatok is, ahol az adott fajnak egy vagy több kisebb, jól körülhatárolható elterjedési gócpontjai váltak ismertté. Erre példaként a Seseli annuum és a Chrysopogon gryllus regionális elterjedése szolgál. Táji szinten mindkét faj sporadikus, de pédául a Seseli annuum állományának jelentős része a Nagy-Hanyi puszta környékén (Dormánd és Erdőtelek határában) koncentrálódik (5.H ábra) Három jelentősebb feldúsulási gócpontot mutat a Chrysopogon gryllus előfordulása (5.D ábra).

A száraz gyepekhez köthető sztyeppfajok többségénél a jelenleg tapasztalható diszperz elterjedés hátterében a nagyfokú tájátalakító emberi tevekénység (lásd gyepfeltörés, cserjések, mezsgyék felszámolása, idegenhonos fajok előretörése stb.) áll. Figyelembe kell venni azt is, hogy egyes fajok állományainak fragmentálódásával párhuzamosan a visszatelepedés lehetőségei is korlátozottá váltak. Nem véletlen, hogy a kipusztult fajok jelentős része száraz gyepekhez köthető sztyepp- vagy erdőssztyeppfaj (lásd SCHмотzer 2014). A Carduus hamolosus a jelenlegi ismereteink alapján, mindössze a vizsgált terület három pontján fordul elő, de pontosan Kitaibel leírásaiból tudjuk, hogy 200 éve, mint jellemző „nem ritka löszgyomnövény” fordult elő a területen. 

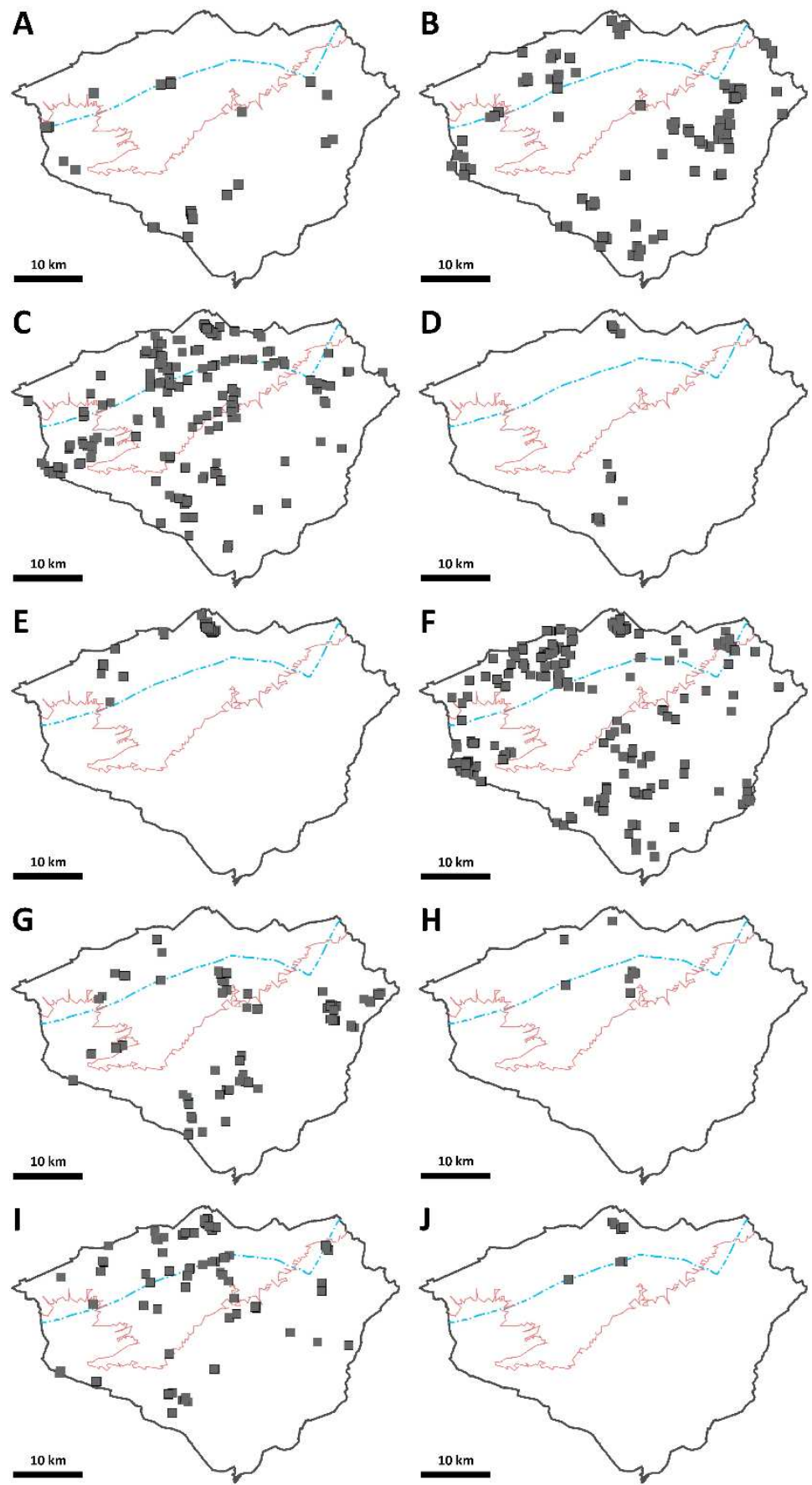

5. ábra Néhány száraz gyepekhez köthető sztyeppfaj elterjedése a vizsgált területen (folytonos vonal = Csörsz-árok vonala; szaggatott vonal $=100 \mathrm{~m}$ izohipsza vonal)

Fig. 5 Distribution of some dry grassland steppe species in the studied area (continuous line $=$ Csörsz Ditch; dashed line $=100 \mathrm{~m}$ isoline)

A - Agropyron cristatum; B - Artemisia pontica; C - Centaurea scabiosa agg.; D - Chrysopogon gryllus; E - Dianthus collinus; F - Ornithogalum brevistylum; G - Potentilla patula; H - Seseli annuum; I - Seseli varium; J - Teucrium chamaedrys 


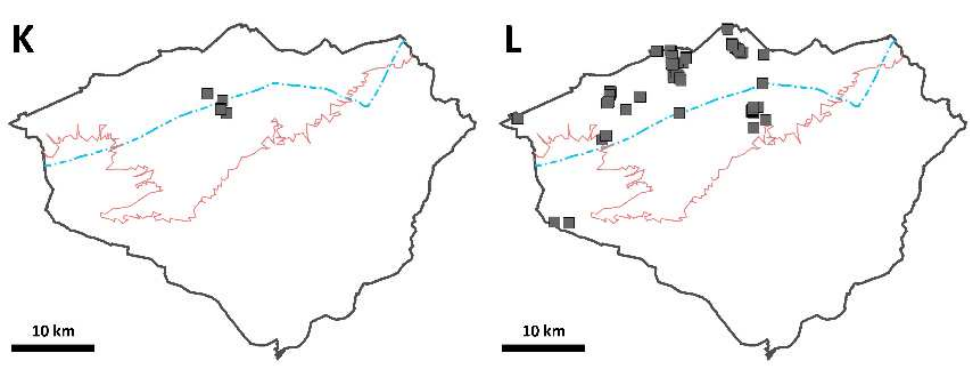

5. ábra (folytatás az előző oldalról)

Fig. 5 (continuation from the previous page)

$\mathrm{K}$ - Silene otites; L - Thlaspi jankae

Összefoglalásképp megállapíthatjuk, hogy a vizsgálat tárgyát képező - a hegylábperemek és a Tisza közé eső - síkvidéki területek igen alkalmasak regionális léptékű chorológiai vizsgálatokra. A déli határt képező Tisza-völgy elsősorban az erdőssztyepp fajok számára nem permeábilis, itt éles határ mutatkozik. A Crisicum vizsgálati területet érintő részének északi határvonalának - pontosabban határzónájának - kijelölését egyrészt domborzati paraméterek (lásd 100 méteres izohipsza vonal) meg lehet tenni. A hegylábperek (Mátra- és Bükkalja) átmeneti sávjának déli határa egészen a Csörsz-árok vonaláig lenyúlik, számos kollin elterjedésű faj ettől délebbre nem terjed, vagy csak nagyon szórványos előfordulású. Az északi részek közvetlen kapcsolattal rendelkeznek még a hegylábi területekkel (lefutó teraszok, patakok révén), mely a flórára is kihatással van. A puszta belső részein, ahol jobbára mezsgyékre szorulva fordulnak elő a száraz gyepi sztyepp- és erdőssztyepp-elemek, ott a regeneráció képessége eleve limitált. Az izolátumok felszámolásával, a visszatelepedés lehetőségei is igen korlátozottak. A korábban már ismert „reliktumőrző” helyeken (pl. Lógó-part, Csörsz-árok) túl számos olyan lokalitást tártam fel, melyek az erdőssztyepp és a pusztai flóra szempontjából fontosak. E helyek közül kiemelhető a nagyúti Bene-patak terasza (Kis-erdő és Sár-rét dűlők), a Kápolna és Kompolt melletti gyepek, de egyes pusztai löszös hátak is számos faj megőrzésében játszanak fontos szerepet (pl. Dormánd: Nagy-Hanyi; Pély - Jászivány szikes pusztái stb.).

Az igazi erdei fajok ezzel szemben inkább diszperz mintázatot mutatnak, képviselőik a tájban szigetként jelentkező erdőtömbökhöz köthetők. Az erdei fajok esetében is kiemelkedő jelentőséggel bírnak a hegységekből lefutó patakok, amelyek a flórautánpótlást biztosítják, ezek jelentősége és szerepe dél felé erősen lecsökken.

A klimatikus grádiensek által meghatározott flóragrádienseket az ember tájátalakító tevékenysége is erősen befolyásolta. A természetföldrajzi (klíma, talaj) és a táji adottságok és maga a tájhasználat közvetlenül hat is egymásra. FRISNYÁK et al. (2017) megállapították, hogy a kultúrtájak magterületei ősi telepítő vonalakon alakulnak ki. A kultúrtájak magterületei azok a térpontok, ahol az emberek elsődlegesen megtelepedtek és kialakították életterüket. Az általuk lehatárolt négy telepítővonal közül a vizsgált területen a felső grádiensvonal az ármentes síkságok és a dombságok érintkezési sávját alkotja (ezt sokszor „vásárvonalként” is definiálják), míg a Tisza-völgynél maga az egykori ártér pereme jelöli ki a második ilyen vonalat. Ezek határozták meg a településszerkezet és az úthálózat kialakulását, fejlődését. Mint a kiértékelésből is látjuk, hogy a fajok többsége regionális areahatárával követi ezeket az észak-déli grádienseket, melyek megléte legjobban a kollin jellegű fajok elterjedésében mutatkozik meg. A makroklimatikus adottságok a Crisicum északi peremén kelet - nyugat irányában kevés változnak, így ilyen irányú grádienseket nem tudtunk megállapítani. A regionális kelet - nyugati eltéréseket itt már leginkább a talajtani adottságok határozzák meg (ez leginkább a szikesek fajkészletében nyilvánul meg). 


\section{Köszönetnyilvánítás}

Itt szeretném köszönetemet kifejezni, minden adatközlőnek, aki rendelkezésre bocsátotta publikálatlan adatait (nevüket lásd az Anyag és módszer fejezetben). Illesse külön köszönet Holló Sándort (Eger, BNPI), aki az elmúlt években több sáncárok szakaszra hívta fel a figyelmemet. Tóth Lászlónak (Eger, BNPI) és Vojtkó Andrásnak (Eger, EKE) köszönöm egyes nehezen hozzáférhető irodalmak beszerzésében való közreműködését. Az adatok összerendezésében nyújtott segítségét köszönöm Sulyok Józsefnek és Kalmár Zsuzsannának (mindketten Eger, BNPI). Köszönöm továbbá Kun András és a másik, anoním lektor kézirathoz fúzött értékes észrevételeit, javaslatait.

\section{Irodalom}

ALMÁDI L. (1984): Adatok Tarnaörs környékének flórájához. - Folia Historico-Naturalia Musei Matraensis 9: 15-17.

ALMÁDI L. (1985): Adatok az Észak-Jászság flórájához. - Folia Historico-Naturalia Musei Matraensis 10: 25-30.

AmBRus B. (1993): Macskahere (Phlomis tuberosa) újabb adatai a Hevesi-síkról. - Calandrella 7(1-2): 143.

Ambrus B. (1994): Macskahere (Phlomis tuberosa) újabb adatai a Hevesi-síkról. - Calandrella 8(1-2): 178.

BARÁTH Z. (1963). Növénytakaró vizsgálatok felhagyott szőlőkben. - Földrajzi Értesítő 12: 341-356.

BARINA Z. (2014): Piros kígyószisz - Echium maculatum Linnaeus 1759. - In: HARASZTHY L. (szerk.), Natura 2000 fajok és élőhelyek Magyarországon. Pro Vértes Közalapítvány, Csákvár, pp. 88-90.

BARTha D., Király G., Schmidt D., TiborCZ V., BARina Z., CSiky J., JAKAB G., LESKu B., SChmotZer A., VidéKi R., Vojткó A. \& ZólYomi Sz. (szerk.) (2015): Magyarország edényes növényfajainak elterjedési atlasza. Nyugat Magyarországi Egyetem Kiadó, Sopron, 329 pp.

BARTHA D. \& MÁTYÁs Cs. (1995): Erdei fa- és cserjefajok előfordulása Magyarországon. - Saját kiadás, Sopron, 223 pp.

BoRHIDI A. (1995): Social behaviour types, the naturalness and relative ecological indicator values of the higher plants in the Hungarian flora. - Acta Botanica Academiae Scientiarum Hungaricae 39: 97-181.

Boros Á. (1973): Florisztikai jegyzetek (1915-1971). - Mscr. MTM, Növénytár, Budapest

BudAI J. (1914): Adatok Borsod megye flórájához. - Magyar Botanikai Lapok 13: 312-326.

Buschmann F. (2013): A jászberényi Jász Múzeum növénygyüjteménye (Herbarium-collection in Musei Jazigiae Jászberényiensis). - Tisicum 22: 259-291.

Csathó A. I. (2009): A mezsgyék természetvédelmi jelentősége és védelmük időszerűsége. Természetvédelmi Közlemények 15: 171-181.

ENDES M. (1985): Ritkaságok és jellegzetességek: bepillantás a tiszai Alföld növényvilágába. - Jászsági Füzetek 7: 15 pp.

FEKETE G. (2011): Florisztika ma és holnap. - Kitaibelia 15(1-2): 13-23.

FEKETE G., Kun A. \& MolnÁR Zs. (1999): Chorológiai grádiensek a Duna-Tisza közi erdei flórában. Szárazgyepfajok lokális elterjedési típusai, chorológiai grádiense a Duna-Tisza közén. - Kitaibelia 4: 343-346.

Fekete G., Kun A. \& Molnár Zs. (2001): A Duna-Tisza közi erdei flóra. Chorológiai aspektusok. - In: Borhidi A. \& BotTA-DuKát Z. (szerk.), Ökológia az ezredfordulón. I. Koncepció, hosszú távú kutatások. MTA ÖBKI, Budapest, pp. 129-131.

FEKETE G., MolnÁR Zs., MAGYARI E., SOMODI I. \& VARGA Z. (2011): Egyediség, szabályszerűség és deviáció a Pannon régió vegetációjának példáján. - Botanikai Közlemények 98: 29-59.

FRISNYÁK G., CSÜLlÖG G. \& TAMÁS L. (2017): A kultúrtájak magterületei és terjedési irányai a Kárpátmedencében. - Történeti Földrajzi Közlemények 5(3-4): 62-75.

Garam É., Patay P. \& Soproni S. (2003): Sarmatisches Wallsystem im Karpatenbecken. - Régészeti Füzetek Ser. 2. No. 23, Magyar Nemzeti Múzeum 140 pp. 
Goмвосz E. (szerk.) (1945): Diaria Itinerum Pauli Kitaibelii I. II. - Természettudományi Múzeum, Budapest, 1083 pp.

HoRvÁth A. (2010): Validation of description of the xeromesophilous loess grassland association, Euphorbio pannonicae-Brachypodietum pinnati. - Acta Botanica Hungarica 52(1-2): 103-122.

JАКAB G. \& Tóth T. (2003): Adatok a Dél-Tiszántúl flórájának ismeretéhez. - Kitaibelia 8(1): 89-98.

JАКАB G. (2005): Adatok a Dél-Tiszántúl flórájának ismeretéhez II. - Flora Pannonica 3: 91-119.

JAKAB G. (2012): Horgas bogáncs (Carduus hamulosus). - In: JAKAB G. (szerk.): A Körös-Maros Nemzeti Park növényvilága. A Körös-Maros Nemzeti Park természeti értékei I. KMNP Igazgatóság, Szarvas, pp. 354-355.

JaKuCs P. (1961): Die phytozönologischen Verhältnisse der Flaumeichen-Buschwälder Südost-Mitteleuropas. - Akadémia Kiadó, Budapest, 314 pp.

Janka V. (1866): Neue Standorte ungarischer Pflanzen. - Österreichische botanische Zeitschrift 16(6): 169-172.

Jávorka S. (1935): Kitaibel herbáriuma IV. (Herbarium Kitaibelianum IV). - Annales Musei historiconaturalis hungarici 29: 55-102.

KANITZ Á. (1862): Reliquiae Kitaibelianae partim nunc primum publicatae ex manuscriptis Musei Nationalis hungarici. - Verhandlungen der Zoologisch-Botanischen Gesellschaft 12: 559-576.

KANITZ Á. (1863): Reliquiae Kitaibelianae partim nunc primum publicatae e manuscriptis Musei Nationalis hungarici. - Verhandlungen der Zoologisch-Botanischen Gesellschaft 13: 57-118.

KAPOCSI J., DOMÁN E., BíRó I., ForGÁch B. \& TóTH T. (1998): Florisztikai adatok a Körös-Maros Nemzeti Park illetékességi területéről. - Crisicum 1: 75-83.

Kevey B. (2001): Montán elemek a Baranyai-Dráva-sík erdeiben. - Kitaibelia 6(2): 299-321.

KEvEY B. (2017): Pótlások Magyarország edényes növényfajainak elterjedési atlaszához IV. - Kitaibelia 22(2): 358-382.

KEveY B. (2018): Pótlások Magyarország edényes növényfajainak elterjedési atlaszához VII. - Kitaibelia 23(2): 218-237.

KIRÁLY G. (2003): A magyarországi flóratérképezés módszertani alapjai. Útmutató és magyarázat hálótérképezési adatlapok használatához. - Flora Pannonica 1: 3-20.

KiRÁlY G. (szerk.) (2009): Új magyar füvészkönyv. Magyarország hajtásos növényei. Határozókulcsok. Aggteleki Nemzeti Park Igazgatóság, Jósvafő, 616 pp.

KIRÁlY G. \& KirÁlY A. (2018): Verbreitungsmuster von Waldpflanzen am Südwestrand der Kleinen Ungarischen Tiefebene. - Neilreichia 5: 19-110.

KIRÁlY G. \& KirÁLY A. (2018): Adatok és kiegészítések a magyar flóra ismeretéhez III. - Botanikai Közlemények 105(1): 27-96.

Korda M., Schmidt D., Vidéki R., HASZnosits Gy., Tiborcz V., CSisZÁr Á., ZAGYVAi G. \& BARThA D. (2017): A Gagea minima (L.) Ker Gawl. és a Dictamnus albus L. újrafelfedezése a Dél-Tiszántúlon, valamint további florisztikai adatok az Alföldről. - Kitaibelia 22(2): 304-316.

KUN A. \& BöLÖNI J. (2016): Felnyíló erdők lágyszárú fajainak védelmi lehetőségei - különös tekintettel az erdőssztyepp-erdők megőrzésére. - In: KoRDA M. (szerk.), Az erdőgazdálkodás hatása az erdők biológiai sokféleségére. Duna-Ipoly Nemzeti Park Igazgatóság, Budapest, pp. 89-106.

LESKu B. \& MolNÁR A. (2007): A Hortobágy növényritkaságai. - Daru füzetek, Hortobágyi Nemzeti Park Igazgatóság, Debrecen, 120 pp.

LőKös L. (szerk.) (2001): Diaria Itinerum Pauli Kitaibelii III. - Magyar Természettudományi Múzeum, Budapest, $459 \mathrm{pp}$.

Lukács B., Gulyás G., Horváth D., Hődör I., Schmotzer A., Sramkó G., TAKÁcs A. \& Molnár A. (2017): Florisztikai adatok a Tiszántúl középső részéről. - Kitaibelia 22(2): 317-357.

MARSCHALl Z. \& VojTKó A. (1989): Az Eger-patak árterének növényzete Füzesabony közelében. - Acta Academiae Paedagogicae Agriensis 19(9): 187-196.

MolnÁr A. (2005): Adatok a Hortobágy flórájának ismeretéhez. - In: Molnár A. (szerk.), Hortobágyi mozaikok. Hortobágyi Nemzeti Park Igazgatóság, Debrecen, pp. 41-71.

Molnár Cs., Lengyel A., Molnár V. A., NAgy T., Csábi M., SÜveges K., Lengyel-Vaskor D., Tóth Gy. \& TaKács A. (2016): Pótlások Magyarország edényes növényfajainak elterjedési atlaszához II. - Kitaibelia 21(2): 227-252.

Molnár Cs., Haszonits Gy., Malatinszky Á., KovÁcs G. K., Kovács G., Nagy T., Molnár V. A. \& TakÁcs A. (2017): Pótlások Magyarország edényes növényfajainak elterjedési atlaszához III. - Kitaibelia 22(1): 122-146. MolnÁr V. A. (szerk.) (2011): Magyarország orchideáinak atlasza. - Kossuth Kiadó, Budapest, 504 pp. 
MolnÁr Zs. (2008): A Duna-Tisza köze és a Tiszántúl növényzete a 18-19. század fordulóján I.: Módszertan, erdők, árterek és lápok. - Botanikai Közlemények 95(1-2): 11-38.

MolNÁR Zs. \& Kun A. (szerk.) (2000): Alföldi erdőssztyepp-maradványok Magyarországon. - WWF füzetek 15. WWF Magyarország, Budapest, $56 \mathrm{pp}$.

NiKLFELD H. (1971): Bericht über die Kartierung der Flora Mitteleuropas. - Taxon 20: 545-571.

PAPP L. \& DUDÁs M. (1989): Adatok a Közép-, a Dél-Nyírség és környékének botanikai értékeiről II. Calandrella 3(2): 13-32.

PELLE B.né (1975): Heves megye földrajzi nevei II. A füzesabonyi járás. - Magyar Nyelvtudományi Társaság Kiadványai 144. Budapest, 177 pp.

Pelle B.né (1980): Heves megye földrajzi nevei III. A hevesi járás. - Magyar Nyelvtudományi Társaság Kiadványai 145. Budapest, 192 pp.

PIFKó D. (2007): Cytisus-taxa of Pál Kitaibel. - Studia Botanica Hungarica 38: 11-32.

Schmotzer A. (2014): A Hevesi-sík flórakutatásának eredményei. - In: Schmotzer A. (szerk.), Szikfok. Délhevesi tanulmányok. Bükki Nemzeti Park Igazgatóság, Eger pp. 25-68.

Schmotzer A. (2015): Ceratocephala testiculata (Crantz) Roth és további adatok a Bükkalja flórájához. Kitaibelia 20(1): 81-142.

SCHMOTZER A. \& VIDRA T. (1998): Flórakutatás a Monor-Irsai-dombság löszvidékén. - Kitaibelia 3(2): 321328.

SCHMOTZER A. \& TAKÁcs A. (2014): Janka-tarsóka - Thlaspi jankae Kerner, 1867. - In: HARASZTHy L. (szerk.), Natura 2000 fajok és élőhelyek Magyarországon. Pro Vértes Közalapítvány, Csákvár, pp. 55-57.

Simon T. (1950): Montán elemek az Északi Alföld flórájában és növénytakarójában. - Annales Biologicae Universitatis Debreceniensis 1(7): 146-174.

Simon T. (1951): Montán elemek az Észak-Alföld flórájában és növénytakarójában, II. - Annales Biologicae Universitatum Hungariae 1: 303-310.

Simon T. (1952): Montán elemek az Északi-Alföld flórájában és növénytakarójában. III. - Annales Biologicae Universitatum Hungariae 2: 279-286.

SOMLYAY L. (2009): A Budai-hegység florisztikai növényföldrajzának fő vonásai. - Kitaibelia 14(1): 35-68.

Soó R. \& MáTHÉ I. (1938): A Tiszántúl flórája. - Magyar Flóraművek 2: 1-192.

Soó R. (1973): A magyar flóra és vegetáció rendszertani-növényföldrajzi kézikönyve. (Synopsis systematicogeobotanica Florae Vegetationisque Hungariae). - Akadémiai Kiadó, Budapest, vol. V. 724 pp.

SRAMKó G., MAGOS G., MolnÁR Cs. \& URBÁN L. (2008): Adatok a Mátra és környéke edényes flórájának ismeretéhez. - Kitaibelia 13(1): 74-93.

SZUJKó-LACZA J. (1984): The flora of the Kerecsendi berek forest. - Studia botanica hungarica 17: 23-39.

SzUjKó-LACZA J., FeKeTE G., Kováts D., SzABó L. \& Siroki Z. (1982): The vascular plants of the Hortobágy National Park. - In: SzujKó-LACZA J. (ed.), The Flora of the Hortobagy National Park. Akadémiai Kiadó, Budapest, pp. 105-169.

TAKÁCS A. \&ZsóLYOMI T. (2010): Adatok a Taktaköz flórájának ismeretéhez. - Kitaibelia 15(1-2): 25-34.

TAKÁCs A., NAgY T., FeKeTE R. Lovas-Kiss Á., LjubKa T., LÖKI V., LisZTeS-Szabó Zs. \& MolnÁr V. A. (2014a): A Debreceni Egyetem Herbáriuma (DE) I.: A „Soó Rezső Herbárium”. - Kitaibelia 19(1): 142-155.

TAKÁCS A., ZÁKÁNY A, GulYás G., Koscsó J. \& SRAmKó G. (2014b): Florisztikai adatok a Tiszántúl északi pereméről. - Kitaibelia 19(2): 275-294.

VojTKó A. (1994): Adatok a Bükk hegység flórájához. - Botanikai Közlemények 81(2): 165-175.

Vојтко́ A. (2001): A Bükk hegység flórája. - Sorbus 2001, Eger, 340 pp.

Zólyomi B. (1957): Der Tatarenahorn-Eichen-Lösswald der Zonalen Waldsteppe (Acereto TatariciQuercetum). - Acta botanica hungarica 3: 401-429.

ZóLYOMI B. (1969): Földvárak, sáncok, határmezsgyék és a természetvédelem. - Természet Világa 100: $550-553$.

Zólyomi B. \& FeKete G. (1994): The Pannonian loess steppe: differentiation in space and time. - Abstracta Botanica 18: 29-41.

Beérkezett / received: 2019. 02.19. • Elfogadva / accepted: 2019. 03. 17. 